\title{
Paleornithology of St. Helena Island, South Atlantic Ocean
}

\section{STORRS L. OLSON}




\title{
SERIAL PUBLICATIONS OF THE SMITHSONIAN INSTITUTION
}

The emphasis upon publications as a means of diffusing knowledge was expressed by the first Secretary of the Smithsonian Institution. In his formal plan for the Institution, Joseph Henry articulated a program that included the following statement: "It is proposed to publish a series of reports, giving an account of the new discoveries in science, and of the changes made from year to year in all branches of knowledge." This keynote of basic research has been adhered to over the years in the issuance of thousands of titles in serial publications under the Smithsonian imprint, commencing with Smithsonian Contributions to Knowledge in 1848 and continuing with the following active series:

\author{
Smithsonian Annals of Flight \\ Smithsonian Contributions to Anthropology \\ Smithsonian Contributions to Astrophysics \\ Smithsonian Contributions to Botany \\ Smithsonian Contributions to the Earth Sciences \\ Smithsonian Contributions to Paleobiology \\ Smithsonian Contributions to Zoology \\ Smithsonian Studies in History and Technology
}

In these series, the Institution publishes original articles and monographs dealing with the research and collections of its several museums and offices and of professional colleagues at other institutions of learning. These papers report newly acquired facts, synoptic interpretations of data, or original theory in specialized fields. These publications' are distributed by mailing lists to libraries, laboratories, and other interested institutions and specialists throughout the world. Individual copies may be obtained from the Smithsonian Institution Press as long as stocks are available.

\author{
S. Dillon Ripley \\ Secretary \\ Smithsonian Institution
}


SMITHSONIAN CONTRIBUTIONS TOPALEOBIOLOGY - NUMBER 23

\section{Paleornithology of St. Helena Island, South Atlantic Ocean}

Storrs L. Olson

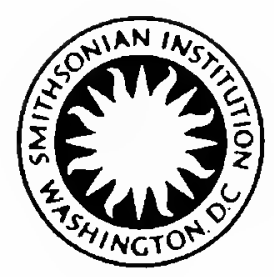

SMITHSONIAN INSTITUTION PRESS

City of Washington

1975 


\begin{abstract}
A B S T R A C T
Olson, Storrs L. Paleornithology of St. Helena Island, South Atlantic Ocean. Smithsonian Contributions to Paleobiology, number 23, 49 pages, 10 figures, 6 plates, 8 tables, 1975.-The present avifauna of St. Helena is a very depauperate one, many species of birds having been extirpated since man's discovery of the island in 1502. The great extent of this extinction was confirmed by a study of over 4600 specimens of fossil and subfossil bird bones, representing 21 species, collected from rich deposits on the island. These deposits vary in age and fall roughly into three groups, the oldest of which extends well back into the Pleistocene, the youngest of which is very recent, and the third is intermediate. The deposits yielded the remains of the following species, six of which are here described as new: Procellariidae-Pterodroma rupinarum, new species, Bulweria bifax, new species, Puffinus pacificoides, new species, $P$. griseus, P. lherminieri; Oceanitidae-Pelagodroma marina, Oceanodroma castro; PhaethontidaePhaethon aethereus; Sulidae-Sula sula, S. dactylatra; Fregatidae-Fregata ariel trinitatis, F. minor; Rallidae-Atlantisia podarces, Porzana astrictocarpus; Charadriidae-Charadrius sanctaehelenae; Laridae-Larus sp., Gygis alba, Sterna fuscata; Columbidae-Dysmoropelia dekarchiskos, new genus and species; Cuculidae-Nannococcyx psix, new genus and species; Upupidae-Upupa antaios, new species. Pterodroma rupinarum and Puffinus pacificoides belong to species-groups that presently occur in the Indo-Pacific but not in the Atlantic; no gadfly-petrel of the size of Bulweria bifax is found in the Atlantic today. Puffinus griseus and Larus sp. are thought merely to have been vagrants on St. Helena. The pigeon and the hoopoe were both large and probably flightless. Differences in the composition and relative abundance of species between the deposits of different age indicate that the marine environment at St. Helena became progressively more tropical late in the Pleistocene. This resulted in great decreases in, or even extinction of, some of the species of Procellariiformes and in the appearance later in the fossil record of more purely tropical seabirds such as boobies, frigatebirds, and Sooty Terns.
\end{abstract}

OfFICIAL PUBLICATION DATE is handstamped in a limited number of initial copies and is recorded in the Institution's annual report, Smithsonian Year. SI Press NUMBer 5210. Series cover design: The trilobite Phacops rana Green.

Library of Congress Cataloging in Publication Data

Olson, Storrs L.

Paleornithology of St. Helena Island, South Atlantic Ocean.

(Smithsonian contributions to paleobiology, no. 23)

Supt. of Docs. no.: SI 1.30:23

1. Birds, Fossil. 2. Paleontology-Pleistocene. 3. Paleontology-Recent. 4. Birds, Extinct. 5. Paleontology-St. Helena. I. Title. II. Series: Smithsonian Institution. Smithsonian contributions to paleobiology, no. 23.

QE701.S56. no. 23 [QE872] $560^{\prime} .8 \mathrm{~s} \quad\left[568^{\prime} .2^{\prime} 0973\right] \quad 74-14890$

For sale by the Superintendent of Documents, U.S. Government Printing Office Washington, D.C. 20402 Price $\$ 1.35$ 


\section{Contents}

Introduction

Acknowledgments $\ldots \ldots . \ldots \ldots \ldots . \ldots \ldots$

A Physical and Historical Sketch of St. Helena $\ldots \ldots \ldots \ldots . \ldots . \ldots$

History of Paleornithology on St. Helena $\quad \ldots \ldots . . .6$

The Fossil Deposits ... $\ldots \ldots \ldots \ldots \ldots$

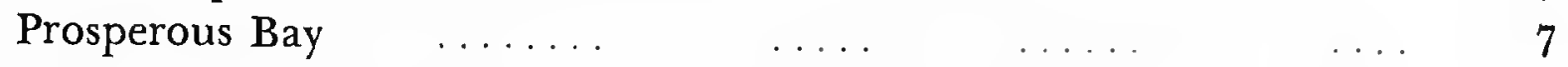

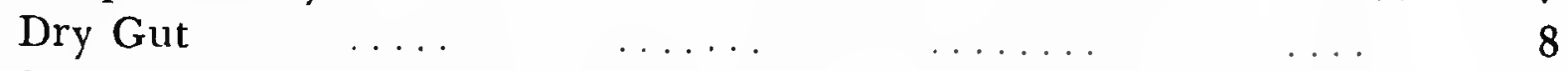

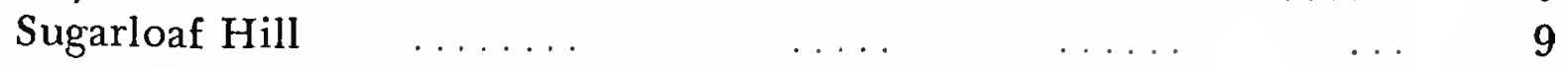

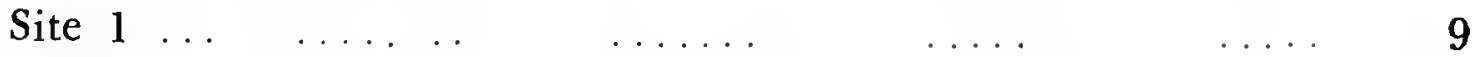

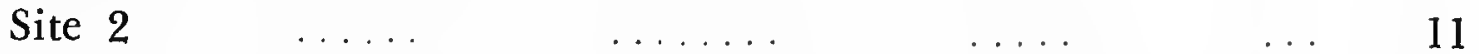

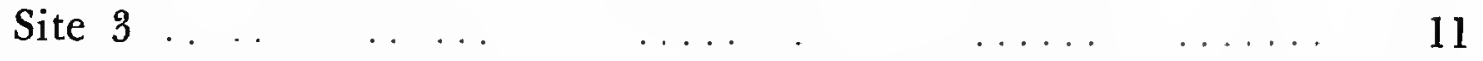

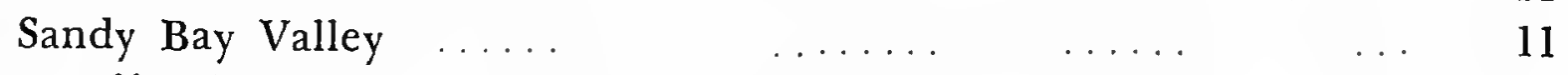

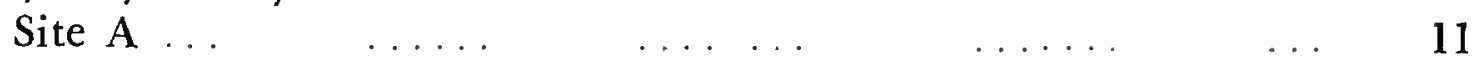

Site $\mathrm{B} \quad \ldots \ldots \ldots 11$

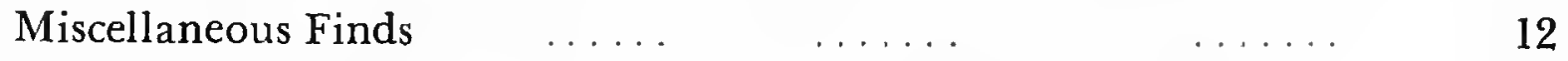

Age of the Deposits $\quad \ldots \quad \ldots \quad \ldots \ldots \ldots 12$

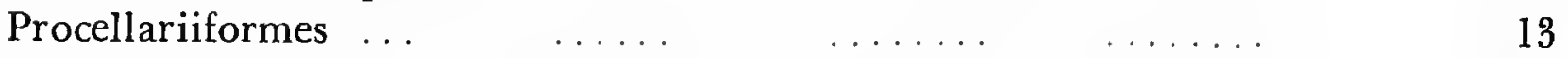

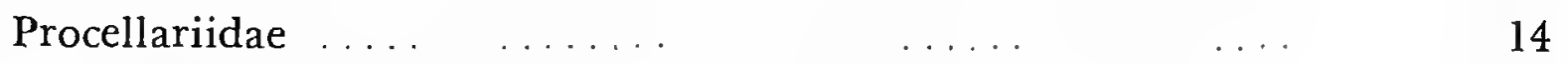

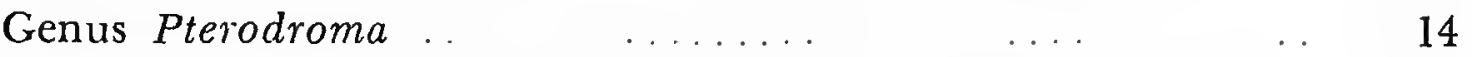

Pterodroma rupinarum, new species ....... ..... 14

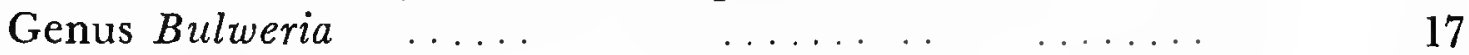

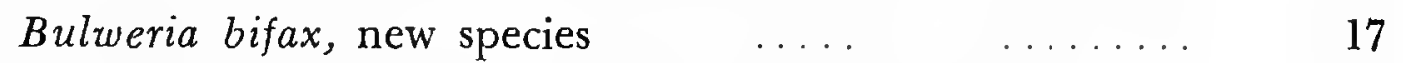

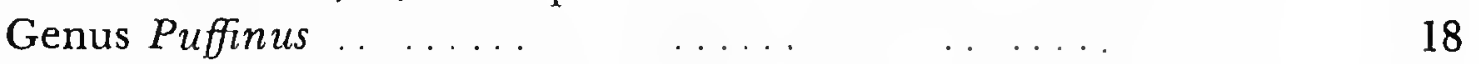

Puffinus pacificoides, new species ..... ........ 18

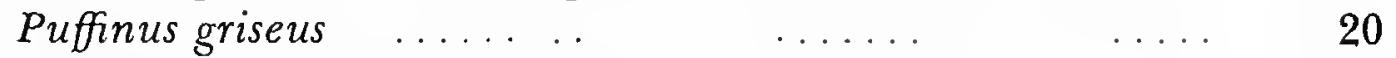

Puffinus lherminieri $\quad \ldots . . \quad \ldots . . . .20$

Oceanitidae $\quad \ldots \ldots . \ldots \ldots . \ldots .21$

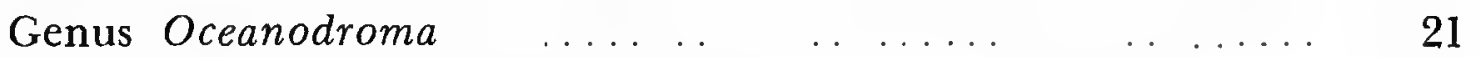

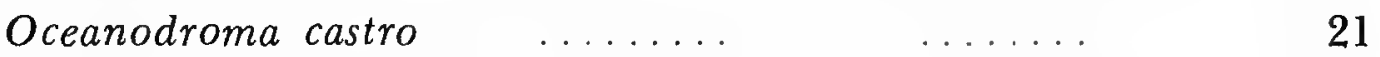

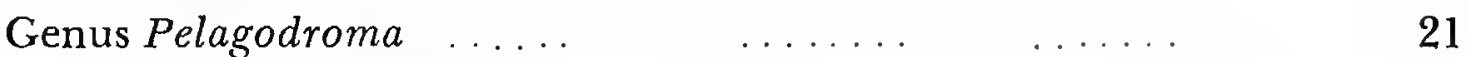

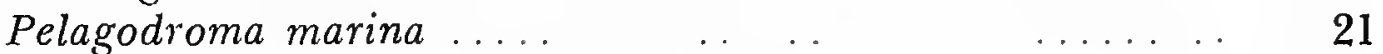

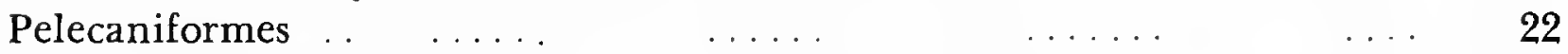

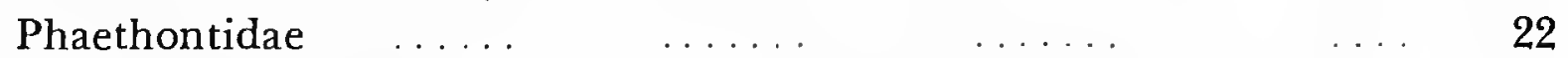

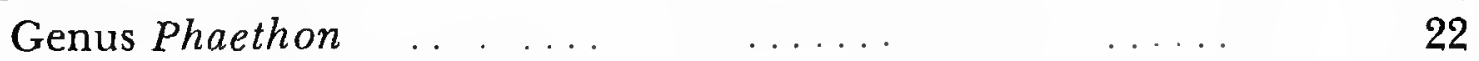

Phaethon aethereus ...... $\quad \ldots \ldots \ldots . \ldots . \ldots 2$

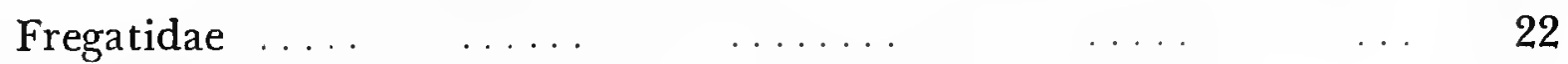

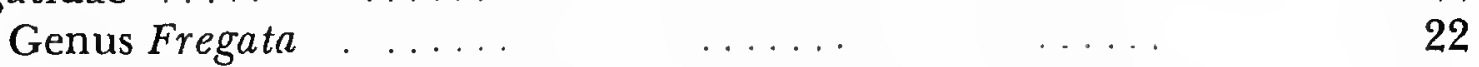

Fregata ariel trinitatis ... $\quad \ldots \ldots \ldots . \quad \ldots \quad 22$

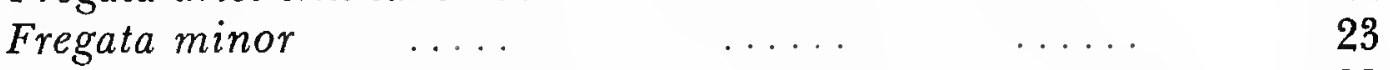

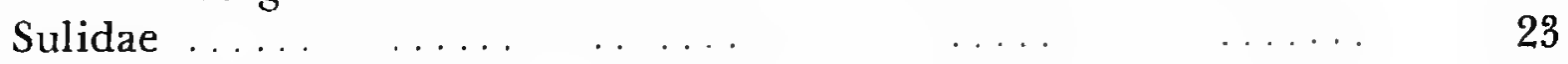

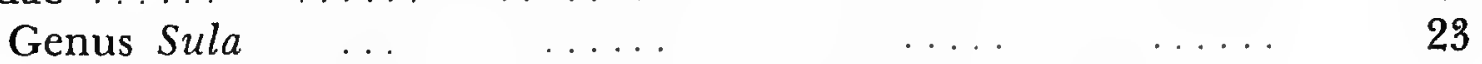

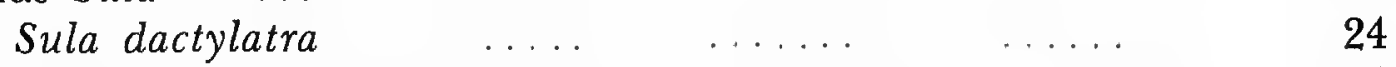

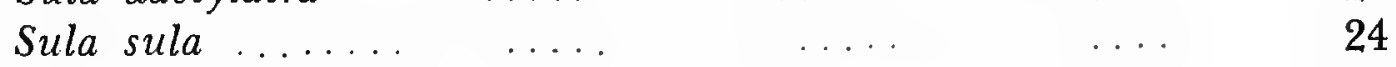

$\begin{array}{llllll}\text { Sula leucogaster } & \ldots & \ldots & \ldots & \ldots & 24\end{array}$

iii 
Gruiformes . . . . . . .

Rallidae . $\quad \ldots \ldots \ldots \ldots \ldots$............ 24

Genus Atlantisia $\ldots \ldots \ldots \ldots \ldots \ldots$.......... 24

Atlantisia podarces $\quad \ldots \ldots \ldots \ldots \ldots 24$

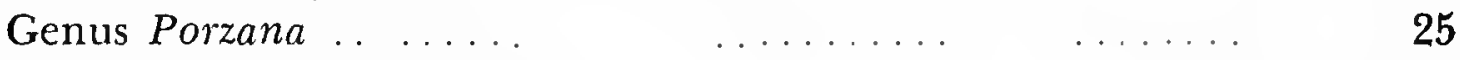

Porzana astrictocarpus $\quad \ldots \ldots \ldots \ldots \ldots \ldots$

Genus Gallinula ... _......... . . 25

Gallinula chloropus $\quad \ldots \ldots \ldots \ldots \ldots . \ldots 25$

Charadriiformes ................. ... 25

Charadriidae .................. .... 25

Genus Charadrius ..... ............. 25

Charadrius sanctachelenae $\quad \ldots \ldots \ldots \ldots \ldots 25$

Laridae .... .............. ...

Genus Larus _ . . . . . . . . . . . $\quad 27$

Larus sp. . $\quad \ldots \ldots \ldots \ldots \ldots . \ldots . \ldots . \ldots 27$

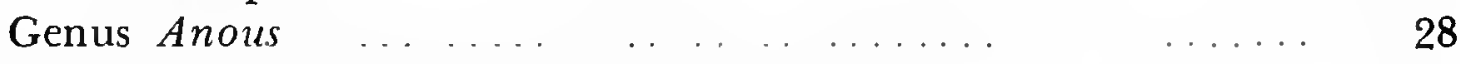

Anous stolidus and Anous tenuirostris ......... 28

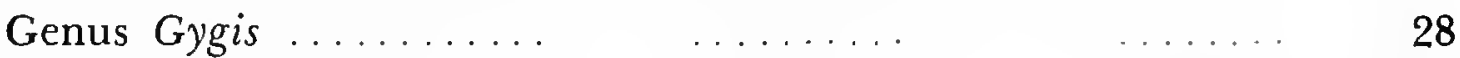

Gygis alba ...... . . . . . . . . . . . . $\quad 28$

Genus Sterna . . . $\quad \ldots \quad \ldots \ldots \ldots$

Sterna fuscata ... . $\quad \ldots \ldots \ldots \ldots \ldots \ldots$

Columbiformes $\ldots \ldots \ldots \ldots \ldots \ldots \ldots \ldots 28 \ldots \ldots . \ldots \ldots$

Columbidae $\ldots \ldots \ldots \ldots \ldots \ldots \ldots \ldots$

Genus Dysmoropelia, new genus ............. ... 29

Dysmoropelia dekarchiskos, new species ..... ..... 29

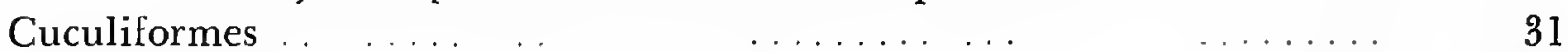

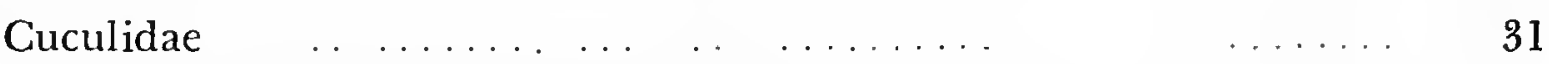

Genus Nannococcyx, new genus $\ldots \ldots \ldots \ldots \ldots \ldots$

Nannococcyx psix, new species ..................... 32

Coraciiformes $\quad \ldots \ldots \ldots \ldots \ldots \ldots \ldots . \ldots \ldots$

Upupidae $\quad \ldots \ldots \ldots \ldots \ldots \ldots$

Genus $U p u p a \quad \ldots \ldots \ldots \ldots \ldots \ldots \ldots \ldots$

Upupa antaios, new species $\quad \ldots \ldots \ldots \ldots . \ldots . \ldots . \ldots 2$

Passeriformes $\ldots \ldots \ldots \ldots \ldots \ldots \ldots$

Discussion $\quad \ldots \ldots \ldots \ldots \ldots \ldots$

Epilogue $\ldots \ldots \ldots \ldots \ldots$

Literature Cited . . . . . . . . ....... . . 41

Plates .. . . . .... . . . . . . . . $\quad \ldots .44$ 


\title{
Paleornithology of St. Helena Island, South Atlantic Ocean
}

\author{
Storrs L. Olson
}

\section{Introduction}

St. Helena appears to have extensive deposits containing fossil or subfossil bird bones. It is a sad and scandalous fact that no proper study of these bones has ever been undertaken.

GEORGE EVELYN HUTCHINSON (1950:314)

The remote island of St. Helena, isolated in a virtually unbroken expanse of the South Atlantic Ocean, is renowned principally for having been the last place of exile of Emperor Napoleon I. From a political point of view, the period of its occupancy by the vanquished conqueror was the high point of the island's history. But from a biological standpoint, the island had reached its zenith some centuries before. By the time Napoleon and his entourage first landed on St. Helena in 1815, there was, for all practical consideration, nothing left of the island's original vegetation. Longwood, where Napoleon eventually resided and so named for the great forest that had once stood there, was already a barren, wind-swept plain.

Had the unhappy Frenchmen troubled to notice any birds, they would have seen finches introduced from Africa, Madagascar, and Java; mynas from India; and doves from Malaya. Only the most observant would have noted the little plover, Charadrius sanctaehelenae-the only surviving native land bird. At sea and around the rugged coast there were only four species of terns, a tropicbird, a storm-petrel, and perhaps an occasional booby.

Storrs L. Olson, National Museum of Natural History, Smithsonian Institution, Washington, D.C. 20560.
These few species form but a pitiful remnant of a much larger avifauna that once inhabited the island. Fully a dozen species have disappeared forever from the face of St. Helena, most of them since the coming of man. There apparently is no historical record of any of these species except the frigatebirds, all the rest being known only from the bone deposits alluded to in the opening quotation. It is hoped that the present paper will in some measure rectify the lamentable lack of knowledge of these bones that so scandalized G. E. Hutchinson 25 years ago.

ACKNOWLEDGMENTS.-This work is a continuation of studies on material collected by me in 1971, some of which was used in preparation of my report on South Atlantic rails (Olson, 1973). The acknowledgments made in that paper in large part apply here as well. I wish to reiterate my gratitude to all those who made my work in the South Atlantic not only possible, but enjoyable.

In the course of preparing this paper I have frequently relied on specimens, often rare or unique, borrowed through persons in other institutions-I deeply appreciate their consideration: David W. Snow and Cyril Walker, British Museum (Natural History) (BMNH); Christian Jouanin, Museum d'Histoire Naturelle de Paris; Raymond A. Paynter, Jr., Museum of Comparative Zoology (MCZ); Dean Amadon, American Museum of Natural History (AMNH); Eleanor Stickney and Fred Sibley, Yale Peabody Museum (YPM); Pierce Brodkorb, University of Florida. Arthur Loveridge very kindly supplied information on the collections 


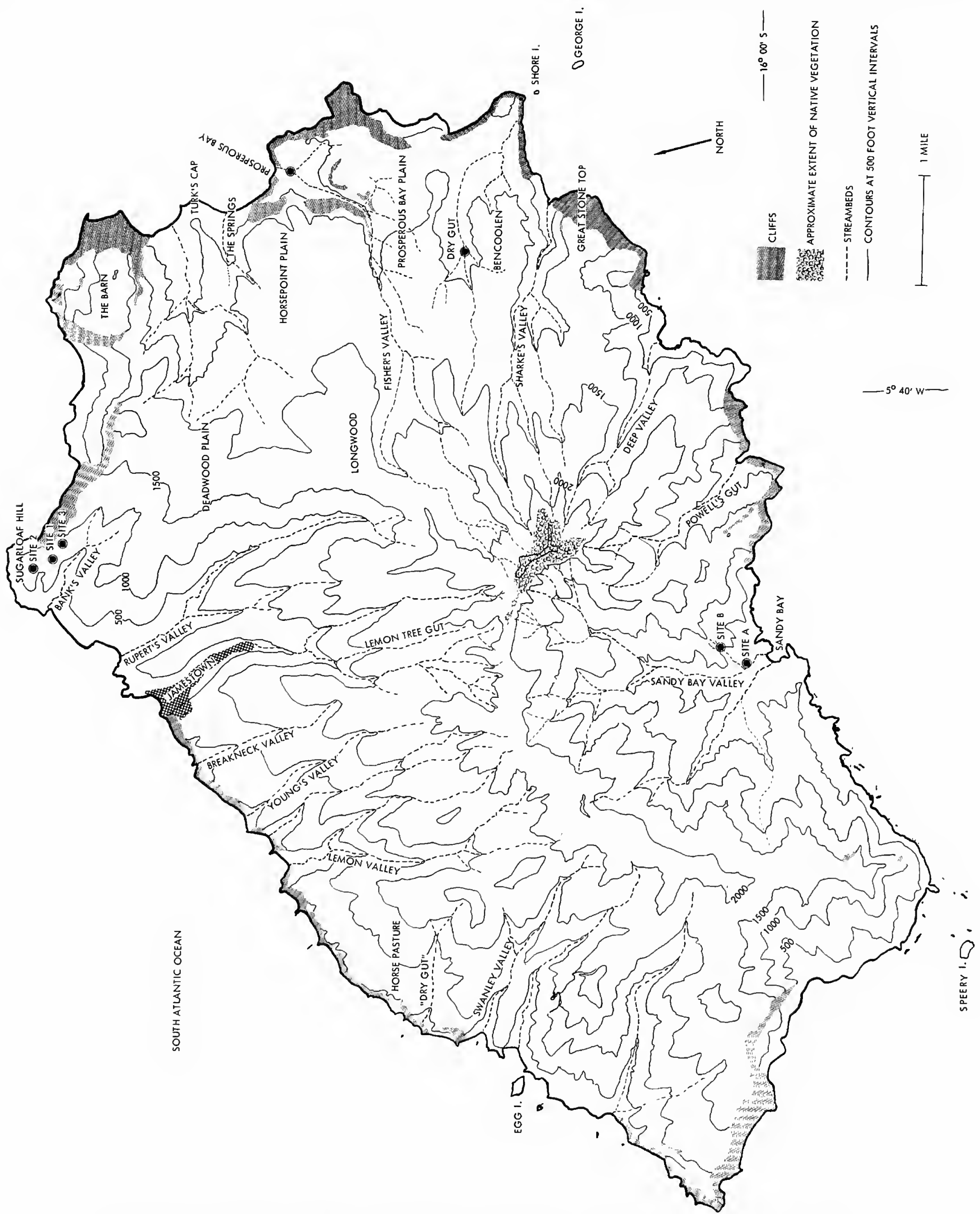

Figure 1.-Map of St. Helena showing collecting localities (solid circles) and some of the principal features of the island. Streambeds indicate both continual and intermittent streams. 
of fossils that he and J. W. Bailey made on St. Helena. M. P. Stuart Irwin donated a skeleton of Charadrius pecuarius. Richard L. Zusi was most helpful in preparing and discussing X-ray photographs used in this study. I have benefitted from conversations with Roger Clapp, John Farrand, Jr., Warren King, and George Watson, all of whom have commented on portions of early drafts of the manuscript. Extensive criticisms of an early draft were provided by N. P. Ashmole and W. R. P. Bourne, with the result, hopefully, that the present effort is an improvement. The effort expended by P. E. Hare of the Geophysical Laboratory, Carnegie Institution, in establishing the relative ages of the bones from various deposits on St. Helena is very much appreciated. The photographs are by Victor E. Krantz. Lastly, the final draft of the manuscript was subjected to the careful scrutiny and erudite commentary of John Farrand, Jr., for which $I$ am exceedingly obliged.

\section{A Physical and Historical Sketch of St. Helena}

Daly (1927:3I) has made the observation that St. Helena and the still smaller island of Ascension form "the only dry land in an area of $15,000,000$ square kilometers, or three per cent of the earth's surface." St. Helena is $122 \mathrm{~km}^{2}$ (47 sq $\mathrm{mi}$ ) in area and lies between latitudes $15^{\circ} 54^{\prime}$ and $16^{\circ} 01^{\prime} \mathrm{S}$ and longitudes $5^{\circ} 37^{\prime}$ and $5^{\circ} 47^{\prime} \mathrm{W}$, at a distance of $1913 \mathrm{~km}$ from Africa, $3284 \mathrm{~km}$ from South America, and $1296 \mathrm{~km}$ from Ascension Island, which is the nearest land.

St. Helena attains an elevation of $823 \mathrm{~m}$ (2685 feet) above sea level and stands on a volcanic pile rising more than $5 \mathrm{~km}$ from the ocean floor. It forms part of the mid-Atlantic Ridge but is displaced considerably to the east of the midline of the ridge. An age of $14.3 \pm 1.0$ million years has been determined for the oldest rocks on the island (Baker, 1970). The effects of erosion are awesome and the island is characterized by sheer sea cliffs of imposing height and many deep precipitous valleys (Figure 1). Beaches are restricted to the mouths of a few of these valleys.

The island lies in the region of southeasterly tradewinds that blow with great strength and constancy (Figure 2). Asymmetry of ancient cinder cones establishes that these winds were in effect at least as early as the late Miocene (Baker, 1970).

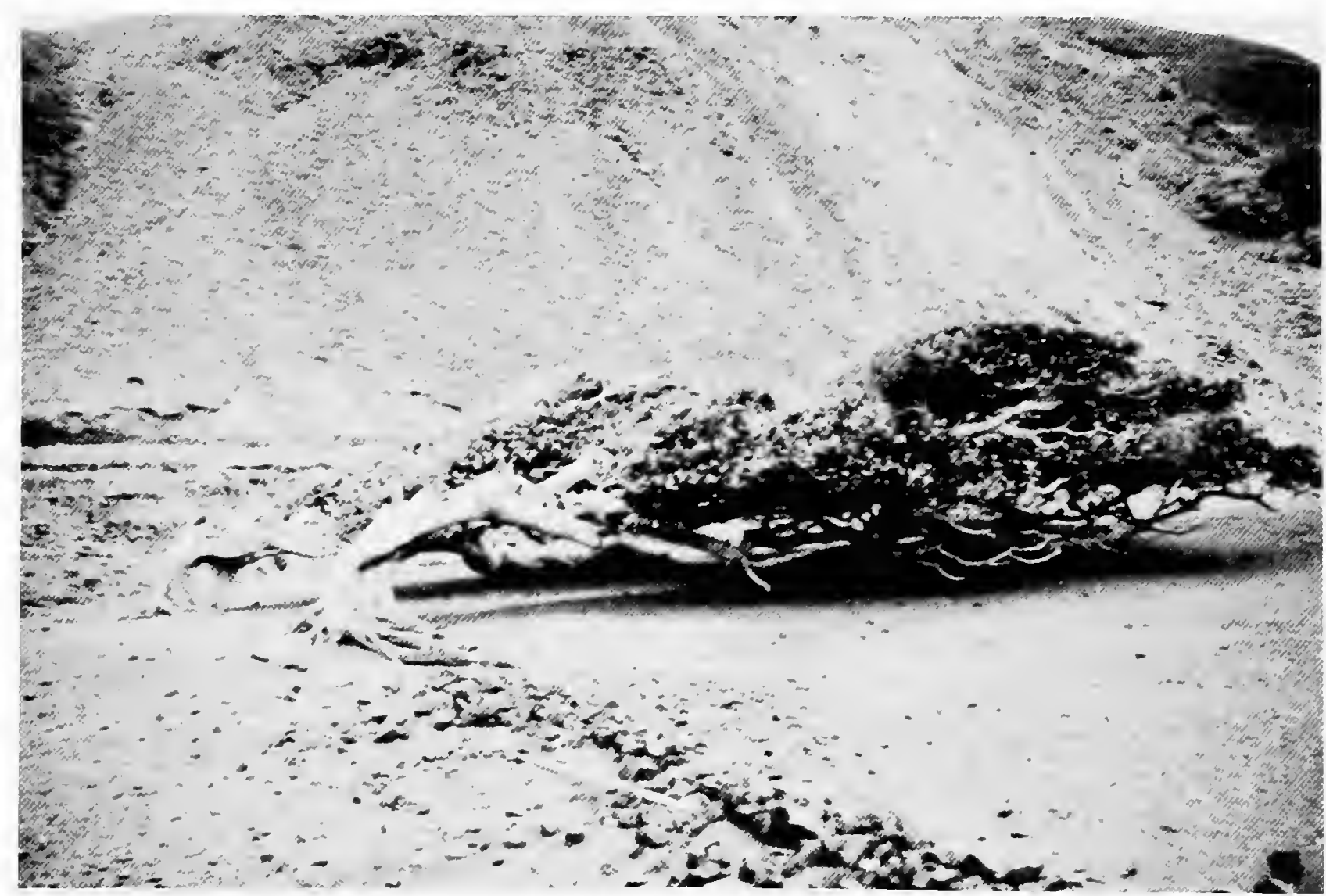

Figure 2.-Large fig trees in Sandy Bay Valley showing the effects of the constant southeast winds. 
Climatic conditions are generally mild, but vary considerably with elevation. Temperatures at sea level range from $20^{\circ}$ to $32^{\circ} \mathrm{C}$ in summer and $14^{\circ}$ to $21^{\circ} \mathrm{C}$ in winter, while temperatures in the high central area of the island average $5^{\circ}$ to $6^{\circ} \mathrm{C}$ cooler (Leleup, 1970). Precipitation likewise varies with season and altitude; Jamestown, at sea level, receives on the average a little over $200 \mathrm{~mm}$ of rain per year, while the upper parts of the island may receive more than four times that amount. Winter days in the areas above $450 \mathrm{~m}$ are often overcast and rainy, and at times "on the mountaintops, by reason of the chilling winds, it is wondrous cold" as François Pyrard observed in June 1610 (Gray, 1890:300). Many freshwater streams arise in the highlands as a result of the heavy rainfall.

The disparity in rainfall between the upper and lower parts of the island has produced two distinct physiographic zones-a wet, well-vegetated area above $450 \mathrm{~m}$, and an arid, poorly vegetated zone below that elevation. Hooker (cf. Melliss, 1875: 221) stated that the island when discovered "was entirely covered with forests, the trees drooping over the tremendous precipices that overhang the sea." The accuracy of this impression has been questioned, however (Benson, 1950). The presence of an endemic plover and several endemic insects adapted to the barren arid portions of the island are, as Decelle (1970) notes, strong indications that these conditions existed for some time in the past. Nevertheless, St. Helena had, at least inland, a rich, dense forest cover. This is now almost entirely gone.

The discovery of St. Helena was made on 21 May 1502 by the Portuguese admiral João da Nova Castella (Gosse, 1938:2). From the standpoint of the native flora and fauna, the subsequent history of the island was almost entirely one of destruction. Glimpses into the man-made changes wrought on St. Helena are afforded by the scattered accounts of early navigators and travelers. Unfortunately, there seems to be no written record made of any of the native land birds other than the Wirebird (Charadrius sanctachelenae), the only endemic species that still exists on the island.

The first human inhabitant of St. Helena was a Portuguese officer, Fernão Lopes, who had been mutilated as punishment for transgressions committed against Afonso Albuquerque in India, and in 1513 managed to escape into the wilderness of St. Helena from a vessel bound for Lisbon.

As time went on, this man used to show himself and converse with the people of the ships which passed by, and all gave him things to plant and to sow, so that he cultivated a great many gourds, pomegranates, and palm trees, and kept ducks, hens, sows, and she goats with young, all of which increased largely, and all became wild in the wood (Birch, 1880: xxxvii).

Thus, the introduction of elements as destructive as hogs and goats took place not later than the early part of the 16 th century. In 1536 it was recorded that "there are also wild pigs and goats on this island. There is a Portuguese hermit [Lopes] there, but no other people whatever" (Markham, C. R., 1911:83). At some time before 1557, several slaves escaped onto St. Helena and provisioned themselves with "half-wild cattle, goats and swine, as well as plantations of vegetables and fruit" (Gosse, 1938:11).

Introductions of birds must also have taken place at an early date. In June of 1588, Captain Thomas Cavendish found several introduced species, among which can be identified Chukar Partridge (Alectoris chukar), Ring-necked Pheasant (Phasianus colchicus), and guineafowls (Numida sp.); the first two of these are still to be met with on the island. Cavendish also recorded

thousands of goats, . which are very wild: you shall see one or two hundred of them together, and sometimes you may behold them going in a flock almost a mile long. . . We took and killed many of them for all their swiftness, for there be thousands of them upon the mountains . . Here are in like manner great store of swine which be very wild and very fat, and of a marvellous bigness (Gosse, 1938:18).

In May of the following year (1589) van Linschoten found the island "so full of Goates, Buckes, wild Hogges, Hennes, Partridges, and Doves, by thousands, so that any man that will, may hunt and take them ... and they may kill them with stones and staves, by reason of the great numbers of them" (Thiele, 1885:225).

In April 1593 there was an "abundance of goates and hogs, and great plentie of partridges, guiniecocks, and other wilde foules" (Markham, C. R., $1877: 18)$; in May 1600 "great abundance of Goates, and some store of Swine" (Sinclair, 1902:lxxv); and in February 1603 "great stoare of goats and hogges and partridges," but at this time they were "not to be gotten without great labour and paines, 
for they are wilde and the iland full of great high hilles" (Foster, 1940:139-140).

The navigator John Davis in April 1606 reported: "In the said Iland are many wilde Swine and Goates. There are also great store of Partridges, Turkie Cockes and Ginnie Hennes. This Iland is not inhabited" (Markham, A. H., 1880: 184). In June of 1610 François Pyrard recorded "many sorts of animals, such as goats, hogs, white and red partridges, wood-pigeons, turkeys, pheasants, etc." and "were it not that the vast number of goats and pigs, by trampling, wear the hillsides into paths, it would be impossible to ascend, and still more to descend" (Gray, 1890:299-300).

Thirty hogs were taken by Thomas Best's company in 1614 and he speculated that "if we had laid ourselves out for the purpose, I daresay we might have got two hundred hogs besides many goats" (Gosse, 1938:29). John Jourdain in April 1617 found a letter from "Captaine Keelinge," who in February had "taken good store of hoggs, goats and fishe" but because he "had taken all the hogges" Jourdain lamented that "in five dayes that wee stayed wee could kill butt one hogge and four goates .... And the goates are soe wild that there is greate craft in catchinge of them" (Foster, 1905: 344-345). Jon Olafsson reported "great herds of swine in the uplands, and in the valleys" in 1625 (Gosse, 1938:39).

Of particular interest are the observations of the astute diarist Peter Mundy. In 1634 he found that the island was "abounding in Goates, of whome you may see many flocks of great numbers every Foote. Also aboundance of Hoggs, store of little speckled ginney Henns, partridges and Pigeons .... Heere are also doggs and Catts (runne away) of whome our Companie killed divers .... In all wee caught about 130 or 140 Goates, hoggs, kidds and piggs" (Temple, 1914:330,332). On returning in 1638 there were, according to Mundy, in addition to goats and hogs, "Dogges here great store, and some cattes, guinny hens .. Partridges . . . Pidgeons and a smalle land Foule and butt only that one kind here to be seen" (Temple, 1919:413). By 1656 conditions had changed, for Mundy and his company did not

see soe much as one goate: supposed to bee devoured by dogges, which have mightily encreased here. Hogges there are many, having seene 25 or 30 in a heard together, little and great . Guinny henns . partridges, and pidgeons, great store, having seene flockes of each: allso a smalle land foule, somwhatt like a larcke in collour, shape, flightt and note. Itt would run like a lapwing (Temple and Anstey, 1936:79-80).

The last is certainly a reference to the endemic plover.

It is not known when rats (Rattus) first made their appearance at St. Helena, but it was probably soon after its discovery. In 1666 "there was nothing obnoxious to the amenities of life except vast quantities of rats, on which the Governor wages a sanguinary war" (Gosse, 1938:54). Wild rats were a "sorely vexatious" and "mischievous vermin" in 1682 (Gosse, 1938:79). In 1698 Leguat judged that "the few Inhabitants of this Island might live much better, or more at ease, were it not for a prodigious number of Rats that spoil their Fruit and Corn" (Oliver, 1891:299). Much the same situation prevailed in 1717 when "the rats ate up all the grain as soon as it was sown, and this in spite of 'vast numbers of cats, that went away from the houses, and became wild, living among the rocks, where they find good prog, feeding on young partridges, so that they became as great a plague as the rats'" (Gosse, 1938:140). By this time it is virtually certain that, with the exception of frigatebirds, those native birds that do not remain on St. Helena today had long since vanished.

Rats have remained a scourge up to the present. Mice (Mus musculus) are extremely abundant in all parts of the island, particularly in the more barren lowland areas where they are commonly seen abroad in the daytime and are so slow and incautious that they may be run down and caught with ease by hand. Feral cats still occur throughout the island as testified to by their numerous scats. Rabbits (Oryctolagus) were introduced at some point and are still present, though not in great numbers.

There can be little doubt that the flightless, ground-nesting native land birds and the nearly defenseless burrowing petrels were quickly exterminated by the great numbers of hogs, rats, cats, and dogs that overran the island soon after its discovery. Most of the extinctions very likely took place in the 16 th century.

Added to this grim picture were the effects of habitat destruction. The impact of great numbers of goats on the native vegetation can hardly have been less than extremely deleterious. Man devas- 
tated the forest cover for fuel and timbers, and any regrowth was prevented by goats. Several plant species became extinct, the most notable of which was the ebony tree Melhania melanoxylon, which was entirely destroyed to provide fuel for burning lime. The great forests of St. Helena were wiped out by the beginning of the 19th century (Melliss, 1875). Added to this were the numerous intentional introductions of exotic plants that began under the Portuguese and increased under later British colonization. Today the only remaining native vegetation, dominated now by the tree fern Dicksonia arborescens, is confined to a small area on the high central ridge of the island, and this area is fast being encroached upon by New Zealand flax (Phormium tenax), gorse (Ulex), and other introduced plants. Probably as a result of habitat destruction the endemic land snails of St. Helena fared poorly, and, as with the birds, a greater proportion of the species are known only from fossil and subfossil remains (Wollaston, 1878).

\section{History of Paleornithology on St. Helena}

As long ago as 1817, Barnes remarked on eggshells and bones found in deposits at Sugarloaf Hill. Seale (1834) called attention to the extensive bone beds at Prosperous Bay, ascribing specimens found there to the Wandering Albatross and Redbilled Tropicbird. The record of an albatross is certainly an error, having its origin in the abundant remains of frigatebirds (Fregata) that occur in the Prosperous Bay deposits. Seale also noted (1834:11) that "remains of a similar description are found near Sugarloaf Hill." Darwin (1844) likewise commented on bird bones and eggshells at Sugarloaf Hill.

In a short abstract, Blofeld (1852:196) relates finding "birdbones, perfect and fragmentary, in abundance" along with shells of extinct snails

about half a milc behind Longwood, at an clevation of about 1700 feet above the level of the sea, on a hill-side which is worn into numerous clefts or ravines by the heavy rains. The surface of the hill to a depth of 5 or 6 feet consists of dark mould and under this is a stratum of greyishbrown friable carth about 3 to 4 feet thick; in this latter bed the shells occur.

I was unable to locate any such deposit within the limits of Blofeld's vague directions; he may possi- bly have been referring to the deposits at Sugarloaf Hill but these are considerably more than half a mile behind Longwood. The same author also mentions bird bones found by a Capt. Wilkes at Turk's Cap Bay. Hutchinson (1950) has suggested that the provenance of these specimens was actually Prosperous Bay. Ashmole (1963b:395) considered this

doubtful, as the hill called 'Turk's Cap' is a highly distinctive one close to the bay named after it, and about a milc north of Prosperous Bay. However, we visited Turk's Cap Bay and could not find any bird remains, so the possibility cannot be excluded that the bones recorded as having been collected there in fact came from Prosperous Bay.

This possibility is quite the most likely in my opinion, as the two localities are adjacent and the Turk's Cap is quite visible from Prosperous Bay. I, too, found no bird remains or any suitable deposits for them anywhere in Turk's Cap Valley, the bottom of which is nearly solid rock, in marked contrast to the deep sediments of Prosperous Bay Valley.

Blofeld's specimens and those of Wilkes were examined by Richard Owen (Blofeld, 1852:196), who pronounced them to be of "marine birds," some of Wilkes' belonging "to the subgenus Puffinus." Murphy (1936), Bourne (1956), and Ashmole (1963b) all erroneously cite Lambrecht (1933:732) as having listed this record as Puffnus lherminieri without justifying the specific assignment. In fact, Lambrecht had merely listed this occurrence, with several such others, under the heading "spezifisch unbestimmte Puffinus-arten," which happened to follow a Bermuda fossil record of $P$. lherminieri. The same record appears elsewhere in Lambrecht's book (1933:270) as "Puffinus sp." Obviously Lambrecht made no specific identification of the St. Helena fossils, although as it turns out, $P$. lherminieri was indeed present in the fossil deposits of St. Helena.

Hutchinson (1950) detailed the history of the guano deposits on St. Helena, and Bourne (1956) discussed a cranium of a gadfly petrel (Pterodroma) in the British Museum that was collected somewhere on the island (see species accounts).

The first real breakthrough in our knowledge of the past birdlife of St. Helena came with the visit of members of the Ascension Island Centenary Expedition of the British Ornitholgists' Union 
(BOU) in 1958 and 1959. Collections of bird fossils were made at three locations on the island by $\mathrm{B}$. Stonehouse, D. F. Dorward, and N. P. Ashmole, and these, plus a small collection made by $\mathrm{Mr}$. Norman Kerr, formed the basis of a valuable report by Ashmole (1963b) indicating a number of avian species unknown at St. Helena today. The only new species named from these collections was a large rail described by Wetmore (1963). The rails of St. Helena, including a description of an additional fossil species, have been discussed elsewhere (Olson, 1973).

Ashmole's report, while of the utmost importance for calling attention to the character and diversity of the former avifauna of St. Helena, was nevertheless of a preliminary nature, many of the species being only tentatively identified and the collections themselves being fairly small and inadequate for quantitative studies. These collections, now in the British Museum, were very kindly lent to me for reexamination and are treated in the discussions below.

Additional collections of fossils were made from 1959 to 1970 by Arthur Loveridge and John William Bailey (for Loveridge), both of whom reside on the island. This material is housed at the $\mathrm{Mu}$ seum of Comparative Zoology and was generously lent to me for inclusion in this study. A small portion of these collections was examined and discussed by Ashmole (1963b).

The bulk of the material used in this study was collected by me during my stay on St. Helena from 5 June to 17 July 1971 and is now deposited in the National Museum of Natural History, Smithsonian Institution. I was able to find all the localities mentioned by Ashmole, plus a few other less productive fossiliferous sites. A total of 17 days was spent on actual collecting of fossils, and numerous others in prospecting and exploring for new sites. In most instances, bones were lying exposed on weathered deposits of sediment and needed only to be picked up. My procedure in all cases was to recover every bone or fragment of bone that appeared to be identifiable. This resulted in the collection of well over 3000 individual specimens, which with the BMNH and MCZ collections yielded a total of more than 4600 specimens. Several crevices and holes in cliffs were searched unsuccessfully for fossils, but no really suitable caves were encountered.

\section{The Fossil Deposits}

\section{Prosperous Bay}

The most productive site for bird remains was at the bottom of the deep gorge known as Prosperous Bay Valley, on the northeast side of the island. One of the island's major streams, arising in the central ridge and running through Fisher's Valley, flows in turn into the canyon of Prosperous Bay Valley, there to descend over $300 \mathrm{~m}$ in a series of three waterfalls. The canyon is about a mile long and is rimmed with sheer cliffs several hundred feet high. Access to the bottom of the valley is gained by means of a narrow footpath snaking. down the eastern face. The remote and silent canyon, with its dark, towering walls flecked with immaculate white nesting Fairy Terns and with its rushing falls at one end and a narrow wedge of sea visible at the other, is one of the most memorable scenes to be found on St. Helena.

Along the last quarter of the canyon bottom are extensive deposits of brownish sediment containing abundant bones and even eggshells of birds. These deposits have been cut through by the stream and further eroded by runoff (Figure 3). In places they may be almost 4 to $5 \mathrm{~m}$ thick. The lower layers appear more consolidated and usually contain pebbles and cinders but fewer bones than the upper layer. Nevertheless, at least one nearly complete articulated skeleton (the type of Porzana astrictocarpus Olson, 1973) was found in the lower strata about $1.5 \mathrm{~m}$ deep. The upper layer is composed of very fine, loose, dustlike soil containing unworn bones and associated skeletons of birds that were exposed or unearthed in great quantity. Occasionally, roots, pieces of wood, and other vegetable matter were also encountered.

Considering the manner of preservation of the bird material at this locality, it is, as Ashmole (1963b) indicated, hardly possible that the remains were washed down from the plains above the canyon. Ashmole presumed the soil itself to have been borne by water from higher areas, but suggested that the bones came from carcasses of birds nesting in the valley that were buried in sediment during flooding of the stream. Almost certainly the fine loose soil here was used as a nesting site by petrels and shearwaters, as its texture would be ideal for digging nest burrows. Indeed, 


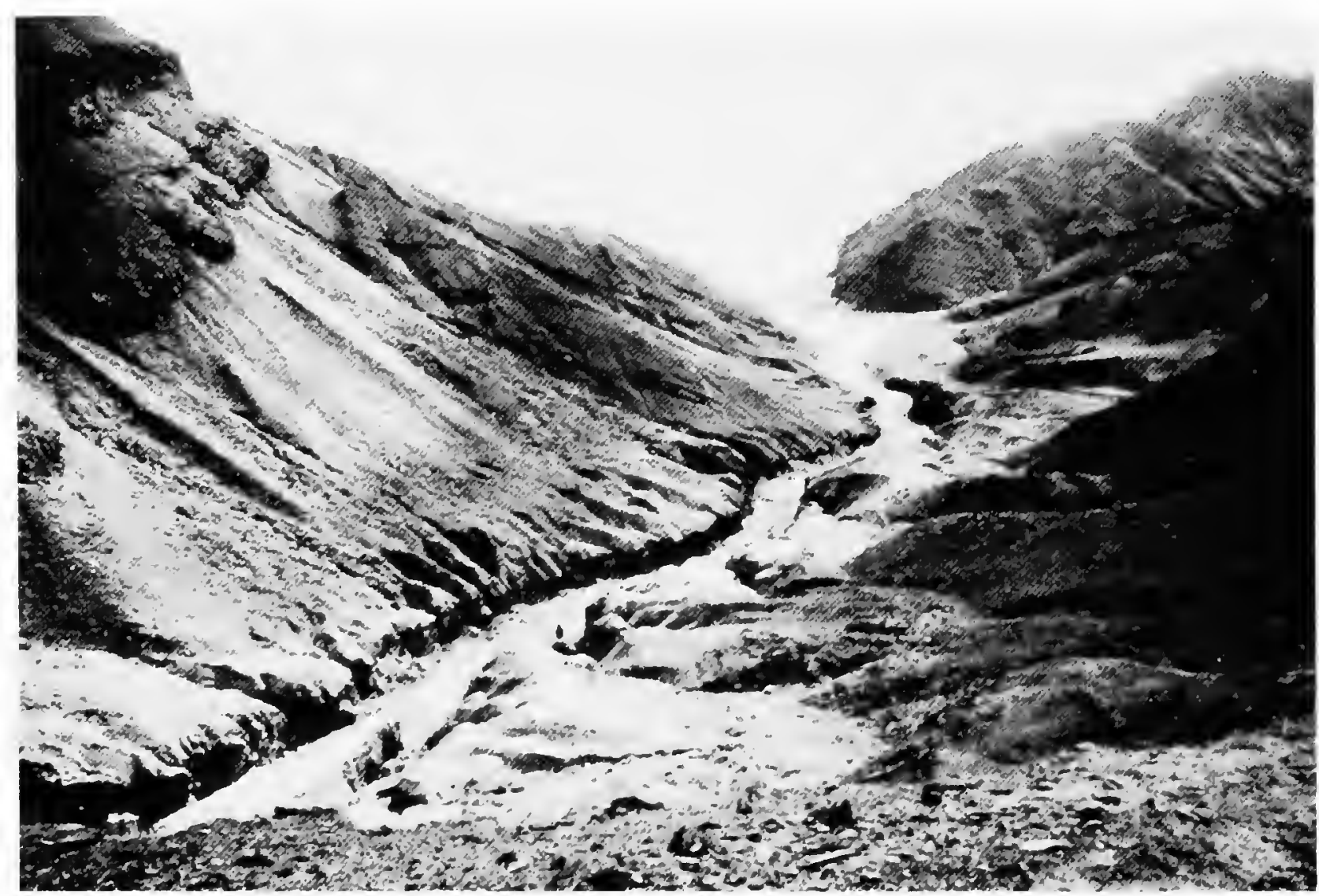

Figure 3.-The mouth of Prosperous Bay Valley, facing north. Bones of very recent age occur in the dissected sediments immediately on either side of the streambed.

on several occasions upon digging into an embankment I exposed open tunnels and hollows floored with loose, white material probably rich in guano. Also, in walking over these deposits I would from time to time plunge one or both legs into uncompacted hollows anywhere from ankle to almost waist deep, and I sometimes wondered if I might not stop sinking at all. It is not unreasonable to assume that when they were fully occupied these beds would have been absolutely riddled with burrows. That the birds were actually nesting here is attested to by the presence of eggshells and by the number of remains of small juvenile procellariids and frigatebirds. Natural deaths and those caused by the collapse of burrows could account for the accumulation of numbers of skeletons of at least the burrowing petrels. The presence of the surface-nesting frigatebirds and land birds may have been due to rapid subsidence or collapse of the loose soil, especially during rains, which would bury carcasses and perhaps even living birds.

The fine texture of the upper sediments at Prosperous Bay leads me to suggest that they might be at least in part acolian, the Prosperous Bay gorge acting as a trap for dust being blown off the extensive barren plateau known as Prosperous Bay Plain, that lies mainly to the windward. Burial by wind-blown dust could also explain the excellent preservation of the Prosperous Bay bones. The deposits were likely of considerably greater extent and depth at one time, and may be assumed to have been increasingly eroded as the island's vegetation was destroyed after the arrival of man.

The bones obtained at this site are unmineralized, and except for those exposed to the deleterious effects of sun, wind, and water, are in nearly perfect condition. The delicate, almost paper-thin bones of frigatebirds are well preserved in these deposits. The color of the Prosperous Bay bones is usually tan to dark brown, and some are etched with fine darker vermiculations probably caused by rootlets growing around them.

\section{Dry GuT}

Nearly two miles to the southwest of Prosperous Bay is another important fossil locality discovered in 1958 by Stonehouse and the BOU expedition, and subsequently exploited by Ashmole, Loveridge, and Olson. This is in the shallow valley known 


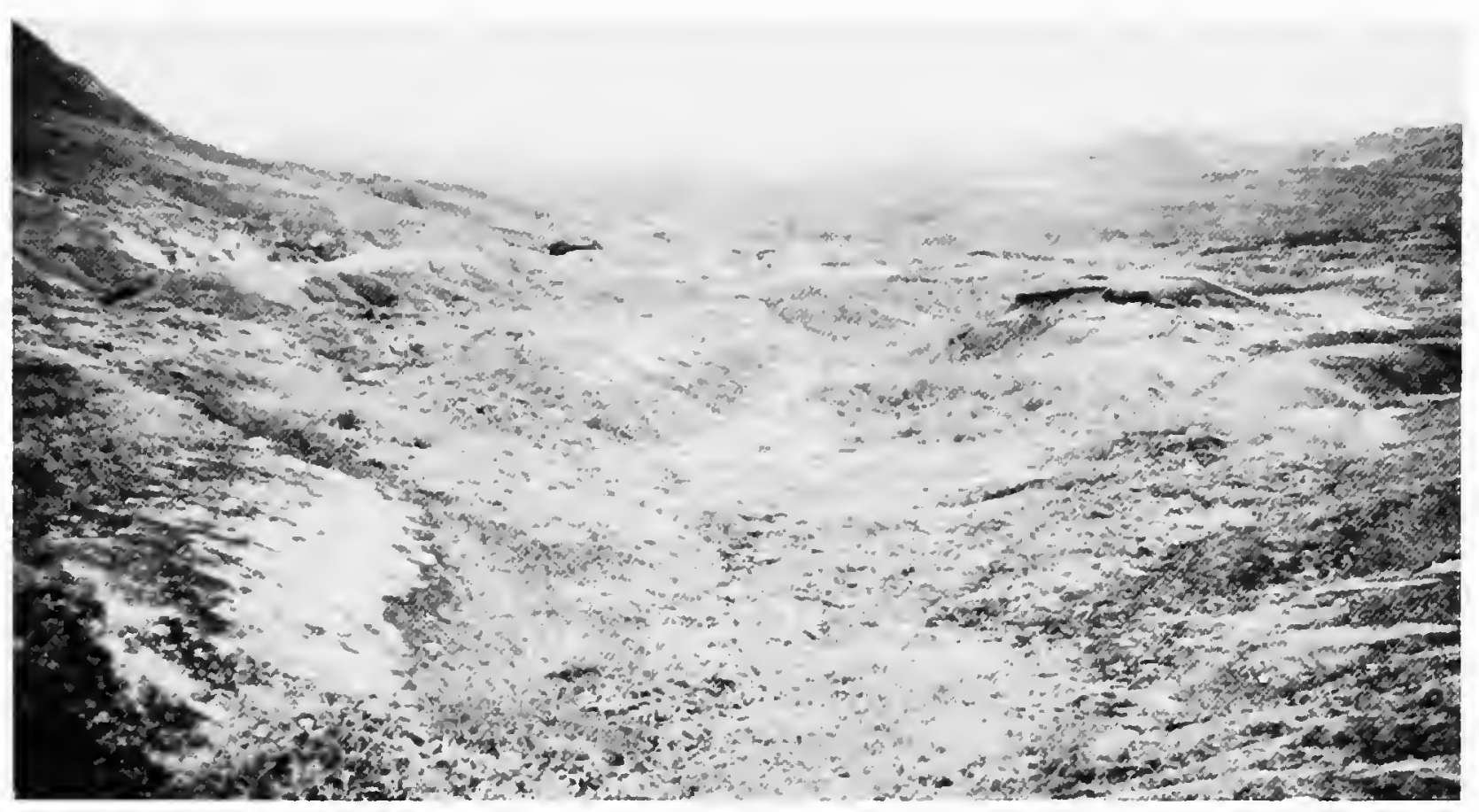

Figure 4.-The Dry Gut collecting site, facing west toward the center of the island. Bird fossils were found in fragmentary condition along the banks of the dry streambed in the midde foreground.

as Dry Gut just to the north of the rock mass called Bencoolen. This is not to be confused with another valley, also named Dry Gut, on the western side of the island south of Horse Pasture. (On all the midSouth Atlantic islands the word "gut" signifies a stream or stream bed-thus "Dry Gut" refers to a stream bed that is normally without water, rather than to a desiccated alimentary canal.)

Dry Gut is of considerable length but the productive fossil beds consist only of a number of low eroded mounds in the open and fairly level area at what would be about the 900 foot contour on a map of the island. At this point the gut divides up into several confluent gullies in the brown earth of whose banks the fossils were found (Figure 4).

The fossils here, unlike those at Prosperous Bay, are almost all fragmentary. No articulated bones were found, although occasionally two or more bones or fragments that appeared to come from a single individual would be found close to one another-e.g., the right and left humerus of a hoopoe found within a space of $1.5 \mathrm{~m}$. As Ashmole (1963b) has suggested, it seems possible that most of the fossils here have washed down from the sur- rounding low hillsides, although why they should be concentrated in such a relatively restricted area rather than being distributed along the length of the gut is not clear. The specimens are whitish in color and mineralized.

\section{Sugarloaf Hill}

In the vicinity of the distinctive promontory known as Sugarloaf Hill, which forms the northernmost point of the island, were found three separate deposits of fossils that I shall designate simply by number.

SiTE 1.-Between Sugarloaf Hill and the deep ravine of Banks Valley runs a smaller, parallel, dry valley terminating at the cliffs just north of Banks Valley Bay. This valley has two branches: one that runs northwest up along the southeast side of Sugarloaf and leading up to Site 2, and the other running southeast. At the head of the latter branch, a little over a quarter mile from Sugarloaf and at about $200 \mathrm{~m}$ ASL, is a series of low mounds of calcareous sand containing numerous fossils of birds and snails (Figure 5). These deposits have 
been noted and discussed by Barnes (1817), Darwin (1844), Melliss (1875), Daly (1927), Baker (1970), and Ashmole (1963b). The consensus is that this sand, the product of wave action upon shells of marine invertebrates, was blown to its present position here (and in several other localities on the island, some even higher) by strong winds. "The deposits are earlier than the five-meter raised beach which surrounds most of the island and probably represents a final eustatic lowering of sea level. The sands were formed at sea-level, either before the onset of the Plio-Pleistocene glaciations or during a warm interglacial period" (Baker, 1970:33). Muir and Baker (1968) suggest that the greatly increased winds necessary to transport this material to such elevations may have been the result of the northerly shift of the Antarctic ice cap during one of the Pleistocene glacial periods.

I noted that the fossils here did not occur in the pure deposits of hard-packed sand, but rather where the sand was mixed with soil. The pure calcareous sands, although not much consolidated, are often referred to in old accounts as "limestone" and were extensively quarried for use in making mortar. Barnes (1817:64) says:

in this quarry, at the depth of fourteen feet, small egg-shells in a perfect state have been repeatedly obtained; they are cmbedded in the limestone, which renders it difficult to extract them without injury. The superstratum of this part of the hill, and which rests upon the limestone, is a dark, friable earth, two or three feet in depth, in which are deposited numbers of small bones and fragments of eggshells, some of which appear to have been as large as a common hen's egg. There are no bones in the stratum of limestone.

Of the same deposits Darwin (1844:88) states:

the upper beds of the limestone, at the above-mentioned quarry on the Sugar-Loaf Hill, are softer, finer grained and less pure than the lower beds. They abound with fragments of land-shells, and with some perfect ones; they contain also, the bones of birds, and the large eggs, apparently of waterfowl. It is probable that these upper beds remained long in an unconsolidated form, during which timc, these terrestrial productions were embedded.

Comparing the old descriptions with the present. appearance it would seem that the quarrying oper-

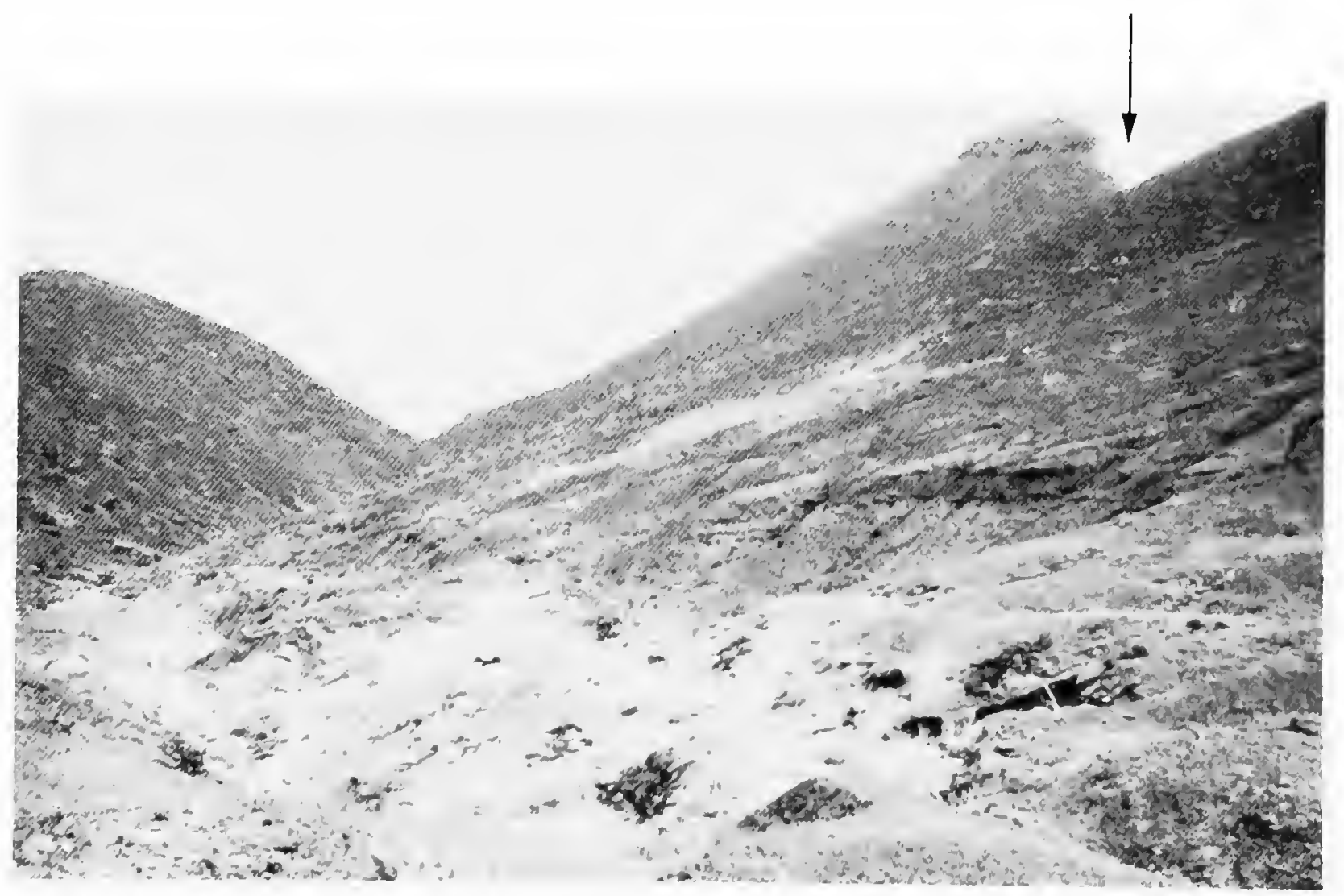

Figure 5.-Sugarloaf $\mathrm{Hill}$ is the distinctive promontory at the upper right. The light area in the foreground is the deposit of acolian calcarcous sand from which the oldest fossils on the island were recovered (Site 1). Sitc 2 (arrow), containing very recent bones, is out of view at the head of the valley formed by the hill in the right foreground and Sugarloaf Hill. Site 3 would lic somewhere to the right (northeast) of the photo. 
ations removed a great deal of material from these deposits and may have been responsible for the fragmentary nature of some of the fossils recovered here. I did, however, find an articulated skeleton of a Pterodroma in a cleft in a bank of the impure sand which, with the old accounts, is evidence that the fossils were deposited in situ rather than being washed in from some other area. The deposition of the fossils evidently took place after the main body of pure sand was formed. The fossils here are completely mineralized, having a porcelain-like sound when tapped, and are white or buffy in color, usually with fine black splotches and vermiculations.

Site 2.-At the head of the small valley that forms the southeastern delimitation of Sugarloaf Hill itself (Figure 5) is a long, steep deposit of dusty soil very much in appearance like that at Prosperous Bay. This deposit contains bones and eggshells in fair numbers and is characterized by a preponderance of storm-petrel remains. No specimens from this site were collected by the $\mathrm{BOU}$ expedition, but both Bailey and I made collections here. Unlike those from Site 1, the bones from Site 2 are unmineralized and are obviously of very recent age. Site 2 appears to be contemporaneous with the deposits at Prosperous Bay, and similarly contains remains of frigatebirds, unlike the older sites.

Srre 3.-In the collections submitted by Loveridge to the MCZ is a small series of fossils from yet another site near Sugarloaf that neither I nor the BOU party located. Loveridge (in litt., 14 August 1972) describes the locality as "topsoil on Sugarloaf Ridge at a point southeast of Sugarloaf Hill itself but on the northeast clifftop"; on the "second edition of the 1941 map of St. Helena [D. Survey, Ministry of Defense, U.K.] I should say it lies just midway between the triangle marking Sugar Loaf Hill and the indent marked 'Cavalho Hole.' It is concealed from the footpath by the crest of the summit shown on maps, said crest being the landward slope or bank of the hollow." This description fits neither Site 1 nor Site 2. Furthermore, the matrix on the specimens, a hardened dark brown soil, is unlike the sand of Site 1 or the dust of Site 2, but is quite similar to that at the Dry Gut locality. In addition, the state of preservation and the species composition (nearly all Pterodroma) are most similar to the material found at Dry Gut.

\section{Sandy Bay Valley}

On the southern side of the island, at nearly the exact opposite point on the island from Sugarloaf Hill, is the large valley leading to Sandy Bay. In this vicinity I discovered two minor fossiliferous sites. These I will designate Site A and Site B to avoid confusion with the numbered Sugarloaf localities.

Site A.-This is a low embankment of soil about $400 \mathrm{~m}$ north of the beach at Sandy Bay proper. At its base is the footpath leading to Sandy Bay. It lies immediately south of the opening of the last valley to enter Sandy Bay Valley from the east (Figure 6). About 25 to $30 \mathrm{~m}$ north of this embankment are the old stone ruins of some former military quarters. Bird bones were found lying exposed on or protruding from the embankment. One somewhat indurated clod of earth yielded much of an associated skeleton of a Pterodroma, and an articulated tibia and tarsus, complete with ossified tendons, of a small rail (Porzana astrictocarpus) were found nearby. This would seem to indicate deposition in situ, even though the area has been inhabited for a long time and has been much disturbed by human agency. Bones from this site are in excellent condition, being little worn and for the most part unmineralized, although some, particularly those of the associated Pterodroma skeleton, are encrusted with mineral. Most of these fossils appear to be quite recent and are probably nearest in age to those from Prosperous Bay and Sugarloaf Site 2. As with those deposits, Sandy Bay Site A contains bones (although few) of frigatebirds.

Site B.-This site lies not quite half a mile away, at the head of the valley that terminates at Site A. Here is found another of the island's deposits of aeolian calcareous sand, which at one time supplied the lime kiln, whose ruins may still be seen today, at the mouth of Sandy Bay Valley. Unlike Sugarloaf Site 1, however, there were no abundant fossils in these sands. In some of the gullies just above the sand deposits I found a dozen worn fragments of mineralized bone, mostly of the Pterodroma. 


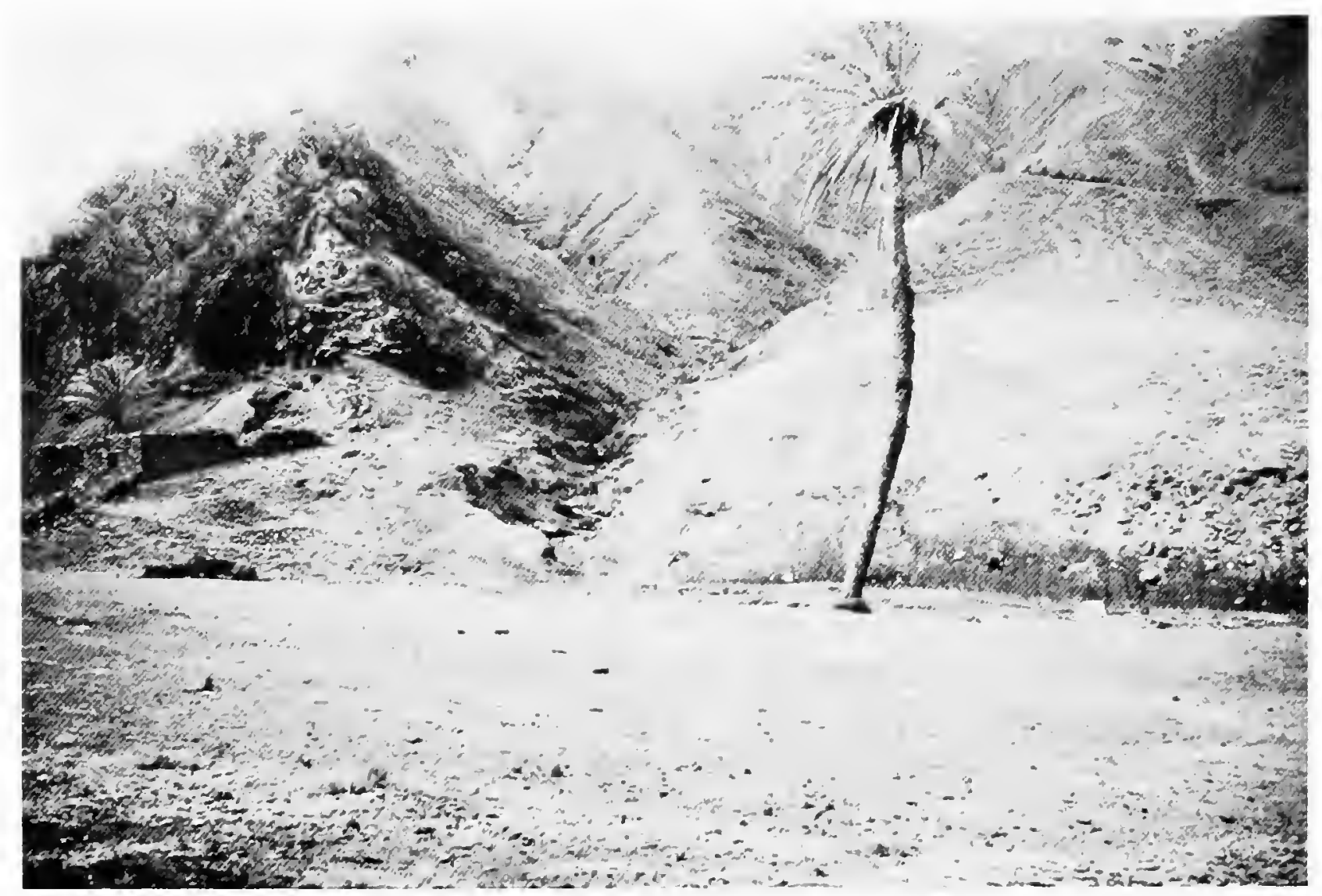

Figure 6.-The bones at Sandy Bay Valley (Site A) were found on the embankment immediately behind the base of the palm tree. Site B is up in the valley to the right of the top of the tree. The photo was taken facing east.

\section{Miscellaneous Finds}

In a wash on Turk's Cap Ridge at the head of the "gut" leading to the valley called "The Springs," I found a humerus of Puffinus lherminieri and one of Oceanodroma castro. On the trail along the north side of Banks Valley leading to Sugarloaf Site 1, I found another humerus of $O$. castro, and on the trail to Deep Valley an ulna of Gygis alba, the last quite recent. These show little except that one may expect to find scattered bird remains, sometimes of extirpated species, almost anywhere about the island.

\section{Age of the Deposits}

It has not yet been possible to determine the absolute age of any of the bone beds on St. Helena, but several lines of evidence indicate the probable ages of these deposits relative to one another. This information has considerable importance when viewed in light of the faunal differences between the deposits.

The deposits at Prosperous Bay are obviously very recent. The bones from there are unmineralized, very well preserved, and some fragments of eggshells of Sooty Tern still possess pigmentation. Ashmole (1963b:392) suggested that these deposits were "probably hundreds rather than thousands of years old." The nature of the deposits and the preservation of bone at Sugarloaf Site 2 are nearly identical to those of Prosperous Bay, and the contemporaneity of these two deposits is virtually certain. Most of the material from Sandy Bay Valley Site $\mathrm{A}$ is as recent.

The heavy mineralization of the bones at Sugarloaf Site 1 shows them to be much older than those at Prosperous Bay. Ashmole (1963b:394) indicated that these were "of considerable age, perhaps Pleistocene."

The bones from Dry Gut, while obviously older than those at Prosperous Bay, do not seem as heavily mineralized as those at Sugarloaf Site 1, and it seemed likely that these deposits were intermediate in age between those of Sugarloaf Site 1 and those of Dry Gut. Their species composition, furthermore, seemed explicable only if they were laid down after those at Site 1 and before those at 
Prosperous Bay (see "Discussion"). The preservation, matrix, and species composition of the Sugarloaf Site 3 deposits agreed best with those at Dry Gut.

Thus, on the basis of these rather subjective assessments, I tentatively grouped the deposits into three rough time periods: the oldest (Sugarloaf Site 1), a middle period (Dry Gut, Sugarloaf Site 3, and perhaps Sandy Bay Site B), and a recent period (Prosperous Bay, Sugarloaf Site 2, Sandy Bay Site A).

Dr. P. E. Hare of the Geophysical Laboratory, Carnegie Institution of Washington, subjected samples from four of these sites to chemical analysis which, happily for me, confirms the above groupings and relative ages. The following is his report:

Modern bone from various sources shows a nitrogen content ranging from $3 \%$ to $5 \%$ (Long, 1961). Generally, fossil bone shows decreasing amounts of nitrogen with increasing age. The rate of decrease is affected by the temperature and moisture of the surrounding environment, with higher temperature and greater rainfall favoring more rapid leaching of nitrogen from the bone. Within a restricted area such as St. Helena it should be possible to use the relative amounts of nitrogen as an indicator of relative age. Table 1 shows that the nitrogen content of the fossils does indeed correlate with the inferred temporal sequence of the four suites of samples. The most recent site at Prosperous Bay appears to be at least several hundred years old and perhaps as old as 1500 years as judged by comparison with some Egyptian material of known age. The "middle" and "older" periods are obviously much older. The $\mathrm{C} / \mathrm{N}$ ratio also increases with age. Some of the carbon is from carbonate in the bone and this does not leach out as does the nitrogen. The rate of nitrogen loss from bone decreases with time so
TABLE 1.-Percent nitrogen and carbon:nitrogen ratios in bone samples from St. Helena

\begin{tabular}{|c|c|c|}
\hline Locality & $\% N$ & $C / N$ \\
\hline Prosperous Bay (recent) & $2.3-2.5$ & 3.8 \\
\hline Sugarloaf Site 3 (middle) & 0.07 & 31.0 \\
\hline Dry Gut (middle) & 0.06 & 38.0 \\
\hline Sugarloaf Site 1 (oldest) & 0.04 & 57.0 \\
\hline
\end{tabular}

that for older samples the rate of change is very slow. Thus the difference between the oldest period and the middle period might well represent a longer span of time than that between the middle and recent periods.

The nitrogen of bone is contained almost entirely in the protein fraction. Collagen, the predominant protein constituent of bone, is leached out by ground water. At the same time the other protein constituents remaining in the bone are altered so that it may be possible to use the ratios of amino acids left in the bone as an age-dating tool (Hare, 1969).

In the series of samples from St. Helena, the bones from Prosperous Bay had appreciable amounts of collagen, whereas those from Sugarloaf Sites 1 and 3 and Dry Gut did not. In the samples from the older sites, amino acids were recovered but their significance has yet to be determined. Experiments on leaching of modern bone show a similar residual amino acid composition after the collagen has been leached out. Contamination seems ruled out since the matrix surrounding the fossil samples has quite a different amino acid pattern. It is not yet possible to assign absolute ages with any certainty. Specimens from both the middle and oldest periods of St. Helena are more altered from the original bone than a sample of Pleistocene bone from Maryland of approximately 60,000 years age. This may indeed mean that the St. Helena samples are older but caution is necessary until more data are accumulated on the effects of specimen size and temperature. At any rate, it is safe to say that they date from well back in the Pleistocene.

\section{PROCELLARIIFORMES}

The greatest loss of species and individuals on St. Helena came with the extinction of five of the six resident shearwaters and petrels. Thousands of bones of these birds were collected and thousands more remain. In its heyday, St. Helena must have been one of the major breeding-grounds for petrels in the Atlantic, its soil no doubt riddled with nesting burrows and the night air filled with the clamorous voices of countless birds. Now only a small population of a single species of stormpetrel remains of this once great multitude. In this instance, however, man is not solely responsible for the demise of these petrels, as several of the species had apparently been decreasing since some time in the Pleistocene and at least one species had died out by the time man and his destructive agents arrived.

Three of the petrels of St. Helena represent undescribed species and of even greater interest is the fact that two of these are members of speciesgroups now occurring in the Indian and Pacific oceans but unknown in the Atlantic. Thus we see that zoogeographic patterns in the Procellariiformes may be greatly affected by the extermination of a single island's fauna.

Several petrels, particularly in the genus Ptero- 
droma, have been thought to be extinct, only to be rediscovered at a later date. The disturbance on the main part of St. Helena has been so complete that it is virtually impossible that any living petrels will be found there. Still, some of the small offshore islets around St. Helena are nearly inaccessible and have been visited but seldom by ornithologists. A tiny population of one of the vanished petrels could conceivably still exist, but in the absence of suitable soil for burrowing on these islets, this seems highly unlikely.

\section{PROCELLARIIDAE}

\section{Genus Pterodroma}

The former presence of a medium-sized species of Pterodroma on St. Helena was first pointed out by Bourne (1956:127), who reported on a cranium in the British Museum "collected on St. Helena together with the shells of molluscs by a Lieut. Turton." After studying this specimen, Bourne tentatively concluded that it did not belong to $P$. arminjoniana, the only breeding species of Pterodroma in the tropical South Atlantic, but possibly was of the large race $P$. mollis feae, of Madeira and the Cape Verde Islands.

The BOU expedition (Ashmole, 1963b) collected specimens of limb bones and a partial rostrum of a medium-sized Pterodroma at Dry Gut and Sugarloaf Site 1. Ashmole agreed that this species did not belong to the $P$. arminjoniana group and pointed out that the bones were as close to $P$. cahow as they were to $P$. mollis. He felt that the taxonomic status of the species could not be determined with the material then at hand. Bourne (1965:99) later suggested that the St. Helena bird "might be one of the two little-known species of Reunion, Pterodroma aterrima and P. baraui."

From all seven fossil sites on St. Helena, I collected over a thousand specimens of this form, including all limb elements, two nearly perfect skulls, and an assortment of rostra and other cranial elements that permit a definite identification of the species. The limb bones of the St. Helena bird indicate a species larger than Pterodroma mollis mollis, $P$. inexpectata, $P$. hypoleuca, $P$. leucoptera, or $P$. cookii; smaller than $P$ arminjoniana, $P$. macroptera, $P$. baraui, $P$. hasitata, $P$. neglecta, or
$P$. lessonii; slightly smaller than $P$. phaeopygia; and about equal in size to $P$. cahow and $P$. alba.

However, as shown by the distinctive skulls, described below, the St. Helena bird does not belong to any of the above species or species-groups. Rather, it represents a new species of the IndoPacific $P$. rostrata group, heretofore unknown in the Atlantic.

\section{Pterodroma rupinarum, new species}

\section{Plate 1a}

HoLotype.-Nearly complete skull including rostrum, mandible, and quadrates, but missing most of the palate and the proximal half of the right side of the mandible. Vertebrate paleontological collections of the National Museum of Natural History (USNM 176594). Collected in recent sediment deposits at Prosperous Bay, St. Helena Island, South Atlantic Ocean, in June 1971 by Storrs L. Olson. Total length of skull with bill $72.1 \mathrm{~mm}$, width of cranium at postorbital processes 29.4, length of rostrum from anterior of nostril 20.7, length of mandible 58.8, depth of quadrate 11.2. The specimen is light yellowish tan in color and appears unmineralized.

PARATYPEs.-The paratypical series includes nearly all the elements of the skeleton from many individuals, as well as several associated skeletons in varying degrees of completeness (USNM $176203-176593$ and $176595-176718$; BMNH S/ 1963.25.7, S/1963.25.10, S/1963.25.11).

[After the present manuscript had been submitted, Loveridge forwarded to me a nearly complete skull and mandible of this species (USNM 176274) that was "found at a depth of five feet near Johnson's Rock, Sandy Bay District," by Leslie Williams on 12 November 1971.]

RANGE.-So far as known, the island of $\mathrm{St}$. Helena.

Sratus.-Extinct; present in Pleistocene to Recent deposits and presumably exterminated after 1502 .

ETYMoLogy.-Latin, rupinarum (of the rocky chasms).

Diagnosis.-A medium-sized Pterodroma belonging to the $P$. rostrata group as indicated by its very heavy, down-angled bill. Smaller than $P$. rostrata, somewhat larger and longer-winged than $P$ ater- 

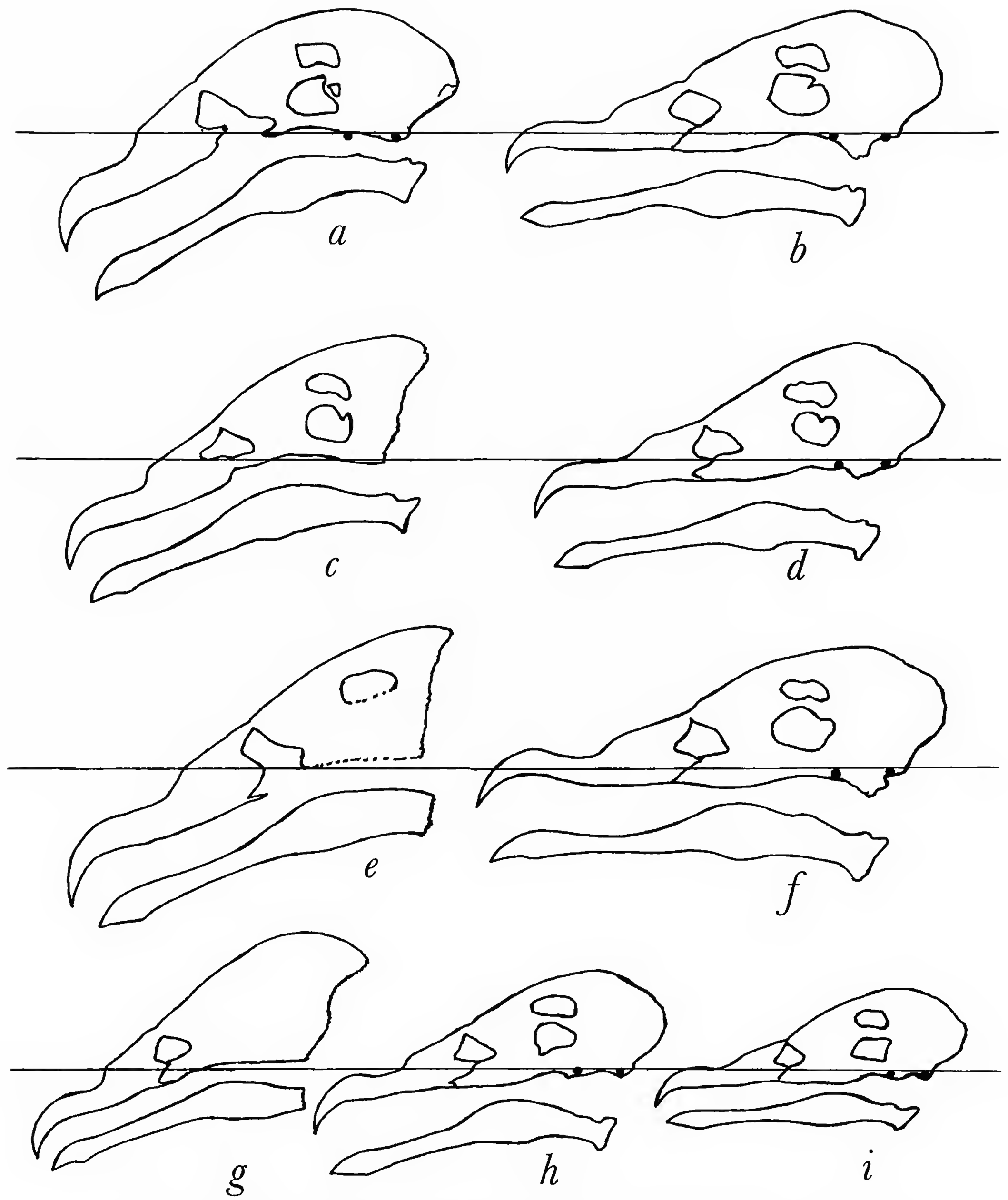

Figure 7.-Skull outlines of Pterodroma and Butweria: a, Pterodroma rupınarum, new species; $b, P$. arminjoniana; $c, P$. aterrima; $d, P$. alba; $e, P$. rostrata; $f, P$. baraui; $g, P$. becki; $h$, Bulweria fallax; $i, B$. bulwerii. The outlines have been made from $\mathrm{X}$-ray photographs; the black dots represent lead pellets used to show the basitemporal plate which provides the basis for the horizontal plane. Figures $c, e$, and $g$, were made from $\mathrm{X}$-rays of skins, and their orientation was therefore estimated. Note the heavy down-angled bills of the rostrata group $(a, c, e, g)$ and the much more decided angle of the mandible. 
rima or $P$. becki, but with proportionately shorter tarsi.

Discussion.-Analysis of P. rupinarum was hampered by a lack of skeletal material of the $P$. rostrata group. However, skins, X-ray photographs of skins, and a single fossil specimen of $P$ aterrima allowed comparisons to be made.

Working only with skins, Jouanin (1970) reached the perceptive conclusion that $P$. aterrima, known only from five specimens taken on Reunion Island in the Indian Ocean, was not related to the similarly colored $P$. macroptera, but rather to the Pacific species $P$. rostrata, which breeds in the Marquesas, Societies, and New Caledonia. The other living member of this group is the form becki, known only from two specimens taken at sea in the vicinity of the Solomon Islands. Pterodroma becki is a miniature version of $P$. rostrata, from which it may be only subspecifically distinct (Murphy, 1928; Murphy and Pennoyer, 1952).

The species of the $P$. rostrata group, including $P$. rupinarum, are set apart from other forms of Pterodroma by the greater depth of the bill both through the hooked portion and through the "latericorn" area, and by the greater width of the skull at the nasofrontal hinge. Even more striking is the very steep angle of the bill. In a series of skulls of Pterodroma, in order to determine the angle of the bill, the plane of the basitemporal plate was defined by gluing a small lead pellet just anterior to the occipital condyle, and another pellet at the posterior end of the parasphenoid rostrum between the basipterygoid processes. X-ray photographs were then taken of the skulls. The photographs were then aligned so that the basitemporal plates of the specimens were parallel. In this way it can be seen that the bill of $P$. rupinarum slopes sharply downward at an angle of about $30^{\circ}$ from the horizontal, whereas in the other species-groups of Pterodroma the bill is horizontal or nearly so (Figure 7). In accordance with the down-angling of the rostrum, the dentary portion of the mandible is also bent strongly downward in $P$. rupinarum. X-ray photographs were made from skins of $P$. rostrata, $P$. becki, and $P$. aterrima, and although the orientation of the skulls had to be estimated, it was evident that in these forms too, the rostrum and mandible are bent downward to the same degree as in $P$. rupinarum (Figure 7). This evidence serves to ally $P$. rupinarum with $P$. rostrata, $P$. becki, and $P$. aterrima and demonstrates that these four species constitute a very distinct group within the genus Pterodroma.

Measurements of the limb elements of $P$. rupinarum are presented in Table 2. The tarsi of 24 specimens of $F$. rostrata ranged in length from 45 to $50 \mathrm{~mm}$ (Murphy and Pennoyer, 1952:8), indicating that this species is much larger than $P$. rupinarum. The skull of $P$. becki is smaller than in $P$. rupinarum, while the tarsus of one specimen $(36 \mathrm{~mm})$ is within the size range of $P$. rupinarum and that of the other specimen is larger (37.2) than in $P$. rupinarum. Also, in $P$. rostrata and $P$. becki the distance between the nostrils and the base of the culminicorn is greater than in $P$. rupinarum and $P$. aterrima, in which the nostrils and base of the culminicorn are in near contact. The tarsi of the five specimens of $P$. aterrima range from 36 to $39 \mathrm{~mm}$, with an average of $38 \mathrm{~mm}$ (Jouanin, 1955, and this study). Thus the tarsi of all but one specimen are larger than in $P$. rupinarum. Measurements from an X-ray photograph of a skin of $P$. aterrima gave lengths of $41 \mathrm{~mm}$ for the carpometacarpus, $85.8 \mathrm{~mm}$ for the ulna, and $39 \mathrm{~mm}$ for the tarsus. Pterodroma rupinarum then must have had longer wings but shorter tarsi than $P$. aterrima.

I examined a rostrum from subfossil deposits on Rodrigues that was identified as $P$. aterrima by Bourne (1968). This differs most conspicuously from that of $P$. rupinarum in that the nostril openings are considerably smaller, and the premaxillary symphysis in ventral view is longer. The specific distinctness of $P$. rupinarum is confirmed on the basis of size, proportions, and qualitative characters of the bill.

Fossils of $P$ - rupinarum were found, often in great abundance, in fossil deposits representing all three time periods. Eggshells almost certainly

TABle 2.-Lengths $(\mathrm{mm})$ of the limb bones of Pterodroma rupinarum, new species

\begin{tabular}{|c|c|c|c|c|}
\hline Element & $n$ & range & mean & s.d. \\
\hline Humerus & 26 & $83.2-92.1$ & 89.0 & 2.23 \\
\hline Ulna ....... & 22 & $87.5-96.1$ & 91.7 & 1.99 \\
\hline Carpometacarpus & 34 & $42.0-46.4$ & 44.1 & 1.10 \\
\hline Femur & 33 & $29.1-33.2$ & 31.5 & 1.00 \\
\hline Tibiotarsus .. .... & 4 & $55.1-57.5$ & 56.1 & 0.97 \\
\hline Tarsometatarsus & 10 & $33.8-36.5$ & 35.7 & 0.78 \\
\hline
\end{tabular}


attributable to this species were found at Sugarloaf Sites 1 and 2 and at Prosperous Bay. Species of the $P$. rostrata group apparently breed only on high mountainous islands. Although St. Helena does not afford the great altitudes of the known breeding sites of the $P$. rostrata group, its relief and climate come closer to approximating those conditions than do any of the other South Atlantic islands.

\section{Genus Bulweria}

From the Sugarloaf Site 1 deposits, Ashmole (1963b) reported a few remains of a gadfly petrel much smaller than $P$. rupinarum. I collected about 250 additional specimens of this small species; unfortunately, no cranial elements were included. The only gadfly-type petrels in this size range are the species Pterodroma cookii, P. leucoptera, and $P$. longirostris, which are considered as forming a subgenus Cookilaria (Falla, 1942); the Pterodroma hypoleuca group, which includes $P$. hypoleuca, $P$. axillaris, and $P$. nigripennis; and the recently described species Bulweria fallax (Jouanin, 1955). The species of Cookilaria and the $P$. hypolenca group are confined to the Pacific. Bulweria fallax is found in the western Indian Ocean, particularly in the Arabian Sea. No species of this size occurs in the Atlantic today.

Ashmole (1963b) compared the small St. Helena petrel with the small species of Pterodroma, but no skeleton of Bulweria fallax was available to him at that time. Fortunately, I was able to examine one complete skeleton and one body skeleton of $B$. fallax. The small gadfly petrel from St. Helena definitely cannot be assigned to any known living species. After careful study of the material I believe that it is referable to the genus Bulweria rather than to Pterodroma.

\section{Bulweria bifax, new species}

\section{Plate 2}

HolotyPe.-Nearly complete right tarsometatarsus. Vertebrate paleontological collections of the National Museum of Natural History (USNM 176020). Collected in Pleistocene deposits of aeolian calcareous sand near Sugarloaf Hill (Site 1), St. Helena Island, South Atlantic Ocean, in June or July 1971, by Storrs L. Olson. Total length 24.9 $\mathrm{mm}$, width through trochleae 4.7 , depth through trochleae 3.5 , width of shaft at midpoint 2.3 , depth of shaft at midpoint 2.0. Color, white with dark vermiculations.

Paratypes.-Series of humeri, ulnae, radii, carpometacarpi, coracoids, lemora, tibiotarsi, and tarsometarsi (USNM 176021-176202; BMNH S/ 1963.25.8).

RANGE.-So far as known, the island of St. Helena.

Status.-Extinct; abundant in the oldest Pleistocene deposit (Sugarloal Site 1), but apparently much diminished in the later deposits (Dry Gut, Sugarloaf Site 3, Sandy Bay Valley Site A), and absent altogether from those at Prosperous Bay.

Etymology.-Latin, bifax (two-faced), from the species' resemblance to both Bulweria and Pterodroma.

Diagnosis.-A large Bulweria about the size of $B$. fallax with the relatively short, heavy tibiotarsus and tarsometatarsus characteristic of the genus but with the wing elements shorter and heavier than in B. fallax.

Discussion.-The relatively long and slender humeri of $B$. bifax separate it from Pterodroma, particularly the Cookilaria group in which the humerus is short and heavy. This leaves only Bulweria fallax as a possible relative, among species of comparable size.

The tarsometatarsus of $B$. bifax agrees with $B$. fallax in having the shaft heavier and more uniform in width than in Pterodroma, in which the shaft becomes narrower above the distal foramen (Plate 2B). The only complete tarsometatarsus of $B$. bifax, that of the type, is shorter $(29.4 \mathrm{~mm})$ than in eight specimens of $B$. fallax (range 30.333.1, mean 32.3). However, there is some variation in the size of the tarsal fragments of $B$. bifax, and a few of these are as large as in the one skeleton of $B$. fallax examined.

The tibiotarsus of $B$. bifax also agrees with $B$. fallax and differs from Pterodroma in its heavier shaft that does not become narrower in the distal quarter. The most complete tibiotarsus of $B$. bifax (BMNH S/1963.25.8-357) has present the distal end of the fibular crest. This, as noted by Ashmole (1963b:400), is lower than in any form of Pterodroma, and indicates a short stout tibia such as seen in B. fallax (Plate 2A). 
The femora of $B$. bifax are the same size (23.625.1 , mean $24.3 \mathrm{~mm}, \mathrm{n}=6$ ) as in two specimens of $B$. fallax $(24.9,24.5)$ but are less stout in the shaft, although they are slightly heavier than in $P$. hypoleuca.

The humerus of $B$. bifax is intermediate in proportions between the long, slender humerus of $B$. fallax and the heavier humeri of Pterodroma (Plate 2c). The only two intact specimens are shorter $(74.1,72.3 \mathrm{~mm}$ ) than in the one specimen of $B$. fallax (76.9), while within the size range of $P$. hypoleuca $(69.9-75.7 \mathrm{~mm}$, mean $72.6, \mathrm{n}=19)$. The humerus of $B$. bifax differs from that of $P$. hypoleuca in that the shaft is straighter, the distal end is not as wide and heavy, the ectepicondyle is reduced and not rotated internally so as to lie almost in the anconal plane, the head is lower and less bulbous, and in internal view the entepicondylar ridge does not extend as far anconally or distally. In these respects it agrees more closely with B. fallax. The brachial depression in B. bifax is deeper than in the single specimen of $B$. fallax and is more like that in $P$. hypoleuca. The extent and depth of this depression are variable in many species of Procellariidae.

Although variable in proportions, all of the ulnae of $B$. bifax are much heavier than the delicate ulna of $B$. fallax and are more similar to that of $P$. hypoleuca (Plate 2D). The only two intact specimens are much shorter $(69.5,71.8 \mathrm{~mm})$ than in $B$. fallax (80).

All of the intact carpometacarpi of $B$. bifax are smaller (34.9-36.8 mm, mean $35.8, \mathrm{n}=11$ ) than in B. fallax (37.8).

Although the species of Bulweria appear to form a natural group, there are very few characters by which they may be separated from Pterodroma (Olson, 1975). One of these characters is the proportions of the limb bones, Bulweria having longer and more slender wing elements, and shorter, heavier leg elements than Pterodroma. Bulweria bifax essentially has the leg elements of a Bulweria, the ulna of a Pterodroma, and a humerus intermediate between the two. Thus it may possibly have been nearer the ancestral stock that gave rise to both Bulweria and Pterodroma. It also provides a geographical intermediate between the populations of $B$. bulwerii in the eastern North Atlantic and $B$. fallax in the western Indian Ocean.

\section{Genus Puffinus}

Three forms of Puffinus were encountered in the St. Helena deposits. Two of these are referable to modern species. The remaining form, however, is distinct from any existing species and is a representative of a species-group that no longer occurs in the Atlantic. Seven fragments of leg elements of this species from Sugarloaf Site 1 were assigned by Ashmole (1963b:395) to "Puffinus sp., similar to $P$. pacificus." A distal end of a humerus, cataloged with these specimens but not mentioned by Ashmole, also belongs to this species. I collected 60 additional specimens of this form that confirm Ashmole's original impressions of it. These too, came only from the Sugarloaf Site 1 deposits.

The humeri in this bird are not markedly flattened and twisted distally as in the more specialized species of Puffinus. This eliminates from consideration all modern species except Calonectris (=Puffinus auct.) diomedea and C. leucomelas, and Puffinus carneipes, $P$. creatopus, $P$. gravis, $P$. pacificus, and $P$. bulleri. Of these species, all but $P$. pacificus and $P$. bulleri are far larger than the St. Helena bird. Puffinus pacificus and $P$. bulleri form a distinct species-group within Puffinus, often recognized as a subgenus, Thyellodroma. Puffinus pacificus breeds through much of the Pacific and Indian oceans, while $P$. bulleri nests only in New Zealand. In size and other characters, the St. Helena bird belongs to the pacificus-bulleri species group. There are, however, consistent differences between the St. Helena bird and the modern members of that group. These differences, some of which had previously been noted by Ashmole, are such that it is possible to accord full specific rank to the St. Helena bird.

\section{Puffinus pacificoides, new species \\ Plate lB, D-H}

Holotype.-Nearly complete left femur, with anterior portions of both condyles abraded. Vertebrate paleontological collections of the National Museum of Natural History (USNM 175963). Collected in Pleistocene deposits of aeolian calcareous sand near Sugarloaf Hill (Site 1), St. Helena Island, South Atlantic Ocean, in June or July 1971, by Storrs L. Olson. Total length $32.2 \mathrm{~mm}$, greatest 
proximal width 8.5 , width of shaft at midpoint 3.5 , greatest distal width 7.8. Color, white with dark vermiculations.

ParatyPes.-Femora and fragments of tibiotarsi, tarsometatarsi, humeri, ulnae, carpometacarpi, coracoids, rostra, mandible, and phalanges (USNM 175964-176019; BMNH S/1963.25.6).

RANGE.-So far as known, the island of St. Helena.

STATUs.-Extinct; known only from the oldest deposit on the island and presumed to have died out naturally during the Pleistocene.

Etymology.-Pacificus plus Greek oides (like or resembling), from the relationship of this form to the species Puffinus pacificus.

Dragnosis.-A medium-sized Puffinus of the pacificus-bulleri group. Larger and more robust than $P$. pacificus. Differs from $P$. pacificus and $P$. bulleri particularly in the greater development of the trochanteric ridge and flatter head of the femur, and the greater excavation of the cotylae and more narrowed trochleae of the tarsometatarsus.

Discussion.-Although generally within the size range of $P$. pacificus and $P$. bulleri, $P$. pacificoides averages larger (Table 3 ) and is decidedly more robust than $P$. pacificus. The femur is heavier than in $P$. pacificus and is more like $P$. bulleri in proportions. It differs further in the much more pronounced trochanteric ridge (Plate $1 \mathrm{D}, \mathrm{E}$ ) which is longer and bulges out laterally more than in $P$. pacificus or $P$ bulleri. Also, the head of the femur is distinctly flatter and less bulbous than in either of those two species.

The distal end of the tibiotarsus of $P$. pacificoides is heavier than in $P$. pacificus. The shaft of the tibiotarsus is wider and the fibular crest longer than in either $P$. pacificus or $P$. bulleri.

The tarsometatarsi of $P$ pacificoides have heavier shafts and more expanded cotylae than $P$. pacificus or $P$. bulleri. The intercotylar knob is much less massive and bulbous than that of $P$. bulleri and somewhat more delicate than in $P$. pacificus. A notable feature of $P$. pacificoides is the much deeper, more excavated, and more angular cotylae (Plate $1 \mathrm{~F}$ ). The internal crest of the hypotarsus extends farther posteriorly than in $P$. pacificus and is more like that of $P$. bulleri. Although the tarsometatarsus as a whole is heavier in $P$. pacificoides, the trochleae are narrower and more delicate than in either $P$. pacificus or $P$. bulleri (Plate $1 \mathrm{H}$ ).

The shaft of the humerus of $P$. pacificoides is heavier than in $P$. bulleri, but the condyles are more delicate than in that species and more closely approximate $P$. pacificus.

Although $P$. bulleri is a larger bird than $P$. pacificus, it has different proportions, the wing elements being the same length as, or actually shorter than, in $P$. pacificus. The ulnae of $P$. pacificoides are larger than in $P$. bulleri and would seem to indicate that its proportions were probably more like those of $P$. pacificus.

A portion of a premaxilla, here assigned to $P$. pacificoides, is much larger and heavier than in $P$. pacificus (Plate $1 \mathrm{~B}$ ) and is fairly similar to $P$. bulleri.

The Puffinus pacificus group apparently had an extensive history in the Atlantic, as bones of a species similar to $P$. pacificoides have been found in the Mio-Pliocene of North Carolina (Olson and Wetmore, in press). At this time, the island of St. Helena was probably just emerging. It is interesting that this species-group is now entirely absent in the Atlantic. If we may judge from the fossil record at St. Helena, it apparently died out naturally in the Atlantic at some time during the Pleistocene (see p. 38).

Table 3.-Hindlimb measurements $(\mathrm{mm})$ of three species of Puffinus (subgenus Thyellodroma)

\begin{tabular}{|c|c|c|c|c|c|c|c|c|c|c|}
\hline \multirow[t]{2}{*}{ Measurement } & \multicolumn{3}{|c|}{$P$. pacificus $(\mathrm{n}=17)$} & \multicolumn{4}{|c|}{$P$. pacificoides, new species } & \multicolumn{3}{|c|}{ P. bulleri $(n=3)$} \\
\hline & range & mean & s.d. & $n$ & range & mean & s.d. & range & mean & s.d. \\
\hline Length fe & $31.4-34.3$ & 33.2 & 0.76 & 5 & $32.8-36.3$ & 34.2 & 1.19 & $36.2-36.9$ & 36.5 & 0.38 \\
\hline Proximal width fe & $7.3-8.2$ & 7.9 & 0.29 & 6 & $8.0-8.7$ & 8.4 & 0.27 & $8.7-8.8$ & 8.8 & 0.12 \\
\hline Distal width tibia & $5.9-6.6$ & 6.2 & 0.21 & 8 & $6.0-6.8$ & 6.5 & 0.31 & $6.5-6.6$ & 6.5 & 0.08 \\
\hline Length tarsus $\ldots \ldots \ldots \ldots$ & $45.2-50.4$ & 48.2 & 1.21 & 1 & 49.2 & - & - & $51.0-52.3$ & 51.5 & 0.65 \\
\hline
\end{tabular}




\section{Puffinus griseus}

In the collection from Sugarloaf Site 1 is a worn distal end of a left humerus (USNM 176722) of a Puffinus much larger than $P$. pacificoides or $P$. lherminieri. It has the very flattened aspect of the more specialized members of the genus, thus eliminating the species of Calonectris and Puffinus gravis, $P$. creatopus, $P$. carneipes, $P$. pacificus, and $P$. bulleri as possibilities. The specimen is considerably larger than any of the remaining species of Puffinus, except $P$. griseus and $P$. tenuirostris. It is slightly larger than in $P$. tenuirostris and differs in having the entepicondylar area broader and more flattened, in which respect it agrees with $P$. griseus. Also from Sugarloaf Site $\mathrm{I}$ is a rostrum (USNM 176723) missing most of the hook but with the anterior margins of the nostrils preserved. This is smaller and more slender than in $P$. pacifcoides but is similar to $P$. griseus.

Today $P$. griseus breeds in great numbers in the subantarctic waters off South America, New Zealand, and Australia, and migrates to the northern areas of the Pacific and the Atlantic. If the two Sugarloaf specimens of $P$ griseus were from a single individual, it is probable that their occurrence on St. Helena was due to the accidental preservation of a migrant. If not, then the seemingly unlikely possibility that $P$. griseus once bred as far north as St. Helena, but had all but disappeared from there by the time the Sugarloaf Site 1 deposits were formed, must be entertained. Other Pleistocene rocords of $P$ griseus are from Sardinia (Brodkorb, 1963) and a cave in Cornwall (W. R. P. Bourne, pers. comm.).

\section{Puffinus lherminieri}

Ashmole (1963b) reported bones of a small Puffinus of the P. assimilis-lherminieri group from Prosperous Bay and Sugarloaf Site 1. I found remains of this species in all the collections except those from Sugarloaf Site 3. At Prosperous Bay it was the most abundant bird in terms of individuals.

Puffinus assimilis and $P$. lherminieri are allopatric and are perhaps but forms of a single species. Puffinus lherminieri is a warm-water form and in the Atlantic is known from Bermuda and the West Indies. A single bird of this species was captured and examined on Ascension Island (Stonehouse 1960:185-186; 1962:117), and the species is also known there from a fossil (Olson, in press). Puffinus assimilis is a cold-water form occuring in the Atlantic at Tristan da Cunha and Gough Islands (elegans), the Cape Verdes (boydi), and at Madeira, the Salvages, and the Canaries (baroli). Puffinus a. baroli has at times been considered a race of $P$. lherminieri. Puffinus assimilis and $P$. lherminieri differ mainly in color. I have been unable to find any structural differences in the skeletons of the two.

Measurements of the tarsi and humeri from St. Helena are compared in Table 4 to specimens of $P$ lherminieri from Bermuda and from a cave deposit on Mona Island (Puerto Rico). Interestingly, these show that there is a greater difference between the populations of Bermuda and Mona Island than between those populations and that of St. Helena, which is intermediate. I examined no skeletons of the Atlantic forms of $P$. assimilis, but tarsal measurements from skins (Table 4)

Table 4.-Some measurements $(\mathrm{mm})$ of Atlantic populations of the Puffinus lherminieri-assimilis group

\begin{tabular}{|c|c|c|c|c|c|c|c|c|}
\hline \multirow[t]{2}{*}{ Species } & \multicolumn{4}{|c|}{ Tarsomelalarsus } & \multicolumn{4}{|c|}{ Humerus } \\
\hline & $n$ & range & mean & s.d. & $n$ & range & mean & s.d. \\
\hline$P$. lherminieri Bermuda & 13 & $37.7-42.6$ & 40.2 & 1.35 & 15 & $63.3-68.8$ & 66.9 & 1.74 \\
\hline P. lherminieri Mona Island ............ & 2 & $37.9-39.6$ & 38.8 & 0.85 & 18 & $60.8-65.7$ & 62.6 & 1.34 \\
\hline$P$. lherminieri St. Helena & 40 & $36.5-41.7$ & 39.2 & 1.25 & 66 & $60.0-67.4$ & 63.8 & 1.80 \\
\hline P. l. lherminieri (Murphy ]927) & - & $39.0-43.0$ & 40.3 & - & - & - & - & - \\
\hline P. assimilis boydi (Murphy 1927) ........... & - & $37.0-39.0$ & 37.5 & - & - & - & - & - \\
\hline P. assimilis baroli (Murphy 1927). & - & $35.5-39.0$ & 37.1 & - & - & - & - & - \\
\hline P. assimilis baroli (2 in USNM) ........ & & $35.8-37.2$ & 36.5 & - & - & - & - & - \\
\hline
\end{tabular}


average smaller than the St. Helena specimens or those of $P$. lherminieri from Bermuda and Mona Island.

The St. Helena bird was apparently nearer in size to typical $P$. lherminieri than to the Atlantic forms of $P$ assimilis. Puffinus lherminieri is the form known to occur at Ascension Island, the nearest land to St. Helena. Also, the small shearwater on St. Helena became much more abundant in the later deposits, which seems to have been correlated with a warming trend (see p. 38). For these reasons it seems more probable that the St. Helena bird is referable to the warm-water tropical form $P$. lherminieri rather than to $P$-assimilis, if indeed these two forms are specifically distinct.

Ashmole (1963b:397) was impressed by the great difference in proportions of two of the three rostra from Prosperous Bay available to him. He considered this most likely explained by individual variation, but also suggested "the alternative possibilities that the two bills represent two different species, or two populations which existed at different times...." In the 12 additional specimens of rostra I collected, there are even greater extremes in proportions, but with every sort of intermediate condition represented. This same variability may be observed in skins (Murphy, 1927). The specimens of $P$. lherminieri from St. Helena certainly represent only a single variable form.

\section{OCEANITIDAE}

\section{Genus Oceanodroma}

\section{Oceanodroma castro}

This species still breeds on some of the off-lying rocks and islets around St. Helena but was not reported in the fossil record by Ashmole (1963b). I found remains of it in all deposits except those at Sandy Bay. On the islet known as Egg Island I found fairly numerous recent skeletal remains in crevices in the rocks and also collected two nonbreeding individuals on 11 July 1971.

De Naurois (in Bannerman and Bannerman, 1968:158) observed that in the Cape Verde Islands the proportion of breeding individuals of $O$. castro to those of Pelagodroma marina was about 1 to 100 . A similar but not as pronounced disproportion is evident at St. Helena (Table 7), where there was a paucity of remains of $O$. castro. The reason for the low numbers of $O$. castro in the living population is not clear, but the scarcity of fossils may be explained by the species' habit of nesting in holes and crevices in rocks, whereas $P$. marina is an obligate burrower. The ability to nest on rocky, predator-free islets is no doubt responsible for the fact that $O$. castro is the only species of procellariiform to survive at St. Helena.

\section{Genus Pelagodroma}

\section{Pelagodroma marina}

Bones of Pelagodroma marina from Prosperous Bay and Sugarloaf Site 1 were identified by Ashmole (1963b). I found the species in all deposits except Sandy Bay Site B, and it seems to have been fairly common in all time periods. In the Atlantic, Pelagodroma is known to breed only in the Salvages, Cape Verdes, and Tristan da Cunha. Elsewhere it breeds in the southwestern Pacific Ocean and around the southern and western coasts of Australia. Murphy and Irving (1951) suspected that $P$. marina had existed in the Indian Ocean at Amsterdam and St. Paul Islands but had been exterminated by introduced mammals. This has been confirmed by the discovery of bones referable to this species on Amsterdam (Jouanin and Paulian, 1960).

Geographic variation in Pelagodroma marina was reviewed by Murphy and Irving (1951), and Bourne (1953) made additional remarks, describing the Cape Verde population as a new subspecies. As shown by these authors, there is variation in size in this species that may be correlated with latitude. The only parameter by which the St. Helena population could be compared to skin specimens was the length of the tarsometatarsus. The measurements of 51 tarsometatarsi from St. Helena are compared with other Atlantic populations in Table 5. The St. Helena population is intermediate in size between the longer-legged northern populations in the Salvages and Cape Verdes, and the shorter-legged populations at Tristan da Cunha, and thus fits in perfectly with a north-south "cline" in tarsal length. Overlap with the other populations is far too great to consider recognizing the St. Helena fossils as a separate subspecies. 
Table 5.-Tarsal length $(\mathrm{mm})$ of Atlantic populations of Pelagodroma marina

\begin{tabular}{|c|c|c|c|c|c|c|}
\hline Race & Locality & Reference & $n$ & range & mean & s.d. \\
\hline hypoleuca & Salvages and Canaries & Bourne, 1953 & 12 & $42.0-47.0$ & 45.2 & - \\
\hline$"$ & $"$ & Murphy \& Irving, 1951 & 6 & $42.6-44.8$ & 43.5 & - \\
\hline eadesi & Cape Verde Islands & Bourne, 1953 & 17 & $42.0-48.0$ & 45.2 & - \\
\hline$"$ & $"$ & Murphy \& Irving, 1951 & 40 & $41.7-48.9$ & 44.7 & - \\
\hline$"$ & $"$ & this study & 78 & $40.0-49.4$ & 44.3 & 1.62 \\
\hline unassigned & St. Helena Island & this study & 51 & $39.9-45.7$ & 42.8 & 1.38 \\
\hline marina & Tristan da Cunha & Murphy \& Irving, 1951 & 5 & $39.0-42.1$ & 40.9 & - \\
\hline$"$ & $"$ & Bourne, 1953 & 7 & $40.0-42.0$ & 40.7 & - \\
\hline
\end{tabular}

\section{PELECANIFORMES}

\section{PHAETHONTIDAE}

\section{Genus Phaethon}

\section{Phaethon aethereus}

The Red-billed Tropicbird is one of the few seabirds that still survives on St. Helena, nesting on the precipitous cliffs around the island, particularly those it Great Stone Top. Ashmole (1963b) did not record it as a fossil nor did I collect a single fossil example. Only in the MCZ collections from Prosperous Bay is there any past representation of the species - a coracoid, distal end of a humerus, and a vertebra, all apparently from a single individual. The cliff-nesting habits of $P$. aethereus are no doubt responsible not only for its virtual absence in the fossil record of St. Helena, but also for its survival.

\section{FREGATIDAE}

\section{Genus Fregata}

No frigatebirds are found on St. Helena today, but even without the fossil record there is evidence of their former occurrence on the island. In 1698, Leguat (Oliver, 1891:298) recorded "Frégates" at St. Helena. Barnes (1817:103) mentions that "the frigate pelican, or man of war, pelicanus [sic] aquilus" on St. Helena "is a large, dark-coloured bird, in length from three to four feet, and ten to fourteen feet in width, from the extremities of the wings; it soars to a great height, from which it darts with wonderful rapidity to seize its preyusually the flying fish." The dimensions are ob- viously exaggerated. Lesson (Lesson and Garnot, 1828:486), visiting the island in 1825, listed "les men-of-war ou frégates." Melliss (1870:105) gives the following short account:

Tachypetes aquilus (Linn.) "Man-of-war-bird." Although there is a part of the south-west coast designated "Man-ofwar Roost,' owing its name to this species, and there is still living evidence of its having once frequented the landing-steps at Jamestown, this bird is seldom now to be met with, nor is it easy to assign a reason for its disappearance from the island.

No known skins of Fregata from St. Helena exist. Four of the five species of frigatebirds currently recognized occur in the South Atlantic ( $F$. magnificens at Fernando de Noronha and the Cape Verdes, $F$. aquila endemic to Ascension, and $F$. minor and $F$. ariel at Trindade). It thus becomes of interest to determine which species inhabited St. Helena, as any of the four would seem possible. Ashmole (1963b) recognized only one species of frigatebird among the subfossil remains he studied, but the much more extensive subsequent collections reveal that there were two species-a small one and a large one, similar to the situation at Trindade.

\section{Fregata ariel trinitatis}

The most abundant remains of Fregata, recovered in great numbers at Prosperous Bay and also represented in the Sugarloaf Site 2 and Sandy Bay Valley Site A deposits, are of a species too small to agree with any of the recognized species of Fregata except F. ariel, to which species Ashmole (1963b) assigned all of his frigatebird specimens. I made comparisons of the St. Helena re- 
mains with 11 skeletons of $F$. ariel from the Pacific and Indian oceans. Somewhat surprisingly, there proved to be considerable differences between them.

The wing elements of the St. Helena birds are significantly heavier than in Indo-Pacific ariel and there is practically no overlap in the shaft widths, or the width/length ratios of the humeri and ulnae of the two populations. The width/length ratio of the rostrum and the width of the median ridge of the culmen likewise differ. The osteological differences between the small St. Helena Fregata and Indo-Pacific ariel are greater than those observable in the skeletons of the two recognized species $F$. minor and $F$. magnificens. Were there not already an extant population of small Fregata in the South Atlantic, I would have no hesitation about referring the St. Helena birds to a new species.

On the South Atlantic island of Trindade and the neighboring islets of Martin Vas, some 1200 $\mathrm{km}$ east of Brazil, there occurs a population of small frigatebirds currently assigned to the species ariel and which Ribeiro (1919) described as a new subspecies, trinitatis, on the basis of a supposed size difference derived from measuring a single specimen. However, there are no significant size differences between any of the populations of $F$. ariel (Olson, unpubl. data). Nevertheless, four humeri removed from skins of $F$. a. trinitatis were as heavy as the specimens from St. Helena and had wider shafts than any of the Indo-Pacific specimens of $F$. ariel. Furthermore, there appear to be some rather important differences in plumage between the Trindade and Indo-Pacific populations of ariel, which, with the osteological differences, suggest the possibility that trinitatis may prove to be specifically distinct. Additional discussion of this problem is deferred pending an expedition to Trindade to obtain further information and specimens. Until then, I provisionally regard trinitatis as a distinct form of $F$. ariel to which the small Fregata of St. Helena may be confidently assigned.

\section{Fregata minor}

Far less abundant in the frigatebird material from Prosperous Bay are the remains of a much larger species of Fregata. An individual of this larger form was also collected at Sugarloaf Site 2. I have been unable to find a good consistent character by which all skeletons of $F$. minor can be separated from $F$. magnificens. However, certain individuals of $F$. minor have heavier bills (latericorn portion deeper) and stouter humeri than in any of the specimens of $F$. magnificens examined. The best preserved specimen of the large Fregata from St. Helena, which includes a nearly perfect skull and mandible, as well as much of the rest of the skeleton, agrees with these extreme individuals of $F$. minor. Fregata minor is the characteristic frigatebird of oceanic islands and occurs together with $F$. a. trinitatis on Trindade. In all known cases of sympatry in the genus Fregata, one of the two sympatric species is always $F$. minor, this species occurring sympatrically with $F$. a. ariel, $F$. magnificens, and $F$. andrewsi, as well as $F$. $a$. trinitatis. There is little reason to doubt that the large species of Fregata on St. Helena is referable to $F$. minor.

In sorting the more fragmentary remains of Fregata it is possible that I have included some specimens of $F$. minor with those of $F$. a. trinitatis, but even allowing this, $F$. minor is decidedly the less common of the two on St. Helena (Table 8). This is the opposite of what has been reported for Trindade, where $F$. minor predominates; however, the status of $F$. a. trinitatis may have been altered on Trindade by the disappearance of the Caesalpina forest during the 18th century (Murphy, 1936:173).

\section{SULIDAE}

\section{Genus Sula}

No species of Sula is definitely known to breed at St. Helena today. Neither Benson (1950) nor Haydock (1954) observed boobies during their visits to the island. I did not encounter them but the natives are familiar with the birds, which they call "gannet" or "duck" and which are said to be found on George and Shore Islands on the eastern (windward) side of the island. Mundy (Temple, 1914:332) mentions the presence of "Gunnet" in 1634. Leguat (Oliver, 1891:298) saw boobies ("Fous") around one of the offshore rocks, (probably Speery I.) in 1698. Melliss (1870: 
105) lists "Sula, sp. ? 'Booby" "with the comment that it "seldom occurs on the Island, but frequents the neighbourhood. It is often seen from shipboard near the Island, but I have not had an opportunity of examining a specimen." The following evidence documents the occurrence of the three South Atlantic species of boobies at St. Helena, all of which probably bred there at one time, if they do not still do so on occasion.

\section{Sula dactylatra}

Two of the unidentified booby bones from Prosperous Bay discussed by Ashmole (1963b) are of this species. Also from Prosperous Bay there are bones of four additional individuals in the USNM and MCZ collections. At Dry Gut I collected a distal fragment of a tibiotarsus and a fragment of a coracoid of $S$. dactylatra. These remains may be readily distinguished from $S$. sula and $S$. leucogaster by their considerably larger size. There seem to be no recent records or sightings of this species at St. Helena, and the paucity of fossil specimens probably indicates that it was never as abundant a breeding bird there as it was on Ascension.

\section{Sula sula}

Ashmole (1963b) reported a tarsus from Prosperous Bay (MCZ 3251) as being definitely referable to Sula sula. Several bones of a single individual in the BMNH collections from Prosperous Bay are also of this species, as is a coracoid I collected. Recent records of $S$. sula are discussed in the following account.

\section{Sula leucogaster}

There are no fossils of S. leucogaster from St. Helena, probably because this species is principally a cliff nester. Ashmole and D. F. Dorward sighted a single adult each of $S$. leucogaster and $S$. sula on Shore Island, 5 May 1959 (Stonehouse 1963: 481). Recent specimen evidence of these two species is provided by two previously unreported skins of white-phase adult male $S$. sula (YPM 44210, 44211) and an adult male and female of S. leucogaster (YPM 44269, 44267) taken at St. Helena on 10 October 1925 by W. Kenneth Cuyler of the Cleveland Museum's Blossom Expedition. Four specimens of Sterna fuscata with the same data are labeled "George Island" and the boobies were no doubt collected either there or on Shore Island.

\section{GRUIFORMES}

\section{RALLIDAE}

St. Helena once enjoyed the presence of two species of flightless rails. Only brief discussions of these species are presented here as they have been treated in some detail elsewhere (Olson, 1973).

\section{Genus Atlantisia}

\section{Atlantisia podarces}

Remains of a very large rail were collected by the B.O.U. expedition at Prosperous Bay and described by Wetmore (1963) as a new genus and species, Aphanocrex podarces. I collected more material of this rail at Prosperous Bay, Sandy Bay Site A, Dry Gut, and Sugarloaf Site 1, indicating that the species had long been established on the island. Subsequent comparisons revealed that Aphanocrex is actually referable to the genus
Atlantisia, which has other representatives on Ascension Island ( $A$. elpenor) and Inaccessible Island in the Tristan group (A. rogersi). Atlantisia is believed to be derived from a pro-Rallus stock that has been replaced on the mainland but which has left relict descendants on a number of islands.

Atlantisia podarces was quite large, almost the size of the New Zealand Weka (Gallirallus australis), but of more slender build. It was flightless but had slightly better developed wings than the other species of Atlantisia and had strong toes with extremely long claws. These I believe were adaptalions that enabled this heavy bird to climb and flutter up the steep valley walls so characteristic of St. Helena. Atlantisia podarces could have been a predator on the eggs and young of both the terrestrial and pelagic birds of St. Helena, and probably preyed upon the island's abundant snail fauna as well. 


\section{Genus Porzana}

\section{Porzana astrictocarpus}

Previous to my visit, there had been no indication of a second species of rail in the fossil record of St. Helena. However, I found bones of a species much smaller than Atlantisia podarces to be relatively common at Prosperous Bay, Sandy Bay Site A, and Dry Gut. This bird was also quite flightless and was a short-billed crake of the genus Porzana that $I$ have named $P$. astrictocarpus (Olson, 1973), owing to the peculiar shape of the carpometacarpus.

Porzana astrictocarpus appears to be a derivative of the widespread species Porzana pusilla, which occurs in Africa, Europe, Asia (including Japan), and the Australian region (including New Zealand). I consider Porzana ("Porzanula") palmeri of
Laysan Island in the Pacific to be another flightless derivative of $P$. pusilla. Thus it appears that a single mainland species has given rise to two flightless species on islands on opposite sides of the world.

\section{Genus Gallinula}

\section{Gallinula chloropus}

The Common Gallinule is an abundant resident of marshy places on St. Helena today. Specimens are inseparable from the African race G. c. meridionalis. I have given reasons (Olson, 1973) why I believe that this species is a recent immigrant to the island that has established itself since the coming of man. The complete absence of Gallinula from any of the fossil material lends support to this theory.

\section{CHARADRIIFORMES}

\section{CHARADRIIDAE}

\section{Genus Charadrius}

\section{Charadrius sanctaehelenae}

The plover Charadrius sanctaehelenae is the only endemic bird extant on St. Helena. It is well known to the islanders, who call it "Wirebird" because of its spindly legs, and it is considered as a sort of avian symbol of the island. It is one of the very small number of shorebirds endemic to oceanic islands.

Several authors have regarded $C$. sanctaehelenae as a race of the African plover $C$. pecuarius. According to Bock (1958:71), "the differences between the two forms are the larger size and the lack of tan color on the breast of sanctaehelenae. These two forms are similar in all other respects and there is no reason to consider them as distinct species." Pitman (1965), who observed both forms in the field, concurred. Bock's statements, however, are not accurate.

Peters (1934) and Chapin (1939) maintained C. pecuarius and $C$ : sanctaehelenae as separate species. Vaurie (1964) assessed the characters of both forms and reached the same conclusion, with which I am in full accord. The Wirebird, to begin with, is a considerably larger bird than $C$. pecuarius (Table 6). In weight it would probably be at least a third heavier. The primary formula of $C$. sanctaehelenae is different $(2,1=3,4,5$; or 2,1 , $3,4,5)$ than that of $C$. pecuarius $(1,2,3,4,5)$, the wing thus being rounder. As Vaurie indicated, the primaries themselves are much broader and rounded in $C$. sanctaehelenae, not narrow and acuminate as in $C$. pecuarius, and are a darker more velvety black with darker shafts than in $C$. pecuarius. It is not completely true, however, that $C$. sanctachelenae lacks tan coloration on the breast. Freshly taken adult specimens have a decided buffy wash below, and this buffinesss is even more pronounced in recently fledged juveniles. Still, the species is never as dark buff below as are most individuals of $C$. pecuarius.

Vaurie (1964) noted that the proportions of the two species differ, the tail and tarsus of $C$. sanctaehelenae being relatively longer. Differences in proportions are also shown in the skeletons (Table 6). Relative to sacrum length the coracoid and wing elements of the two species are identical, but the length and depth of the sternum of $C$. sanctaehelenae are smaller, while the leg elements are considerably longer than in $C$. pecuarius. Granting that $C$. sanctaehelenae was probably derived directly from $C$. pecuarius, it is still preferable to 
maintain it as a separate species on account of its marked differentiation from the parental stock. Although the two have practically no chance ever of coming in contact, there is room to doubt that they would interbreed if they did, especially considering their size differences.

The Wirebird is found in the open, largely barren plains in the lower parts of the island and to a lesser extent in pastures. There is, of course, little likelihood of its ever having been a forest bird. Benson (1950) reasoned from this that either the old accounts of the island being covered entirely with forest were inaccurate or that there was the unlikely possibility that $C$. sanctaehelenae evolved in the $300+$ years between man's first alteration of the flora and the 1842 date of the collection of the oldest known specimens of the species. This last hypothesis becomes even less likely when it is remembered that Mundy observed this species in 1638 and 1656 (see p. 5).
Fossils of $C$. sanctaehelenae occurred very uncommonly in three of the deposits investigated by Loveridge and me, thus removing any possibility of the species having evolved in 300 years. A humerus and a femur were found at Prosperous Bay, the distal two-thirds of a femur at Dry Gut, and an ulna at Sugarloaf Site 3. The humerus, although lacking part of the head, is slightly longer and noticeably more slender than in four recent specimens. The intact femur is slightly smaller $(22.7 \mathrm{~mm})$ than eight recent specimens (23.4$24.4 \mathrm{~mm}$ ). The ulna, at $32.7 \mathrm{~mm}$, equals the smallest of four recent specimens. The samples are inadequate to indicate whether the slight differences in size of the fossils actually represent a tendency toward the size and proportions of the C. pecuarius ancestor or whether they fall within the normal range of variation of modern C. sanctaehelenae. In any case, the fossils are all from individuals larger than $C$. pecuarius.

TABLE 6.-Comparison of size and proportions of Charadrius pecuarius $(\mathrm{n}=5)$ and $\mathrm{C}$. sanctaehelenae $(\mathrm{n}=4)$

\begin{tabular}{|c|c|c|c|c|c|}
\hline Measurement & Species & range & mean & s.d. & $\begin{array}{l}\text { mean } \div \\
\text { synsacrum }\end{array}$ \\
\hline \multirow{2}{*}{ Length sternum .... .. $\ldots \ldots \ldots}$. & pecuarius & $23.9-28.1$ & 25.8 & 1.63 & 1.53 \\
\hline & sanctaehelenae & $27.0-27.9$ & 27.5 & 0.32 & 1.45 \\
\hline \multirow{2}{*}{ Depth carina .................. } & pecuarius & $12.9-14.7$ & 13.7 & 0.58 & 0.81 \\
\hline & sanctaehelenae & $13.4-13.6$ & 13.5 & 0.08 & 0.71 \\
\hline \multirow{2}{*}{ Length coracoid $\ldots \ldots \ldots \ldots \ldots$} & pecuarius & $11.9-12.9$ & 12.5 & 0.38 & 0.74 \\
\hline & sanctaehelenae & $13.6-14.4$ & 14.0 & 0.29 & 0.74 \\
\hline \multirow{2}{*}{ 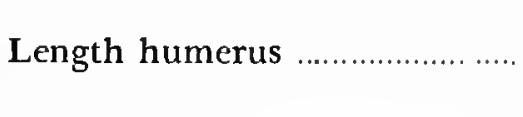 } & pecuarius & $25.9-28.9$ & 27.3 & 1.19 & 1.62 \\
\hline & sanctaehelenae & $30.4-31.2$ & 30.8 & 0.28 & 1.62 \\
\hline \multirow{2}{*}{ 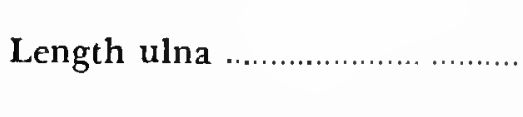 } & pecuarius & $27.6-31.6$ & 29.6 & 1.60 & 1.75 \\
\hline & sanctaehelenae & $32.7-34.0$ & 33.4 & 0.51 & 1.75 \\
\hline \multirow{2}{*}{ Length carpometacarpus } & pecuarius & $15.2-17.5$ & 16.2 & 0.83 & 0.96 \\
\hline & sanctaehelenae & $17.7-18.0$ & 17.8 & 0.13 & 0.94 \\
\hline \multirow{2}{*}{ Length synsacrum } & pecuarius & $16.2-17.8$ & 17.0 & 0.54 & 1.00 \\
\hline & sanctaehelenae & $18.1-19.5$ & 19.0 & 0.55 & 1.00 \\
\hline \multirow{2}{*}{ Length femur } & pecuarius & $18.4-20.5$ & 19.3 & 0.72 & 1.14 \\
\hline & sanclaehelenae & $23.8-24.4$ & 24.0 & 0.33 & 1.26 \\
\hline \multirow{2}{*}{ Length tibiotarsus } & pecuarius & $35.5-44.3$ & 39.4 & 3.32 & 2.33 \\
\hline & sanctaehelenae & $51.7-54.6$ & 52.7 & 1.15 & 2.77 \\
\hline \multirow{2}{*}{ Length tarsometatarsus } & pecuarius & $24.6-33.3$ & 28.1 & 3.83 & 1.66 \\
\hline & sanctaehelenae & $39.9-42.5$ & 40.6 & 1.08 & 2.14 \\
\hline
\end{tabular}




\section{LARIDAE}

\section{Genus Larus}

\section{Larus sp.}

At Dry Gut, I collected a proximal end of a right humerus of a large gull. The specimen was embedded in the indurated clay exposed in a small erosion gully, rather than being at the surface of the looser sediments where most of the other Dry Gut fossils were found. It is well mineralized and probably of some antiquity. It was recognized as significant at the time of collection but despite intensive searching in the vicinity, no other gull fossils were found.

The bone is from a large species of Larus, the size of L. fuscus, L. argentatus, or L. dominicanus. It differs from any example of Larus seen in that the septum dividing the "pneumatic" fossa curves externally to delimit a more circular external fossa than found in other specimens (Figure 8). However, the configuration of these fossae in the humerus of Larus is subject to a great deal of individual variation-to the extent that practically no two individuals are exactly alike. The characters shown by the St. Helena fossil are thus probably not attributable to specific differences and it is not otherwise diagnostic enough to be assigned to a particular species.
The absence of further remains of Larus in the St. Helena fossil collections suggests strongly that the specimen in question came from a vagrant. Although gulls may often wander to remote, tropical oceanic islands, they seldom establish breeding populations. Possible explanations for this are summarized and discussed by Sibley and McFarlane (1968).

I know of no modern records of gulls from St. Helena. Larus fuscus winters commonly along the West African coast to the Gulf of Guinea, rarely wandering farther south (Watson, 1966). Larus dominicanus breeds in South Africa and is of regular occurrence at Tristan da Cunha, although apparently not nesting there (Hagen, 1952). Larus argentatus breeds on Madeira and the Canaries and wanders rarely as far south as the Gulf of Guinea. Any of these species might have straggled to St. Helena, but $L$. fuscus seems the most likely, particularly since Wallace (1973:561) has found this to be the "second commonest sea-bird at all seasons except late summer and early autumn" at Lagos, Nigeria, in the Gulf of Guinea. Furthermore, I was able to examine only a single skeleton of $L$. fuscus, so variation within that species might well include the characters of the St. Helena fossil.

It is rather remarkable that two apparent vagrants (Puffinus griseus and Larus sp.) were found as fossils on St. Helena.
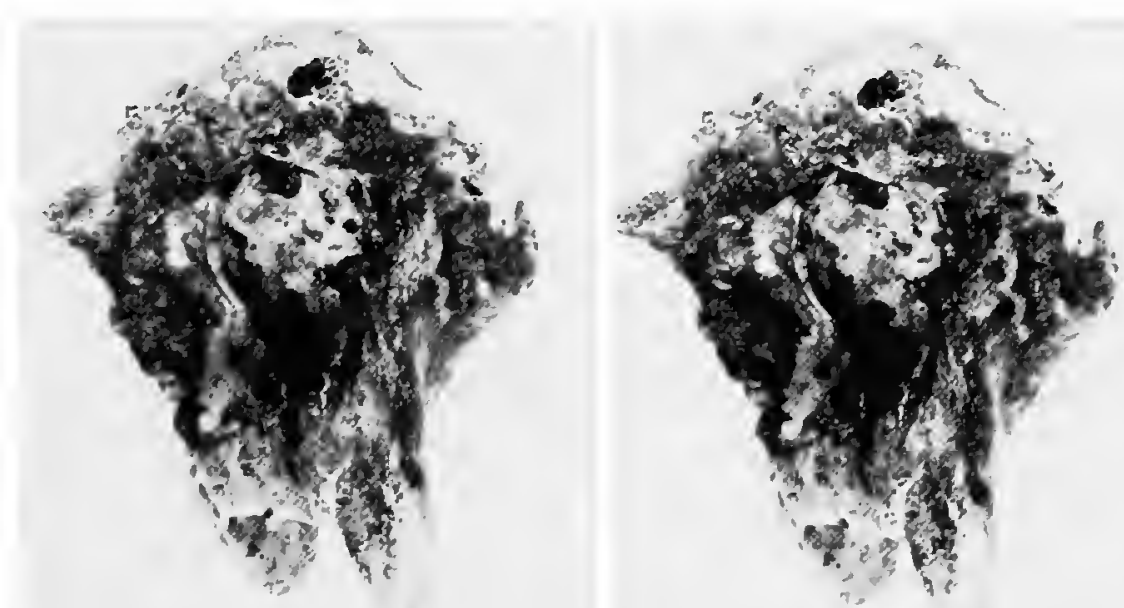

Figure 8.-Stereophotographs of the proximal end of a right humerus of Larus sp. (USNM 176721) from the Dry Gut deposits; anconal view, twice natural size. 


\section{Genus Anous}

\section{Anous stolidus and Anous tenuirostris}

Although both of these species of noddy terns still occur at St. Helena in fair numbers and breed on cliffs and offshore rocks and islets, there is not one bone in any of the deposits that may be ascribed to either species. The same was true at Ascension Island (Olson, in press). As in the case of the tropicbirds, this absence from the fossil record is best attributed to the nesting habits of the birds.

\section{Genus Gygis}

\section{Gygis alba}

The White or Fairy Tern is one of the few species of seabirds still to be found on St. Helena and is perhaps the most delightful and best known of the native birds. It nests on cliffs and in trees in a number of localities around the island but is probably most numerous at Prosperous Bay Valley and in downtown Jamestown. The species occurs elsewhere in the Atlantic on Ascension, Trindade, and Fernando de Noronha.

Gygis alba is poorly represented in the St. Helena fossil collections, no doubt because of its nesting habits. Only five specimens are referable to this species. These are from Prosperous Bay, Dry Gut, Sandy Bay Valley, and include a recent ulna found on the ground near Deep Valley. All of these specimens are markedly smaller than the corresponding elements of Gygis alba from Ascension. Measurements of skins bear out the fact that the Fairy Terns of St. Helena are the smallest of any of the Atlantic populations. There is practically no overlap and subspecific recognition for the St. Helena birds is probably warranted. This will be discussed in greater detail in a paper on the systematics of Gygis (Olson and Farrand, in prep.).

\section{Genus Sterna}

\section{Sterna fuscata}

The Sooty Tern still breeds in relatively small numbers on offshore islets at St. Helena. There is one specimen of the species from Sugarloaf Site 1, one from Site 3, and four from Sandy Bay Valley Site A, establishing its presence in all three time periods.

At Prosperous Bay, I found remains of Sterna fuscata almost entirely within a small circumscribed mound of very superficial loose sediment that appeared to have a relatively high organic content. Bones here were nearly all of Sterna fuscata, were in close association, and were exceptionally well preserved, appearing to be quite recent. To judge from the preservation of the bones of this species in the $\mathrm{BMNH}$ and $\mathrm{MCZ}$ collections, they too must have come from this same deposition or one very similar to it. Over 200 specimens from not less than 23 individuals are represented, most having been collected by Bailey and now at the MCZ. Both Ashmole (1963b) and I found eggshells of this species with the pigmentation still present, a certain indication of their freshness.

The restriction of these remains to this small area of very recent deposits suggests that they may have been laid down subsequent to the other remains at Prosperous Bay. It seems possible that the population of this species may have been increasing only in very recent times. Had it previously been as abundant on St. Helena as it is presently on Ascension, there surely would have been more fossils found in the earlier deposits.

\section{COLUMBIFORMES}

\section{COLUMBIDAE}

From Sugarloaf Site 1, Ashmole (1963b) illustrated two fragments of tarsometatarsi, a fragmentary humerus, and an incomplete tibiotarsus that he identified as columbid. Another proximal end of a tibiotarsus that he felt might "represent another species of columbid" was later identified as the rail Atlantisia podarces (Olson, 1973). In a selection of unidentified fragments in the British Museum collected by the BOU party at the same site, I discovered an additional fragment of columbid humerus. My own repeated visits to Sugarloaf 
Site 1 resulted in the collection of only six other framentary columbid bones-a coracoid, three ulnae, a femur, and a humerus. Columbid remains were absent in all other fossil localities on the island.

In discussing these fossils, Ashmole (1963b:405) concluded that they were not from either of the two introduced columbids on the island (Geopelia striata and Columba liva) and remarked that

there does not appear to be any species of columbid whose humerus, tibia, and tarsus all match those we found: in particular, our humerus is similar in size to those of species which have small tibiae and tarsi, while our specimens of the latter bones are large. ... It is possible that the leg bones are not referable to the same species as the humerus, but I think it more likely that they represent a single endemic species, which was largely terrestrial in habits, with long, strong legs and wings relatively small for its size.

I have reached the same conclusion, namely that all of the 11 available columbid elements are from a single species. These fossils individually and collectively indicate a pigeon of great distinctiveness and one that cannot be placed in any known genus.

\section{Genus Dysmoropelia, new genus}

TYPE.-Dysmoropelia dekarchiskos, new species.

Diagnosis.-A large pigeon with small wings and pectoral girdle and large well-developed hindlimbs. The coracoid is unique in that the head does not project beyond the medial face of the shaft to form a downwardly projecting hook toward the procoracoid process, but instead turns ventrally outward beyond the level of the lip of the glenoid facet; the areas at the base of the procoracoid process and the base of the glenoid facet are depressed so that the ventromedial edge of the shaft below the head forms a narrow, well-defined ridge. The tarsometatarsus is broad and flat, the trochleae widely spread, and the internal intertrochlear notch is wider than in any other columbid genus. The tibiotarsus is large with a wide proximal articulating surface, widely spread cnemial crests, and a long, slender shaft. The neck, trochanter, and shaft of the femur are more flattened than in other genera. The humerus is small relative to the hindlimb, and the shaft is narrow and weak. The ulna is short and much more robust than in other columbids.
ETymology,-From the Greek dysmoros

(illfated) plus pelia (a wild pigeon).

\section{Dysmoropelia dekarchiskos, new species}

\section{Plate 3}

HoLotyPE.- Right coracoid, lacking the sternal quarter and with a little of the upper edge of the procoracoid process broken off. Vertebrate paleontological collections of the National Museum of Natural History (USNM 175955). Color, white with fine blackish vermiculations. Apparently well mineralized. Probably middle Pleistocene in age. Collected from eroded deposits of mixed aeolian calcareous sand and volcanic soil about $500 \mathrm{~m}$ southeast of Sugarloaf Hill (Site 1), St. Helena Island, South Atlantic Ocean, on 22 June 1971 by Storrs L. Olson. Overall length as preserved 26.3 $\mathrm{mm}$, width of shaft at narrowest point 3.3 , depth of shaft 2.3, probable total length 33-34.

Paratypes.- (BMNH S/1963.25.28) distal end of right tarsometatarsus (Ashmole No. 342), (S/1963.25.29) distal half of right humerus (Ashmole No. 337), (S/1963.25.26) worn left tibiotarsus lacking distal end (Kerr No. E4), (S/ 1963.25.27) distal portion of shaft of left tarsometatarsus (Kerr No. E3), (S/1963.25.30) worn proximal end of right humerus. (USNM 175956) left ulna, (I75957 and 175958) proximal fragments of left ulnae, (175959) proximal end of right femur, (175962) distal end of right humerus. All the paratypical material is from the same locality as the holotype.

RANGE.-St. Helena Island, South Atlantic Ocean.

STATUs.-Extinct, known only from the oldest deposit on the island.

Etymology.-From the Greek dekarches (a corporal, literally, a leader of 10 men) plus the masculine diminutive iskos. The specific name stands in apposition and refers to the well-known nickname "Little Corporal" applied to Napoleon Bonaparte-by far the most renowned former resident of St. Helena.

DESCRIPTION.-The coracoid is small, being only slightly larger than in Streptopelia semitorquata but with the shaft very long and delicate. It presents the distinctive peculiarities mentioned in the generic diagnosis; also, the glenoid facet is very prominent, in lateral view recurving ventrally 
well beyond the line of the shaft. The procoracoid process is thin, delicate, and strongly recurved. Only the uppermost part of the sternocoracoidal impression remains on the type, but this has a more prominent ligamental scar on the internal edge than is seen in most pigeons.

The tarsometatarsus is quite large and is as wide or wider than in such large pigeons as Columba junioniae and Leucosarcia melanoleuca. The shaft and distal end are markedly flattened, the trochleae in distal view lying almost in the same plane. The inner trochlea is very wide and is not rotated as far posteriorly as in most columbids. The scar for the hallux is extremely deep and conspicuous, extending high up on the shaft. Width across trochleae (No. 342) with wing of inner trochlea missing $9.3 \mathrm{~mm}$, width of shaft above hallux 4.2, depth at same point 2.3.

The tibiotarsus No. $\mathrm{E} 4$ is porous proximally and is probably from a juvenile. It is large, long, and slender, somewhat resembling such terrestrial genera as Gallicolumba and Leucosarcia. The proximal articular area is wide and in proximal view is squared, not elongated anteroposteriorly as, for instance, in Columba. The tibiotarsus in no other species of pigeon quite duplicates its proportions. The inner and outer cnemial crests are widely separated, with the outer being markedly prominent. Probable total length about $70-75 \mathrm{~mm}$, proximal width behind cnemial crests 7.8 , width of shaft 3.4 .

A proximal half of a right femur (USNM 175959 ) is nearly the size of that of Columba palumbus but of a much different conformation. In proximal view the whole area of the neck and trochanter is flatter and more elongated than in existing pigeons. The shaft, too, is flatter, being especially compressed on the medial side below the head. Posteriorly, the iliac facet overhangs the shaft to form a prominent lip, much betterdeveloped than in the other columbids seen. The condition of the femur of Dysmoropelia is approached in some respects by the ground-dwelling genera Gallicolumba and Geotrygon but the similarities are not great.

In humerus No. 337 the distal end is rather expanded but tapers sharply back to the very weak, slender shaft. This conformation is not duplicated in any genus of living pigeon. The impression of the brachialis anticus is deep, distinct, and elon- gate, unlike the rounded impression of Columba. The ectepicondylar prominence is exceptionally well developed and is much lower on the shaft than in Columba and most other pigeon genera. Distal width $10.0 \mathrm{~mm}$, width of shaft at narrowest point 4.0 , depth of shaft 3.5 . The proximal humeral fragment is too worn to be of great value. It is roughly comparable in size to that of a small example of Columba livia but differs in that the head is flatter and not as bulbous, and the ligamental furrow is shallower and more nealy perpendicular to the shaft. A distal portion of a right humerus (USNM 175962) is so fragmentary and worn that I can only tentatively assign it to this species. It is larger than humerus 337 , but in the position of the ectepicondylar process and brachial depression conforms fairly well with it.

The ulna USNM 175956 is nearly complete but lacks the olecranal area. It is short with a very heavy shaft-heavier than in species with much longer ulnae. The internal condyle is also robust. The tendinal groove is deep and nearly parallel to the shaft, unlike other columbid genera in which this groove angles ventrally. Probable total length 51-52 mm, width of shaft at midpoint 3.5, depth of shaft 4.2. The ulnae USNM 175957 and 175958 are only proximal portions and are too fragmentary to be of much diagnostic value; both are slightly smaller than the more complete specimen.

Discussion.-The former presence of an endemic pigeon on St. Helena is perhaps not too surprising in view of the relative facility with which columbids have colonized islands in the Pacific and Indian oceans. Dysmoropelia was a most peculiar and distinctive bird and considering the disproportionately small wings and pectoral girdle in relation to its otherwise large size, it was probably flightless. No other known columbiform bird besides the Dodos and Solitaires has evolved anything like an equivalent condition.

The relationships of Dysmoropelia are obscure. I have compared it with the six columbid genera found in Africa (Columba, Streptopelia, Aplopelia, Turtur, Oena, and Treron) and also with Ectopistes, Zenaida, Turacoena, Macropygia, Chalcophaps, Phaps, Ocyphaps, Pelrophassa, Geopelia, Leucosarcia, Columbina, Scardafella, Claravis, Leptotila, Geotrygon, Starnoenas, Caloenas, Gallicolumba, Goura, Phapitreron, Ptilinopus, Ducula, 
and Hemiphaga. None shows the peculiarities of Dysmoropelia.

It seems most likely that the ancestors of $D y s$ moropelia arrived at St. Helena from Africa, so it would probably be most fruitful to discuss its possible relationships with African genera. Members of the genus Columba are large, as is Dysmoropelia, have excellent dispersal ability, have done well at colonizing islands, and would seem very reasonable candidates for having given rise to Dysmoropelia. But Dysmoropelia shows no similarity to Columba in any of its elements, and that genus may be eliminated from consideration with some confidence. The same applies to Treron. Of the six African columbid genera, Dysmoropelia seems closest to Streptopelia. The tarsometatarsus (which is the only element of Dysmoropelia showing much similarity to living forms) is similar to that of Streptopelia but differs in being larger, wider, and flatter, and in having the trochleae spread farther apart. Doves of the genus Streptopelia have colonized the Canaries, Madeira, Madagascar, Aldabra, the Seychelles, the Comoros, and other islands in that area, thus demonstrating some ability to cross expanses of open water. Dysmoropelia may possibly be a much enlarged, extremely modified, terrestrially adapted derivative of a
Streptopelia-like ancestor, but the differences between the two genera are great and any relationship between them must be considered only hypothetical.

Dysmoropelia is probably the oldest, and certainly the most divergent from its ancestral stock, of any of the terrestrial birds of St. Helena. It occurs very uncommonly in the fossil record, and then only in the oldest deposit. That it was not found at either of the more productive sites at Prosperous Bay and Dry Gut indicates that it probably became extinct naturally before those deposits were formed.

Almost certainly the "small kind of blue dove" observed by Forster (see Ashmole, 1963b:405) on St. Helena in the 1770 s was the introduced species Geopelia striata and not Dysmoropelia. It may be recalled that introductions had been made very early in the history of St. Helena and that van Linschoten (Tiele, 1885:255) reported "Hennes, Partridges, and Doves, by thousands" in 1589 and Mundy (Temple, 1914:328) found "store of little speckled ginney Henns, partridges and Pigeons" in 1634. There can be little doubt that these were all introduced species and that Dysmoropelia had been long extinct before Forster ever set foot on St. Helena.

\section{CUCULIFORMES}

\section{CUCULIDAE}

In the collections forwarded to the $\mathrm{MCZ}$ by Loveridge was a small vial containing a few scraps of bird bones found at Prosperous Bay. Loveridge informed me (in litt.) that these were collected by Bailey. Most of the identifiable fragments are from Pelagodroma marina, but one regrettably incomplete humerus is of a bird quite different from any other yet described from the island. It agrees in every major aspect with the Cuculidae but is distinct from any of the known taxa of that family. Despite the fragmentary nature of the specimen, I feel a description is warranted, since it definitely represents an unknown element in the avifauna of St. Helena.

\section{Genus Nannococcyx, new genus}

Type.-Nannococcyx psix, new species. Diagnosis.-Agrees with the Cuculidae in pos- sessing a small pneumatic foramen below the internal tuberosity; in the position, shape, and extent of the muscle scars distal to the pneumatic foramen and along the internal edge of the bicipital crest ("attachment of supraspinatus" and "infraspinatus" of Howard, 1929); in the position of the line of the attachment of M. latissimus dorsi anterioris and the scar for M. pectoralis; in the conformation of the ligamental furrow and the curved line delimiting the bicipital surface; and in the position of the nutrient foramen. It differs from other genera of cuckoos in its much smaller size, being considerably smaller than any of the species of Chrysococcyx examined (C. cupreus, $C$. caprius, C. klaas, $C$. basalis). Also, the internal tuberosity is narrower and more delicate in all views. This seems to result mainly from a reduction of the external side of this process so that the anconal surface is smaller, with its long axis more parallel with the shaft. The pneumatic foramen is 
located less distally, being almost entirely obscured by the internal tuberosity when viewed anconally. The area distal to the pneumatic foramen (containing the "supraspinatus" attachment) is somewhat more excavated, making the bicipital crest narrower and more distinct.

EтумоLogy.-From the Greek nannos (dwarf) plus $\operatorname{coccyx}$ (cuckoo).

\section{Nannococcyx psix, new species \\ Plate 4}

HoLotype.-Right humerus lacking the distal end, head, external tuberosity, and much of the deltoid crest (MCZ 7217). Collected at Prosperous Bay Valley, St. Helena Island, South Atlantic Ocean, on 15 February 1970 by John William Bailey and forwarded to the MCZ by A. Loveridge. The bone is dark tan in color, unmineralized, and of recent age. The total length of the fragment, as is, is about $14.2 \mathrm{~mm}$, and the shaft width at the nutrient foramen is about $1.5 \mathrm{~mm}$.

Paratypes.-None.

Rance.-St. Helena Island, South Atlantic Ocean.

Status.-Extinct; presumably extirpated after 1502.

ETymology.--From the Greek psix (a crumb, in allusion to the fragmentary nature of the type).
Diagnosis.-As for the genus.

Discussion.-The relationships of Nannococcyx are for the moment completely hypothetical. Chrysococcyx is a very possible ancestor as four of its species inhabit Africa, are of small size, tend to be migratory, and in the African region have at least reached the islands of Príncipe and São Thomé in the Gulf of Guinea, thus demonstrating some ability for overwater colonizations.

Certain cuckoos, including some of the Australasian species of Chrysococcyx, perform extensive overwater migrations and are known from many of the islands of the South Pacific. The presence of a cuckoo on St. Helena then, while not exactly expected, is not unreasonable.

Further material might perhaps show Nannococcyx to be inseparable from Chrysococcyx, but other than the small size there is no morphological evidence as yet to support a relationship to Chryso$\operatorname{coccyx}$ as opposed certain other genera of cuckoos.

It is quite possible that Nannococcyx was a larger bird than the single humerus would indicate, particularly if its wings were undergoing reduction similar to that seen in Upupa antaios. Nannococcyx psix was probably a forest bird, which accounts for its near absence from the fossil record. Naturally, it could not have survived the deforestation of St. Helena and consequently perished.

\section{CORACIIFORMES}

\section{UPUPIDAE}

\section{Genus Upupa}

The first notice of a hoopoe on St. Helena came from Ashmole (1963b:405), who identified and illustrated a left humerus from the Dry Gut deposits that was said to be "virtually indistinguishable" from that of Upupa epops. Ashmole assumed that this specimen was not merely of a vagrant and that the species was a native of the island. He was correct on all counts, insolar as the material permitted. The humerus is indeed from a hoopoe and does not differ greatly from U. epops. Fortunately, I was able to collect a good deal more material, representing most of the skeleton of this bird, and this indicates that the St. Helena hoopoe was a species quite distinct from that of the mainland.

\section{Upupa antaios, new species}

Plates 5, 6

HoLotype.-Incomplete skeleton consisting of a cranium with most of the dorsal portion missing; an incomplete section of the rostrum with four associated small fragments; the jugal bars, palatines, and a pterygoid (all disarticulated); complete mandible; left ulna, radiale, ulnare, and carpometacarpus; left lemur; right and left tibiotarsi; two pedal phalanges; one vertebral and one sternal rib; three caudal vertebrae, and the pygostyle. Vertebrate paleontological collections of the Na- 
tional Museum of National History (USNM 175936). The bones range in color from rich brownish-orange to light tan (those portions that were exposed to the air are whitish) and do not appear mineralized. Collected on the surface of and a few centimeters beneath the surface of recent sediment deposits on the west side of the lower portion of Prosperous Bay Valley, St. Helena Island, South Atlantic Ocean, on 8 and 13 July 1971 by Storrs L. Olson. The cranium and right tibiotarsus were found exposed on the surface, and I later returned to the same site and unearthed the remainder of the elements, all of which are certainly from one and the same individual.

Paratypes.-Prosperous Bay: a right and left tibiotarsus (USNM 175937 and 175938) of different size and from different sides of the gorge; left femur (USNM 175944).

Dry Gut: left humerus (BMNH S/1963.25.18Ashmole No. 240); left femur (BMNH S/1963. 25.25-Ashmole No. 237) mentioned by Ashmole (1963b:393) as an unidentified specimen; right tibiotarsus (USNM-175393); proximal end of right ulna (USNM 175940); distal end of right ulna (USNM 175961); right tarsometatarsus lacking distal end (USNM 175943); decomposed left hu- merus lacking distal end (USNM 175941), and right and left humeri lacking proximal ends and found in association (USNM 175942).

Counting the type, there were at least three and probably four individuals from Prosperous Bay and at least three from Dry Gut.

RANGE.-St. Helena Island, South Atlantic Ocean.

Status.-Extinct; presumably died out after 1502. ETYMology.-In Greek mythology, Antaios (Latin, Anteus) was a giant wrestler, son of Gaea, whose strength was maintained as long as he was in contact with the earth and who was finally vanquished by Hercules. The St. Helena hoopoe was likewise a giant of its kind and as necessarily committed to the earth.

Diagnosis.-A very large Upupa with cranial and hindlimb elements longer and much heavier than in $U$. epops but with the distal wing elements much more reduced.

DESCRIPTION.-Upupa antaios was compared with 26 skeletons of Upupa epops from France, Egypt, Cameroons, Congo, Rhodesia, Thailand, China, and Tibet (Table 7).

The mandible of $U$. antaios is larger and heavier throughout, and is much more noticeably decur-

TABLE 7.- Size comparison $(\mathrm{mm})$ of Upupa epops $(\mathrm{n}=26)$ and $\mathrm{U}$. antaios, new species (measurements in parentheses are taken from specimens other than the holotype of $U$. antaios; shaft widths taken at midpoint; *estimated)

\begin{tabular}{|c|c|c|c|c|}
\hline \multirow[b]{2}{*}{ Measurement } & \multicolumn{3}{|c|}{ U.epops } & \multirow[t]{2}{*}{$U$. antaios } \\
\hline & range & mean & s.d. & \\
\hline Mandible length (chord) & $60.6-73.4$ & 66.0 & 4.10 & 81.4 \\
\hline Mandible width at symphysis & $3.0-4.4$ & 3.7 & 0.40 & 4.9 \\
\hline 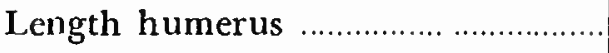 & $31.0-36.6$ & 34.0 & 1.44 & $(33.1)$ \\
\hline Proximal width humerus & $9.6-11.7$ & 10.7 & 0.56 & $\left(10.3^{*}\right)$ \\
\hline Shaft width humerus ............... & $2.8-3.6$ & 3.3 & 0.16 & $(3.1,3.1,3.2)$ \\
\hline Distal width humerus ....... & $7.1-8.7$ & 8.0 & 0.38 & $(8.2,8.3,8.3)$ \\
\hline 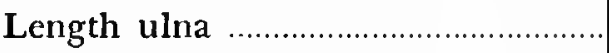 & $42.5-49.7$ & 45.7 & 1.81 & 39.4 \\
\hline Length carpometacarpus ........ & $19.4-23.3$ & 21.1 & 0.90 & 17.5 \\
\hline 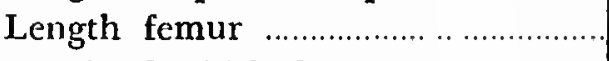 & $21.2-25.8$ & 23.7 & 1.14 & $28.1\left(25.5,28.5^{*}\right)$ \\
\hline Proximal width femur & $4.1-5.1$ & 4.7 & 0.28 & $5.8(5.2,6.2))$ \\
\hline Shaft width femur ................... & $1.9-2.4$ & 2.1 & 0.15 & $2.5 \quad(2.3,2.6)$ \\
\hline Distal width fernur ......... & $4.1-5.0$ & 4.6 & 0.24 & $6.0 \quad(5.4)$ \\
\hline Length tibiotarsus & $33.0-40.6$ & 35.8 & 1.75 & $40.1\left(38.1^{*}, 39.6^{*}, 40.5\right)$ \\
\hline Proximal width tibiotarsus & $3.5-4.6$ & 4.1 & 0.28 & 5.6 \\
\hline Shaft width tibiotarsus ......... & $1.5-2.2$ & 1.8 & 0.16 & $2.4(2.1,2.3,2.3)$ \\
\hline Distal width tibiotarsus ....................... & $3.0-4.1$ & 3.6 & 0.25 & $4.7(4.5,4.6,4.6)$ \\
\hline Proximal width tarsometatarsus ...... & $3.6-5.0$ & 4.3 & 0.31 & $(5.9)$ \\
\hline Shaft width tarsometatarsus ........... & $1.5-2.2$ & 1.8 & 0.18 & $(2.6)$ \\
\hline
\end{tabular}


ved. In dorsal view the surangular area is flared farther outward. The internal articular and postarticular processes are better developed, the latter curving more strongly upward than in $U$. epops. The cranium is larger and wider, with the parietal fossae more extensive and deeper than in $U$. epops.

The humerus is essentially identical to that of $U$. epops in size; the shaft is somewhat more slender than in most specimens of $U$. epops and the distal end more expanded and flattened. The ridge delimiting the muscle attachment on the deltoid crest is more prominent in $U$. antaios.

The ulna is shorter and stouter than in any specimen of $U$. epops and has the papillae for the attachment of the secondaries more prominent and placed closer together. The radiale and ulnare are identical in size to smaller specimens of $U$. epops but are a bit heavier and more sculpted. The carpometacarpus is shorter and stockier than in $U$. epops, metacarpal II is heavier, metacarpal III is more noticeably bowed, and the intermetacarpal space is shorter and rounder; the carpal trochlea is distinctly smaller than in $U$. epops.

The femur of the type and that from Dry Gut are both much larger and heavier than in $U$. epops. The other femur from Prosperous Bay is slightly less than the maximum for U. epops but is heavier, with a more expanded distal end than in specimens of $U$. epops of comparable size. The pneumatic foramen in the trochanter is variable in size in $U$. epops but is small in all three specimens of $U$. antaios. In posterior view the neck is more excavated, sharply delimiting the head of the femur in $U$. antaios. The popliteal and intercondylar fossae are deeper and the external condyle larger than in $U$. epops.

The referred tibiotarsi of $U$, antaios are somewhat smaller than those of the type but all are larger and especially heavier than in $U$. epops, with stouter shafts and wider articulations. In only one of the 26 specimens of $U$. epops measured were the tibiac longer than those of the type of $U$. antaios, but these were very much more slender. In $U$. antaios the condyles are larger and more widely separated and the anterior intercondylar fossa is deeper. The point of attachment of the ligamental bridge on the medial side of the shaft above the internal condyle is a somewhat lengthened crest in $U$. epops and is reduced to a rounded papilla in $U$. antaios. The inner cnemial crest is better developed and the posterior rim of the internal condyle is more pronounced in $U$. antaios.

The tarsometatarsus of $U$. antaios is much larger with a broader, heavier, and more excavated shaft than in $U$. epops.

The pygostyle (mirabile dictu) of $U$. antaios is heavier, with the crest not as long and slender and the base wider and more flattened on the ventral surface than in $U$. epops.

Discussion.-There can be little doubt that Upupa antaios was of African origin and probably derived directly from Upupa epops. It was a large hoopoe but with much restricted, if not entirely abrogated, powers of flight. There is enough material of the species to permit some crude but interesting calculations of its size and wing-loading, which can then be compared with those of $U$. epops.

The wing areas of three specimens of $U$. epops were determined by spreading the wings on graph paper ruled in millimeters, tracing around them, and counting the number of squares thus outlined. The wing areas were 270,295 , and $308 \mathrm{~cm}^{2}$, for an average of $291 \mathrm{~cm}^{2}$. The weight of ten fresh specimens of $U$. epops ranged from 56.6 to $79.0 \mathrm{~g}$, for an average of $66 \mathrm{~g}$.

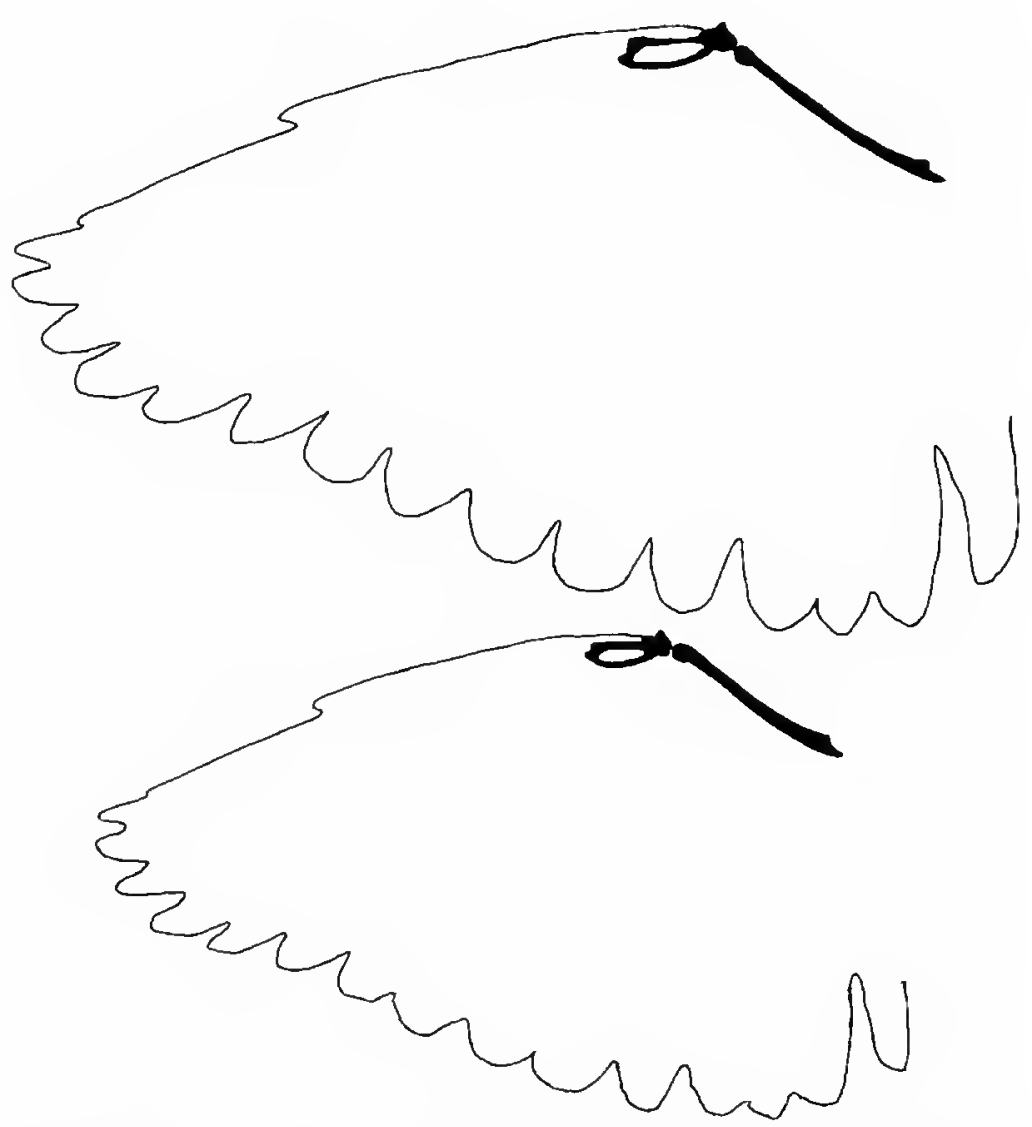

Figure 9.-Wing area of Upupa epops (above) contrasted with the estimated wing area of $U$. antaios (below) (figure reduced 60 percent). 
By reducing a projected photograph of the wing of $U$. epops until the ulna and carpometacarpus were the same length as those of $U$. antaios (Figure 9 shows the relative difference in the size of the wings), an estimated wing area of $200 \mathrm{~cm}^{2}$ was obtained for $U$. antaios. This assumes that the flight feathers of $U$. antaios were reduced by the same proportions as the bones, whereas in fact they may have been reduced even further. The estimate of $200 \mathrm{~cm}^{2}$ therefore probably gives the maximum possible value for the wing area of $U$. antaios.

The length of the femur of $U$. antaios is 19 percent greater than the average for $U$. epops, while the widths of the hindlimb elements average 33 percent larger. Using these figures and considering that volume increases as the cube of linear dimensions, a weight of 111 to $155 \mathrm{~g}$ is estimated for $U$. antaios. However; as its pectoral muscles were no doubt smaller than in $U$. epops, an adjustment must be made. The average weight of the breast muscles of four specimens of $U$. epops was about $10 \mathrm{~g}$. If we arbitrarily assume that the breast muscles of $U$. antaios were negligible in weight, the adjusted estimated weight of $U$. antaios would fall in the range of 101 to $145 \mathrm{~g}$, with the heavier extreme being the more likely.

The wing loading (cf. Clarke, 1971) of U. epops averages $0.23 \mathrm{~g} / \mathrm{cm}^{2}$ while that of $U$. antaios would be at least 0.51 to $0.73 \mathrm{~g} / \mathrm{cm}^{2}$-obviously a much higher loading for the latter. To make the data comparable to those in Poole (1938), the wing area per gram in $U$. epops averages $4.4 \mathrm{~cm}^{2} / \mathrm{g}$ versus 1.98 to $1.38 \mathrm{~cm}^{2} / \mathrm{g}$ for $U$. antaios. As Poole lists a number of birds with a greater "wing loading" than $U$. antaios, it cannot be stated with any degree of certainty from these data that $U$. antaios was completely flightless. Nevertheless its flying ability had to have been considerably limited compared to that of $U$. epops.

The presence on St. Helena of a hoopoe, a bird characteristic of grassland, glades, or open forest, is another argument against the island's having been entirely covered with heavy forest in preEuropean times.

The fairly rich fauna of terrestrial invertebrates on St. Helena would have provided forage for $U$. antaios. Among this fauna, St. Helena can boast the world's largest earwig (Labidura herculeana, Dermaptera), which lives in burrows and under stones in dry soil and which attains a total length of at least $78 \mathrm{~mm}$ and probably more (Brindle, 1970). The very long probing bill of $U$. antaios would have been useful in preying on this species, and it takes no great imagination to envision the world's largest hoopoe conquering the world's largest earwig, thereby reversing the mythological order in having Antaios triumph over Hercules.

\section{PASSERIFORMES}

No fossils of passerine birds were collected and there are no passerines endemic to St. Helena today, although five species, Acridotheres tristis, Serinus flaviventris, Foudia madagascariensis, Padda oryzivora, and Estrilda astrild have been successfully introduced. However, in view of the fact that hoopoes, cuckoos, pigeons, plovers, and rails naturally colonized the island, and that three different passerine stocks have colonized the more remote and less hospitable islands of Tristan da Cunha and Gough, it seems likely that there was a passerine component in the avifauna of St. Helena. That passerines are not represented in the present or fossil faunas may be attributed to early deforestation and the remote chance of small, largely arboreal species being preserved as fossils.

\section{Discussion}

The effort of collecting and identifying every specimen possible was fully repaid by the information yielded by a quantitative analysis of these specimens. A summary of the numbers of specimens and individuals of each species by locality is pre- sented in Table 8. It can be seen here that there are considerable differences in species composition and abundance between the deposits of different ages.

Changes in species composition and abundance 
are most strikingly illustrated by the Procellariiformes (Figure 10). In the oldest deposit (Sugarloaf Site 1), Pterodroma rupinarum and Bulweria bifax are present in about equal numbers and together compose over 40 percent of the population of Procellariiformes present at that time. Puffinus pacificoides and P. lherminieri are present in lower numbers. Pelegodroma marina is the most abundant species of all.

The middle deposits show an entirely different picture. Pterodroma rupinarum is much the most abundant species, Puffinus pacificoides is absent, and $P$. lherminieri and Bulweria bifax are nearly so.

In the recent deposits the populations are yet again different. Puffinus pacificoides is still absent; Bulweria bifax is known from nine bones only and is altogether absent from the rich Prosperous Bay deposits. The greatest contrast, however, is between Pterodroma rupinarum, which decreased noticeably, and Puffinus lherminieri which became the dominant species, exceeding in numbers all the others combined.

It is difficult to interpret the information concerning the frigatebirds, boobies, and terns. These birds are present only in the recent deposits (with the exception of two bones of Sula dactylatra, two of Sterna fuscata, and one of Gygis alba from earlier deposits). As mentioned, the bones of frigatebirds are for the most part very thin and fragile and thus liable to deteriorate quickly and not be preserved in the older deposits. However, were frigatebirds as abundant in the earlier periods as they were in the recent one, one might expect to find

TABLE 8.-Summary of abundance of fossil specimens from St. Helena by species and locality (all specimens in the USNM, MCZ, and BMNH collections are included; for each site, the left-hand column refers to the actual number of specimens collected, and the italicized column refers to the minimum number of individuals; associated skeletons were counted as one specimen)

\begin{tabular}{|c|c|c|c|c|c|c|c|c|c|c|c|c|c|c|c|c|}
\hline \multirow[b]{2}{*}{ Species } & \multicolumn{2}{|c|}{$\begin{array}{l}\text { Oldesı } \\
\text { Period }\end{array}$} & \multicolumn{6}{|c|}{ Middle Period } & \multicolumn{6}{|c|}{ Recent Period } & \multirow{2}{*}{\multicolumn{2}{|c|}{ Totals }} \\
\hline & \multicolumn{2}{|c|}{$\begin{array}{l}\text { Sugarloaf } \\
\text { (Sile 1) }\end{array}$} & Dry & Gut & \multicolumn{2}{|c|}{$\begin{array}{l}\text { Sugarloaf } \\
\text { (Sile 3) }\end{array}$} & \multicolumn{2}{|c|}{$\begin{array}{c}\text { Sandy Bay } \\
\text { (Site B) }\end{array}$} & \multicolumn{2}{|c|}{$\begin{array}{c}\text { Prosperous } \\
\text { Bay }\end{array}$} & \multicolumn{2}{|c|}{$\begin{array}{l}\text { Sugarloaf } \\
\text { (Site 2) }\end{array}$} & \multicolumn{2}{|c|}{$\begin{array}{c}\text { Sandy } B a y \\
\text { (Sile } A)\end{array}$} & & \\
\hline rupinarum & 182 & 24 & 790 & 82 & 38 & 8 & 10 & 2 & 93 & 13 & 7 & 2 & 25 & 4 & 1145 & 135 \\
\hline Bulweria bifax ........ & 240 & 24 & 12 & 3 & 1 & 1 & & & & & & & 9 & 3 & 262 & 31 \\
\hline Puffinus pacificoides .... & 73 & 8 & & & & & & & & & & & & & 73 & 8 \\
\hline Puffinus lherminieri ...... & 68 & 10 & 19 & 3 & & & 2 & 1 & 848 & 90 & 86 & 16 & 10 & 2 & 1033 & 122 \\
\hline Puffinus griseus ....... & 2 & 1 & & & & & & & & & & & & & 2 & 1 \\
\hline Oceanodroma castro ...... & 3 & 2 & 5 & 2 & 1 & 1 & & & 13 & 6 & 27 & 6 & & & 49 & 17 \\
\hline Pelagodroma marina. & 313 & 48 & 83 & 12 & 1 & 1 & & & 163 & 26 & 187 & 19 & 26 & 5 & 773 & 111 \\
\hline Phaethon aethereus ...... & & & & & & & & & 3 & 1 & & & & & 3 & 1 \\
\hline 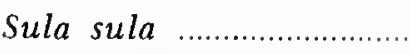 & & & & & & & & & 9 & 3 & & & & & 9 & 3 \\
\hline 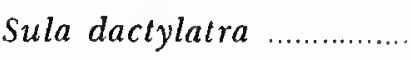 & & & 2 & 1 & & & & & 17 & 5 & & & & & 19 & 6 \\
\hline Fregala minor ............... & & & & & & & & & 48 & 8 & 1 & 1 & & & 49 & 9 \\
\hline Fregata a. Irinitatis ...... & & & & & & & & & 899 & 56 & 2 & 1 & 6 & 1 & 907 & 58 \\
\hline Allanlisia podarces ........ & 3 & 1 & 11 & 3 & & & & & 20 & 4 & & & 8 & 1 & 42 & 9 \\
\hline Porzana astrictocarpus & & & 22 & 4 & & & & & 21 & 5 & & & 10 & 4 & 53 & 13 \\
\hline Charadrius & & & & & & & & & & & & & & & & \\
\hline sanctaehelenae ....... & & & 1 & 1 & 1 & 1 & & & 2 & 1 & & & & & 4 & 3 \\
\hline 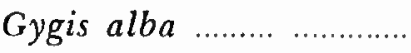 & & & 1 & 1 & & & & & 2 & 1 & & & 1 & 1 & 4 & 3 \\
\hline Sterna fuscata ..................... & 1 & 1 & & & 1 & 1 & & & 201 & 23 & & & 4 & 2 & 207 & 27 \\
\hline 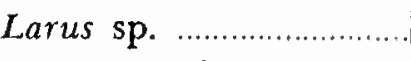 & & & 1 & 1 & & & & & & & & & & & 1 & 1 \\
\hline Dysmoropelia & & & & & & & & & & & & & & & & \\
\hline dekarchiskos .... ............ & 11 & 3 & & & & & & & & & & & & & 11 & 3 \\
\hline Nannococcyx psix & & & & & & & & & 1 & 1 & & & & & 1 & 1 \\
\hline Upupa antaios ........... & & & 9 & 3 & & & & & 4 & 3 & & & & & 13 & 6 \\
\hline Totals $\ldots \ldots \ldots$ & 896 & 122 & 956 & 116 & 43 & 13 & 12 & 3 & 2344 & 216 & 314 & 47 & 95 & 22 & 4660 & 569 \\
\hline
\end{tabular}




\section{$\begin{array}{lll}\text { OLD } & \text { MIDDLE }\end{array}$}

PIERODROMA RUPINARUM

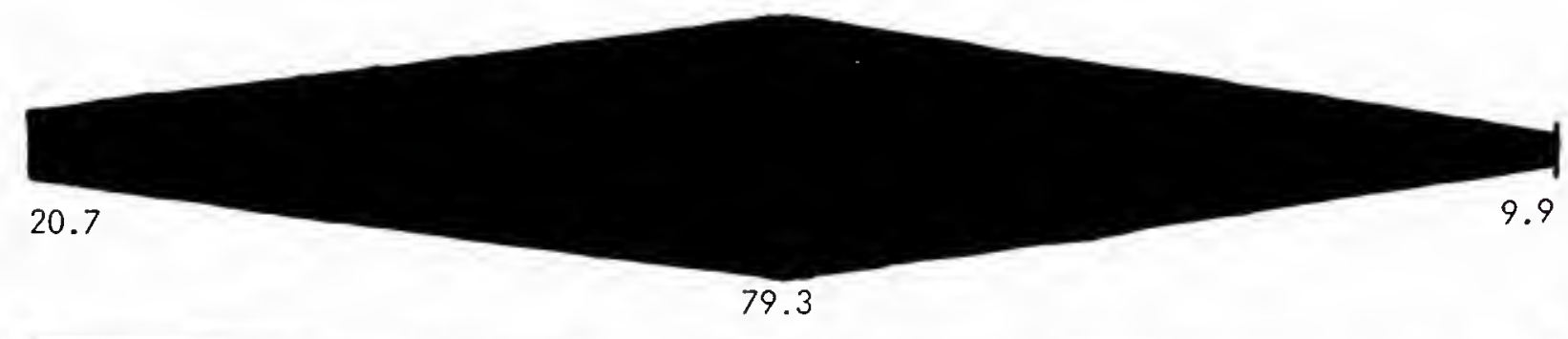

BULWERIA BIFAX

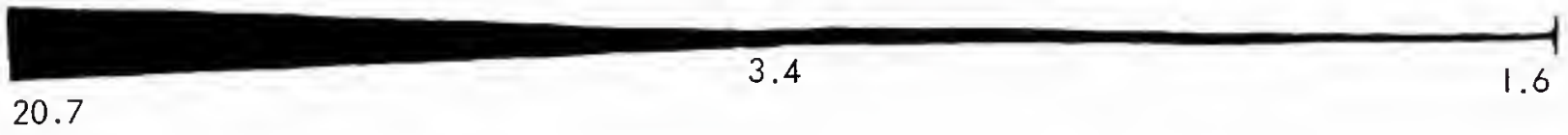

PUFFINUS PACIFICOIDES

6.9

PUFFINUS LHERMINIERI

8.6

3.4

56.2

CCEANODROMA CASTRC

1.7

2.6

6.3

PELAGCDROMA MARINA

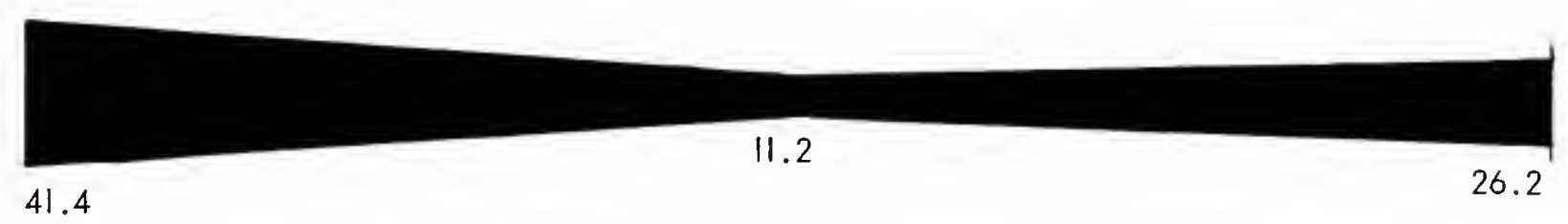

FIGURE 10.-Diagram demonstrating the Pleistocene changes in the populations of procellariiform birds at St. Helena. The width of the line is determined by the percent of the total procellariiform population that a species forms at a particular time period. The numbers show the actual percentages.

a few fragments of rostra or other elements of denser bone of these birds. Bones of boobies and terns, on the other hand, should survive at least as well as those of procellariids, and they too are nearly absent from the older deposits.

I believe that these differences in the relative abundance of species are attributable to actual changes in the population structure through time and are not merely a factor of local habitat differences or differential choice of nest sites. Perhaps the best evidence in favor of this is the fact that deposits representing all three time periods are found within a small area near Sugarloaf Hill, and the species composition of each of these correlates with that of deposits of similar age in other parts of the island. Also, the differences between the very rich deposits at Prosperous Bay, which must be representative of the species population structure of the island at the time, and those, for instance, at Sugarloaf Site 1 are much too great merely to be due to local geographic factors.

Pleistocene changes in meteorological conditions and the marine environment around St. Helena could have affected the seabird populations greatly. Hays and Peruzza (1972), in analyzing calcium carbonate oscillations in deep-sea cores taken off the West Coast of Africa, concluded that the trade winds in the Atlantic were stronger during glacial periods than during interglacials. More recently, Parkin (1974) has most convincingly reached the same conclusion from his analyses of aeolian quartz-grains, also from cores taken off western Africa. We have already noted that Muir and Baker (1968) had concluded that the winds 
at St. Helena must have been much more forceful in the past than they are at present. Increased wind stress results in increased upwelling, which in turn increases marine productivity. Conversely, one would expect that during nonglacial periods, such as at present, the decrease in wind strength would ultimately lower the marine productivity of many areas. All the changes in seabird populations observed at St. Helena could, I believe, be explained by such a decrease in productivity and by a progressive warming of the waters around St. Helena in the later part of the Pleistocene. This would have affected the food supply of marine birds, both in quantity of prey items and in the kinds of prey species available.

With such a view in mind we may try to explain the alterations in seabird populations observed at St. Helena. Perhaps the first most notable event was the disappearence of Puffinus pacificoides, which evidently took place at an early date. The complete absence of this species from all but the oldest deposit seemingly can be explained only by its having become extinct naturally before the middle deposits were formed. It is of interest in this regard that no member of its species-group now exists in the Atlantic. That $P$. pacificoides composed only about 7 percent of the procellariiform population in the Sugarloaf Site I deposit suggests that it may already have been on the decline at that time.

Virtually the same fate befell Bulweria bifax, a species that was common in the oldest deposits. Although it did not become quite extinct, its numbers in the later periods are almost negligible. Since no incoming species of procellariids replaced either Puffinus pacificoides or Bulweria bifax, and since it is unlikely that they were decimated by disease, their disappearance must be due to some environmental influence.

The apparent fluctuations in numbers of Pterodroma rupinarum are somewhat enigmatic. I think that there can be little doubt that it was extremely abundant in the middle period, and probably was more abundant at that time than in the older period. This may perhaps be correlated with the loss of Puffinus pacificoides and Bulweria bifax, and with the fact that Puffinus lherminieri had not yet begun to increase. The low numbers of these species may have relieved Pterodroma rupinarum of some of the limitations of competition for food and nest sites, allowing the population to increase. Its apparent decline afterward probably reflects progressive environmental change.

Puffinus lherminieri shows a pattern quite different from those of the other species of procellariiforms, as it formed but an inconsiderable proportion of the individuals in the old and middle periods and then suddenly blossomed forth to become by far the most abundant species in the recent period. Despite the fact that this would at first seem to contradict the other evidence, in the final analysis the history of $P$. lherminieri on the island is also seen to fit perfectly into the theme being developed here. Puffinus lherminieri is actually one of the most tropical of the Procellariidae and, as Harris (1969:152) has shown, is well adapted to irregular food supply, perhaps more so than most other species of Puffinus. For example, "newly hatched $P$. lherminieri could survive up to five days without being fed whereas $P$. puffinus young often die if unfed for two or three days." Thus when conditions at St. Helena were temperate and more favorable to the other species of procellariids, $P$. lherminieri appears to have been able to maintain only a marginal population, but later, when the other species had fallen upon hard times, $P$ lherminieri possessed the adaptations necessary to respond to the new environment, and them flourished.

Changes in the populations of Pelagodroma marina are difficult to discern but there does seem to be a general decline in numbers in the later periods compared to those at Sugarloaf Site 1. The crevice-nesting species Oceanodroma castro occurs only incidentally as a fossil and statistics concerning it are probably not significant. Like $P$. lherminieri, however, it is a tropical species and very likely was not adversely affected by the changes in marine environment.

Ashmole (1963a:340) has shown that the Sooty Tern, Sterna fuscata, nearly always breeds on the warm side of the $23^{\circ} \mathrm{C}$ surface water isotherm and suggested that this fact may be correlated with the distribution of one of its principal prey items, the flying fish Exococtus rolitans, which is found only in water warmer than $22.5^{\circ} \mathrm{C}$. The distribution of E. volitans off the West Coast of Africa fluctuates with the seasonal shifts of the $23^{\circ}$ isotherm in this area (Bruun, 1935). Murphy (1936:80) correlated the distribution of Sula dactylatra with the pres- 
ence of flying fish. On Ascension, the frigatebird Fregata aquila feeds almost exclusively on flying fish, and these fish are likewise one of the main prey items of the boobies there (Stonehouse 1962:120).

The $23^{\circ}$ isotherm usually lies between Ascension Island and St. Helena but there are annual shifts in its latitude so that St. Helena is barely included on the warm side of this isotherm for part of the southern summer, while Ascension remains on the warm side throughout the year (Stonehouse, 1962). Sooty Terns breed at St. Helena when the island is on the warm side of the isotherm, and since this occurs only once a year, the species has an annual breeding cycle on St. Helena, whereas at Ascension it breeds on a $91 / 2$-month cycle and egg laying may begin at any time of year (Ashmole, 1963a).

It seems quite possible that the annual shift of the $23^{\circ}$ isotherm may not in the past have extended far enough to the south to include St. Helena, so that during glacial periods the island would have remained on the cold side of the isotherm throughout the year. A warming trend and decreased winds later in the Pleistocene, while probably decreasing the overall level of productivity of the waters about St. Helena to the detriment of most of the procellariiforms, would also have been accompanied by a more southerly shift in the $23^{\circ}$ isotherm to include St. Helena for part of the year, permitting the island to be colonized by an entirely different group of marine birds. Thus, at the time man arrived at St. Helena, the island appears to have been in the process of shifting from a largely subtropical avifauna composed mainly of species of Procellariiformes, to a more purely tropical one like that of Ascension, composed of terns, boobies, and frigatebirds, which feed principally on flying fish. In this light it is worth noting that the only procellariiform birds known from Ascension are the tropical species Puffinus lherminieri and Oceanodroma castro.

The only land birds in the Sugarloaf Site 1 deposits are Dysmoropelia dekarchiskos and Atlantisia podarces, and these species, it may be noted, are the most divergent from their respective parental stocks of any of the land birds of St. Helena. While the Sugarloaf Site 1 deposits are probably not comprehensive enough for one to be sure that the other species of land birds were not present at that time, the remaining deposits are sufficiently large to suggest that the absence of Dysmoropelia from them is due to its having naturally become extinct at some time after the deposition of the Site 1 bones.

Where their ancestry is apparent, the land birds of St. Helena have been derived from colonizations from Africa, and there is no evidence of a New World element in the terrestrial avifauna. Four of the endemic land birds had increased appreciably in size compared to their presumed ancestors. Only Porzana astrictocarpus and Nannococcyx remained about the same or possibly decreased in size. All species for which there is sufficient material exhibit flightless characters or at least a tendency toward reduced pectoral muscles in the case of the Charadrius.

We know from old accounts (see pp. 4-5) that hogs, dogs, cats, and rats appeared soon after the arrival of man. The effects of these predators without check or restraint on a naive population of defenseless birds must have been almost immediate. Hogs can be counted to eat anything organic and could easily have dug nesting petrels from their burrows and consumed the eggs of ground-nesting birds. Dogs would likewise have taken any birds they could capture. The studies of Kepler (1968) and Fleet (1972) have shown that rats will feed directly on living seabirds, as well as on their eggs, and are a very significant cause of mortality in some species.

Cats, of course, are notorious bird killers. Boddom-Whetham (1972:233) has remarked that Upupa epops in Africa is "easily liquidated by the domestic cat" and seems to be "the most easily caught of all birds." Upupa antaios, with its negligible flying ability, must have been particularly vulnerable to cat predation. Some idea of the effect of cats on the former avifauna may be gained from a study of their impact on the few remaining species of birds on St. Helena. To this end, I collected and analyzed 150 scats of feral cats from Prosperous Bay Valley, Dry Gut, Turk's Cap Valley, and Banks Valley. Most of these contained hair and bones of mice and rats. Some included crickets and beetles; a few contained fish; and one even included a large dry kernal of corn (Zea mays). Nineteen of these scats contained either feathers or bones of birds. Of these, seven contained remains of Gygis alba, two contained re- 
mains of Acridotheres tristis, two had bones of Geopelia striata, and one consisted mainly of a bunch of barred feathers of Phaethon aethereus. The rest of the bird remains were not identifiable. The cat that ate the tropicbird must necessarily have been not only resourceful, but strong, since this species is not found in accessible places and its powerful beak would make it an uncomfortable adversary. At any rate, 13 percent of the scats examined contained remains of birds. This seems a high proportion in view of the small numbers of birds now left on St. Helena.

The seven species of native birds that compose the present avifauna of St. Helena (excluding boobies) constitute only 5.8 percent of the total number of fossil specimens recovered, and if Sterna fuscata is eliminated, the remaining six represent only 1.5 percent of the fossil specimens. Thus, the same factors (cliff nesting) that assure the survival of certain species also prevent their being frequently fossilized. The Charadrius was able to persist because it still retained an ability to escape predators by flying and because it was not affected by deforestation.

To the growing volume of literature concerning the factors affecting avian species diversity on islands (habitat diversity, island area, distance from land, etc.), I would like to add a few simple observations. St. Helena and Ascension Island are roughly the same size ( $47 \mathrm{sq} \mathrm{mi}$ vs $38 \mathrm{sq} \mathrm{mi}$ ) and, measured in the direction of the prevailing winds, are nearly equidistant from Africa. St. Helena, with abundant fresh water and a diverse vegetation comprising at least two distinct habitat types, had a minimum of six very different species of land birds. Ascension, which is a nearly barren desert island with scanty vegetation and practically no fresh water, had only one-the rail Atlantisia elpenor, which was probably a scavenger in seabird colonies. The Common Gallinule, Gallinula chloropus, has colonized and established a thriving breeding population on St. Helena within the past few hundred years because there are numerous marshy areas suitable for its existence when it must cope with predators. Three species of gallinules are apparently regular vagrants to Ascension (Olson, 1973), but because there is no suitable habitat, none has persisted. It doesn't take a lot of intricate calculations to see that an island cannot support species for which it has no resources. While it is no doubt true that there will always be a combination of factors that ultimately determines the number of species an island can carry, it is evident that habitat diversity is chief among them.

Dysmoropelia dekarchiskos provides what is perhaps the only paleontological documentation of natural turnover in an insular land bird fauna. Because of the imperfect nature of the fossil record from the oldest deposits on St. Helena, little more can be said about turnover rates on the island except to add that when man appears, the turnover rate increases tremendously.

\section{Epilogue}

I concluded my previous report on the rails of St. Helena and Ascension (Olson, 1973) with a statement indicating that it would be of interest to investigate the paleornithology of other South Atlantic islands. Since then I have been able to conduct such investigations on the island of Fernando de Noronha with notable success, yet with results entirely different from those obtained at St. Helena, since on Fernando de Noronha the presence of native terrestrial rodent (now extinct), among other things, appears to have affected considerably the composition of the avifauna. Thus, each of these little islands holds different insights into the nature and diversity of the organic world and the factors that affect it.

We will perhaps never be so fortunate again to obtain the kind of information afforded by the various bone deposits of St. Helena, but these illustrate that there is a great deal more to insular paleornithology than a simple cataloging of extinct species. The case of St. Helena should serve to emphasize graphically that it is unwise to make generalizations about island avifaunas, either terrestrial or marine, without knowing something of the nature of the fauna before the arrival of man. Paleontological investigations should be an integral part of any faunal survey of an oceanic island. 


\section{Literature Cited}

Ashmole, N. P.

1963a. The Biology of the Wideawake or Sooty Tern Sterna fuscata on Ascension Island. Ibis, 103b:297364.

1963b. The Extinct Avifauna of St. Helena Island. Ibis, 103b:390-408.

Baker, I.

1970. Geological History of Saint Helena in Relation to Its Floral and Faunal Colonization. In La Faune terrestre de l'Isle Sainte-Hélène, première partie. Musee Royal de l'Afrique Central-Tervuren, Belgique-Annales Serie IN- ${ }^{\circ}$, Sciences Zoologiques, $181: 23-36$.

Bannerman, D. A., and W. M. Bannerman

1968. History of the Birds of the Cape Verde Islands. Volume 4 of Birds of the Atlantic Islands. xxxi + 458 pages. Edinburgh: Oliver and Boyd.

Barnes, J.

1817. A Tour through the Island of St. Helena; with Notices of Its Geology, Minerology, Botany, Etc. Etc. 239 pages. London: J. M. Richardson.

Benson, C. W.

1950. A Contribution to the Ornithology of St. Helena, and Other Notes from a Sea-Voyage. Ibis, 92:75-83.

Birch, W. de G., editor

1880. The Commentaries of the Great Afonso Dalboquerque, Second Viceroy of India. Hakluyt Society: Series I, number 62, volume 3, 308 pages. London.

Blofeld, J. H.

1852. Notes on St. Helena. Proceedings of the Geological Society of London, 8:195-196.

Bock, W. J.

1958. A Generic Review of the Plovers (Charadriidae, Aves). Bulletin of the Museum of Comparative Zoology, 118:27-97.

Boddam-Whetham, A. D.

1972. Birds in Orange Free State Gardens. Ostrich, 43: 233-234.

Bourne, W. R. P.

1953. On the Races of the Frigate Petrel, Pelagodroma marina (Latham) with a New Race from the Cape Verde Islands. Bulletin of the British Ornithologists' Club, 73:79-82.

1956. Notes on a Skull of the Genus Bulweria from St. Helena. Bulletin of the British Ornithologists' Club, 76:126-129.

1965. The Missing Petrels. Bulletin of the British Ornithologists' Club, 85:97-105.

1968. The Birds of Rodriguez, Indian Ocean. Ibis, 110: 338-344.

Brindle, A.

1970. Dermaptera. In La Faune terrestre de l'Isle SainteHélène, première partie. Musee Royal de l'Afrique Central-Tervuren, Belgique-Annales Series $I N-8^{\circ}$, Sciences Zoologiques, 181:211-227.

Brodkorb, P.

1963. Catalogue of Fossil Birds, Part I (Archaeopterygi- formes through Ardeiformes). Bulletin of the Florida Slate Museum, Biological siciences, 7:179-293.

Bruun, A.

1935. Flying Fishes (Exocoetidae) of the Atlantic: Systematic and Biological Studies. Number 6 in Dana Report. 106 pages.

Chapin, J. P.

1939. The Birds of the Belgian Congo, Part II. Bulletin of the American Museum of Natural History, 75: vii +597 pages.

Clark, R. J.

1971. Wing-Loading-A Plea for Consistency in Usage. Auk, 88:927-928.

Daly, R. A.

1927. The Geology of Saint Helena Island. Proceedings of the American Academy of Arts and Sciences, 62: 31-92.

Darwin, C.

1844. Geological Observations on the Volcanic Islands Visited During the V'oyage of the H. M. S. Beagle. 175 pages. London: Smith, Elder and Company.

Decelle, J.

1970. Végétation. In La Faune terrestre de l'Isle SainteHélène, primière partie. Musee Royal de l'Afrique Central-Tervuren, Belgique-Annales Serie $I N-8^{\circ}$, Sciences Zoologiques, 181:37-44.

Falla, R. A.

1942. Review of the Smaller Pacific Forms of Pterodroma and Cookilaria. Emu, 42:111-118.

Fleet, R. R.

1972. Nesting Success of the Red-tailed Tropicbird on Kure Atoll. Auk, 89:651-659.

Foster, W., editor

1905. The Journal of John Jordain, 1608-1617, Describing His Experiences in Arabia, India, and the Malay Archipelago. Hakluyt Society: Series II, number 16, 394 pages. London.

1940. The Voyages of Sir James Lancaster to Brazil and the East Indies 1591-1603. New edition, Hakluyt Society: Series II, number 85,178 pages. London.

Gosse, $\mathbf{P}$.

1938. St. Helena, 1502-1938. xiv +447 pages. London: Cassell and Company.

Gray, A., editor

1890. The Voyage of Francois Pyrard of Laval to the East Indies, the Maldives, the Moluccas and Brazil. Hakluyt Society: Series I, number 80,572 pages. London.

Hagen, Y.

1952. Birds of Tristan da Cunha. Results of the Norwegian Scientific Expedition to Tristan da Cunha 1937-1938, 20:1-248.

Hare, P. E.

1969. Geochemistry of Proteins, Peptides, and Amino Acids. In G. Eglinton and M. Murphy, editors, Organic Chemistry. Berlin, Heidelberg, New York: Springer Verlag. 
Harris, M. P.

1969. Food as a Factor Controlling the Brecding of Puffinus lherminieri. Ibis, 111:139-156.

Haydock, E. L.

1954. A Survey of the Birds of St. Helena Island. Ostrich, 25:62-75.

Hays, J. D., and A. Peruzza

1972. The Significance of Calcium Carbonate Oscillations in Eastern Equatorial Atlantic Deep-sea Sediments for the End of the Holocene Warm Interval. Quatemary Research, 2:355-362.

Howard, $\mathbf{H}$.

1929. Avifauna of the Emcryville Shellmound. University of California Prblications in Zoology, 32:301-394.

Hutchinson, G. E.

1950. Survey of Contemporary Knowledge of Biogeochemistry, 3: The Biogeochemistry of Vertebrate Excretion. Bulletin of the American Museum of Natural History, 96: xviii +554 pages.

Jouanin, C.

1955. Une nouvelle espece de Procellariide. L'Oisean et Revue Française d'Ornithologie, 25:155-161.

1970. Le Petrel Noir de Bourbon Pterodroma aterima Bonaparte. L'Oiseau et Revue Française d'Ornithologie, 40:48-68.

Jouanin, C., and P. Paulian

1960. Recherches sur des ossements d'oiseaux provenant de l'ile Nouvelle-Amstcrdam (Ocćan Indien). Proceedings of the XII International Ornithological Congress, Helsinki, 1:368-372.

Kepler, C. B.

1968. Polynesian Rat Predation on Nesting Laysan Albatrosses and Other Pacific Seabirds. Auk, 84:426-430.

Lambrecht, K.

1933. Handbuch der Palaeornithologie. $\mathrm{xix}+1024$ pages. Berlin: Gebriider Borntraeger.

Leleup, $\mathrm{N}$.

1970. Géographic et Climatologic. In La Faune terrestre de l'Islc Saintc-Hélènc, primière partie. Musee Royal de l'Afrique Central-Tervuren, BelgiqueAnnales Serie $I N-8^{\circ}$, Sciences Zoologiques, 181:7-22.

Lesson, R. P., and P. Garnot

1828. Zoology. Pages 361-743 in part 2 in volume 1 in L. I. Duperrey, editor, Voyage antour du monde, exécuté par ordie du Roi, sur la Corvette de Sa Majeste, La Coquille, pendanl les amnes 1822, 1823, 1824 et 1825. Paris: Arthus Bertrand.

Long, C., editor

1961. Biochemist's Handbook. 1192 pages. Princelon: D. Van Nostrand.

Markham, A. H., editor

1880. The Voyages and Works of John Datis the Natigalor. Hakluyt Society: Series I, number 59, 392 pages. London.

Markham, C. R., cditor

1877. The V'oyages of Sir James Lancaster, KI., to the East Indies, with Abstracts of Journals of Voyages to the East Indies, during the Seventecnth Century,
Preserved in the India Office. And the Voyage of Captain John Knight (1606), To Seek the NorthWest Passage. Hakluyt Society: Series I, number 56, 314 pagcs. London.

1911. Early Spanish Voyages to the Strait of Magellan. Hakluyt Society: Series II, number 38, 228 pages. London.

Melliss, J. C.

1870. Notes on the Birds of the Island of St. Helena. Ibis, new series, 6:97-101.

1875. St. Helena: A Physical, Historical and Topographical Description of the Island Including Its Geology, Fauna, Flora, and Meteorology. xiv +426 pages. London: L. Reeve and Company.

Muir, M. D., and I. Baker

1968. The Early Plioccne Flora of Saint Hclena. Palaeogeography', Palaeoclimatology, Palaeoecology, 5:251268.

Murphy, R. C.

1927. On Certain Forms of Puffinus assimilis and Its Allies. American Museum Novitates, 276:1-15.

1928. Birds Collected During the Whitney South Sea Expedition, IV. American Museum Novitates, 322: $1-5$.

1936. Oceanic Birds of South America. 2 volumes. xxii + 1245 pages. New York: American Museum of Natural History.

Murphy, R. C., and S. Irving

1951. A Review of the Frigate-petrels (Pelagodroma). American Museum Novitates, 1506:1-17.

Murphy, R. C., and J. M. Pennoyer

1952. Larger Petrels of the Genus Pterodroma. American Museum Novitales, 1580:1-43.

Oliver, P., editor

1891. The Voyage of François Leguat of Bresse to Rodriguez, Mauritius, Java, and the Cape of Good Hope. Hakluyt Society: Scrics I, number 83, volume 2, 433 pages. London.

Olson, S. L.

1973. Evolution of the Rails of the South Atlantic Islands (Aves: Rallidae). Smithsonian Contributions to Zoology, 152:1-53.

1975. Remarks on the Gencric Characters of Bulweria. Ibis.

In press. Additional Notes on Sub-fossil Bird Remains from Ascension Island. Ibis.

Olson, S. L., and J. Farrand, Jr.

In prep. Systematics of the Genus Gygis.

Olson, S. L., and A. Wetmore

In press. A Preliminary Survey of an Extensive MioPliocenc Marinc Avifauna from Lec Creek, North Carolina. Smithsonian Contributions to Paleobiol. ogy.

Parkin, D. W.

1974. Trade-winds cluning the Glacial Cycles. Proceedings of the Royal Society of London, series A, 337:73100 . 
Peters, J. L.

1934. Check-list of Birds of the World. Volume 2, xvii + 401 pages. Cambridge, Massachusetts: Harvard University Press.

Pitman, G. R. S.

1965. The Eggs and Nesting Habits of the St. Helena Sand-Plover Charadrius pecuarius sanctae-helenae (Harting). Bulletin of the British Ormithologists' Club, 85:121-129.

Poole, E. L.

1938. Weights and Wing Areas in North American Birds. Auk, 55:511-517.

Ribeiro, A. de M.

1919. A Fauna Vertebrada da Ilha da Trindade. Archivos do Museu Nacional do Rio de Janeiro, 22:171-194.

Seale, R. F.

1834. The Geognosy of the Island of St. Helena, Illustrated in a Series of Views, Plans and Sections; Accompanied with Explanatory Remarks and $\mathrm{Ob}$ servations. 25 pages. London: Ackermann and Company.

Sibley, F. G., and R. W. McFarlane

1968. Gulls in the Central Pacific. Pacific Science, 22: 314-321.

Sinclair, W. F., editor

1902. The Travels of Pedro Teixeira; with His "Kings of Harmuz," and Extracts from His "Kings of Persia." Hakluyt Society: Series II, number 9, 292 pages. London.

Stonehouse, B.

1960. Wideawake Island. The Story of the B. O. U. Cenlenary Expedition to Ascension. 224 pages. London: Hutchinson.

1962. Ascension Island and the British Ornithologists' Union Centenary Expedition 1957-1959. Ibis, 103b: 108-123.
1963. The Laying Dates of Some St. Helenian Sea-birds, 1958-59. Ibis, 103b:480-482.

Temple, R. G., editor

1914. The Travels of Peter Mundy in Europe and Asia, 1608-1667. Hakluyt Society: Series II, number 35, volume 2, 437 pages. London.

1919. The Tranels of Peler Mundy in Europe and Asia, 1608-1667. Hakluyt Society: Series II, number 46, volume 3, part 2, pages 317-577. London.

Temple, R. C., and L. M. Anstey, editors

1936. The Travels of Peler Mundy in Europe and Asia, 1608-1667. Hakluyt Society: Series II, number 78, volume 5 , xxvii +226 pages. London.

Tiele, P. A., editor

1885. The Voyage of John Huygen van Linschoten to the East Indies from the Old English Translation of 1598. The First Book, Containing His Description of the East. Hakluyt Society: Series I, number 71, volume 2, 341 pages. London.

Vaurie, C.

1964. Systematic Notes on Palearctic Birds No. 53, Charadriidae: The Genera Charadrius and Pluvialis. American Museum Noritates, 2177:1-22.

Wallace, D. I. M,

1973. Sea-birds at Lagos and in the Gulf of Guinea. Ibis, 115:559-571.

Watson, G. E.

1966. Seabirds of the Tropical Allantic Ocean. 120 pages. Washington: Smithsonian Institution Press.

Wetmore, A.

1963. All Extinct Rail from the Island of St. Helena. Ibis, 1031 s:379-381.

Wollaston, T. V.

1878. Testacea Allantica or the Land and Freshwater Shells of the Azores, Madeiras, Salvages, Canaries, Cape Verdes, and Saint Helena. xi + 588 pages. London: L. Reeve and Company. 

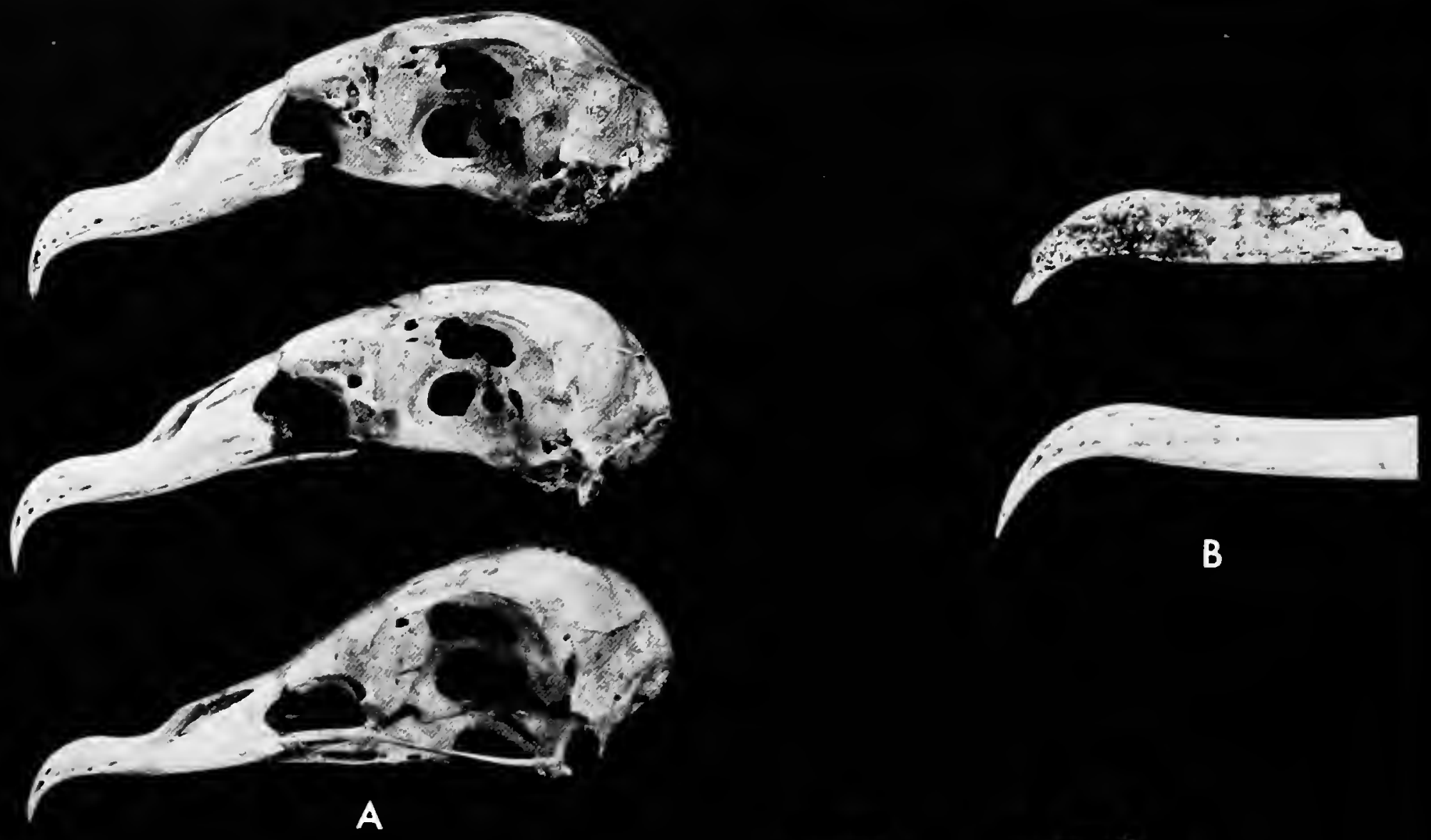

B

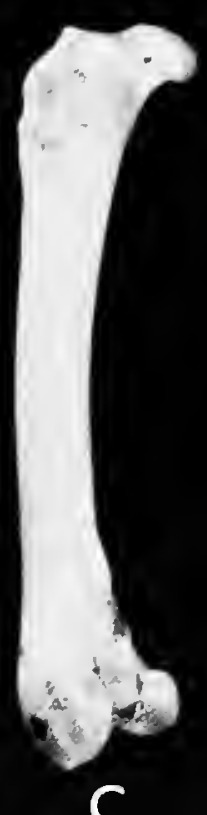

C

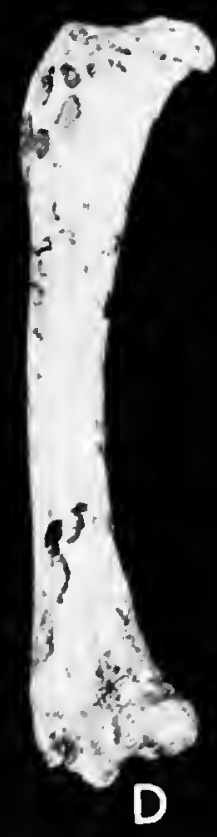

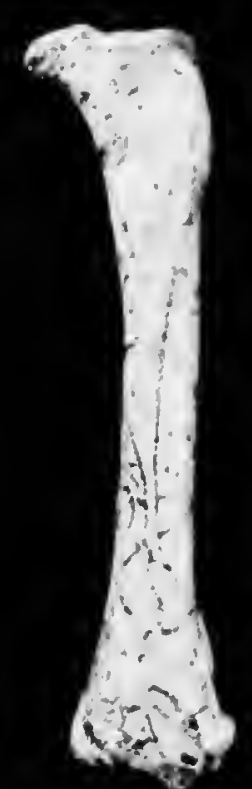

$\mathbf{E}$
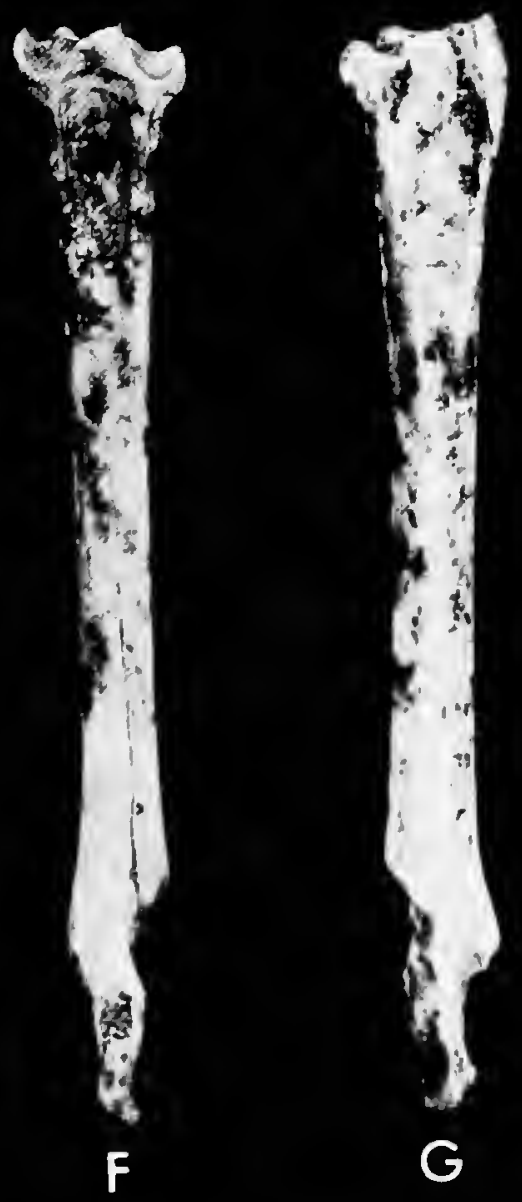

G

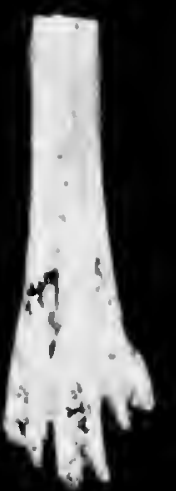

$\mathrm{H}$

PLate 1.-Skeletal elements of procellariids: A, Skulls of Pterodroma (top to bottom): P. rupinarum, new species (USNM 176593); P. rupinarum, new species (USNM 176594), holotype; P. mollis (AMNH 3118). B, Premaxillae of Puffinus (top to bottom): P. pacificoides, new species (USNM 175994); P. pacificus (USNM 497291). c, Femur of Puffinus pacificus (USNM 497921), posterior view. D, Femur of $P$. pacificoides, new species (USNM 175963), holotype, posterior view. E, Same, anterior view. F, Tarsometatarsus of $P$. pacificoides, new species (USNM 176004), anterior view. G, Same, posterior view. H, Distal end of tarsometatarsus of $P$. pacificoides, new species (USNM 176016), anterior view. (A is natural size and remaining figures are $\times 1.5$.) 


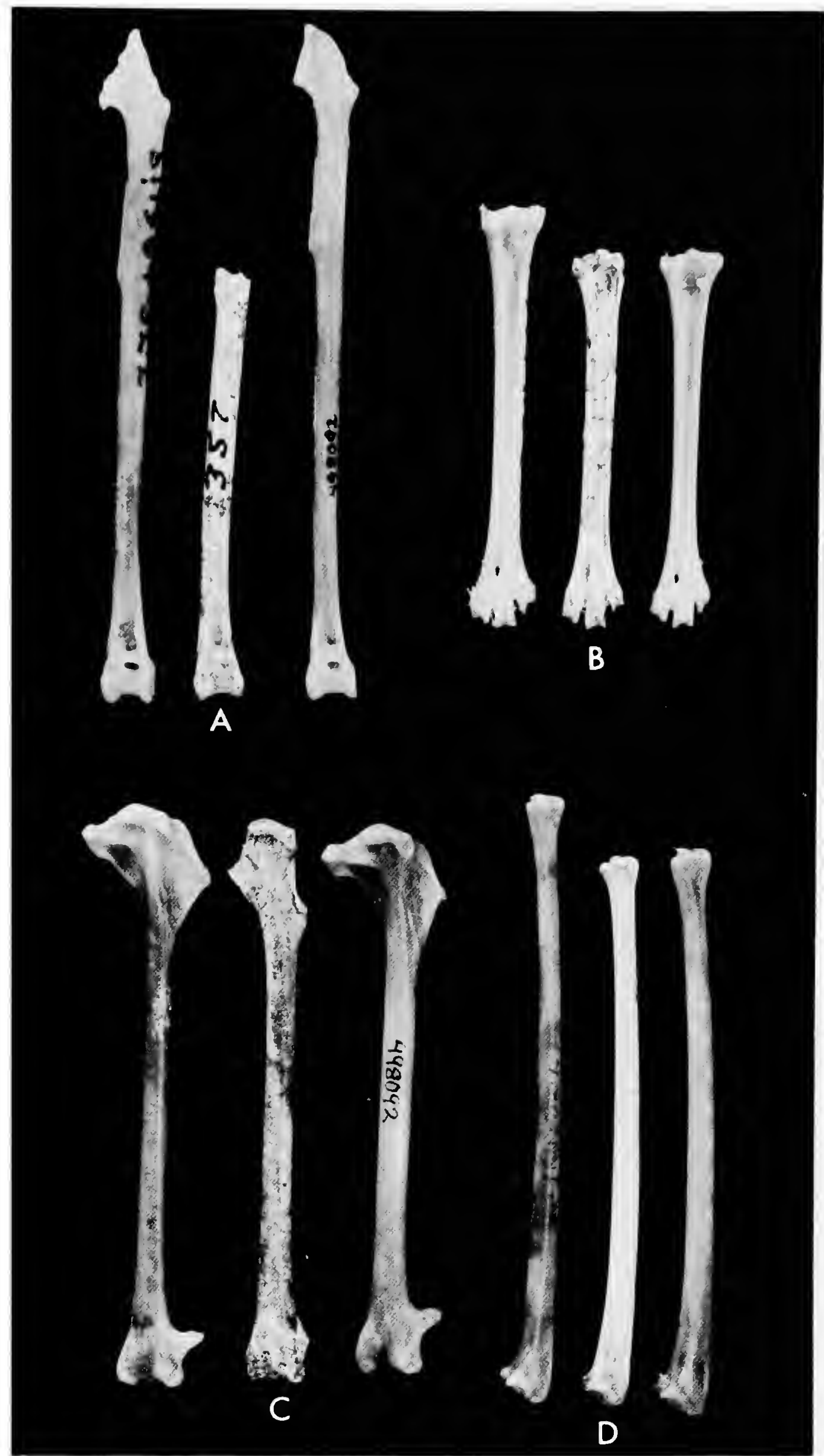

Plate 2.-Skeletal clements of Bulweria and Pterodroma (left, Bulweria fallax, BMNH S/ 1964.32.2; right, Pterodroma hypoleuca, USNM 498092; middle, Bulweria bifax, new specics): A, tibiotarsi (B. bifax, BMNH S/1963.25.8-Ashmole No. 357); 13, tarsometatarsi (B. bifax, USNM 176020), holotype; c, humcri (B. bifax, USNM 176148); D, ulnac (B. bifax, USNM 176202). A-B $\times 2$; C-D, natural size.) 


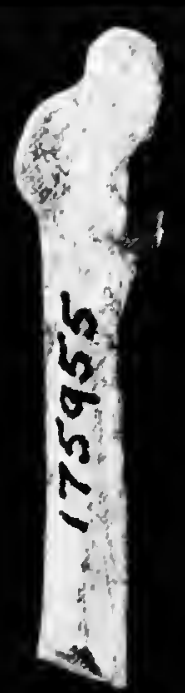

A

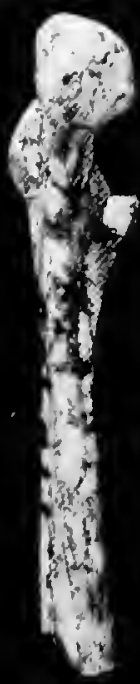

B

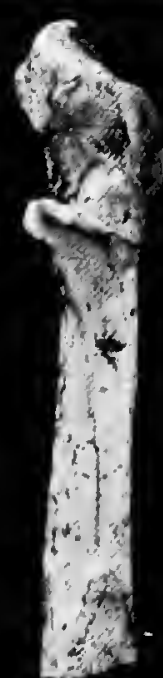

C

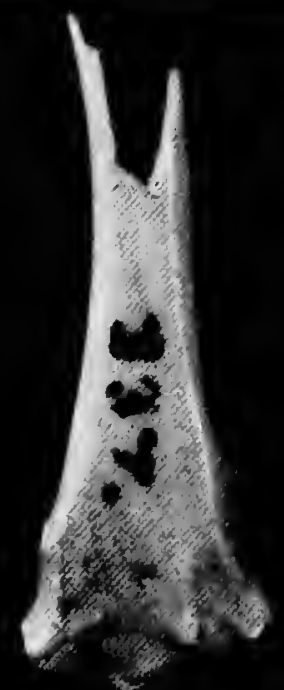

D

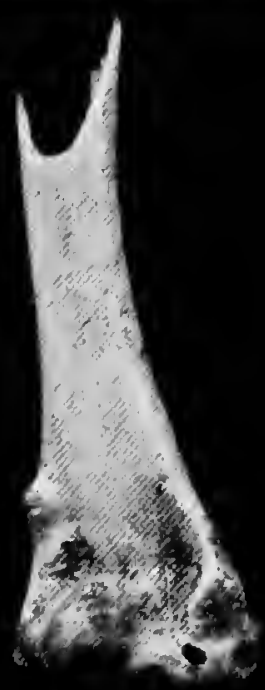

$E$
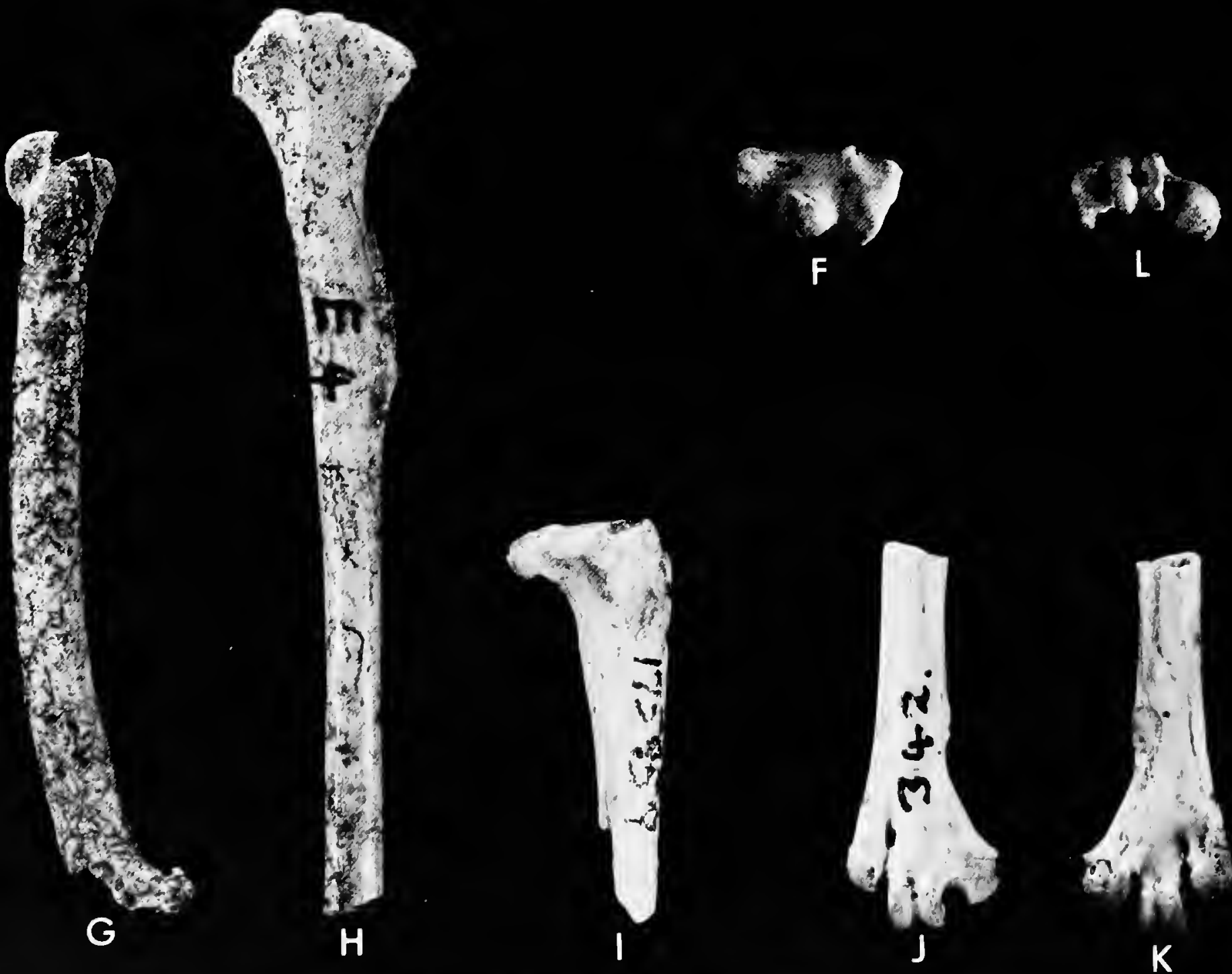

Plate 3.-Skeletal elements of Dysmoropelia dekarchiskos, new genus and species: A, right coracoid (USNM 175955), holotype, ventral view; B, same, internal view; c, same, dorsal view; D, left humerus (BMNH S/1963.25.29-Ashmole No. 337), anconal vicw; E, same, palmar vicw; F, same, distal view; G, left ulna (USNM 175956), external view; H, left tibiotarsus (BMNH S/1963.25.26-Kerr No. E4), anterior vicw; I, right femur (USNM 175959), posterior view; I, light tarsometatarsus (BMNH S/1963.25.28-Ashmolc No. 342), anterior view; $k$, same, posterior view; L, same, distal view. (All figures (wice natural size.) 


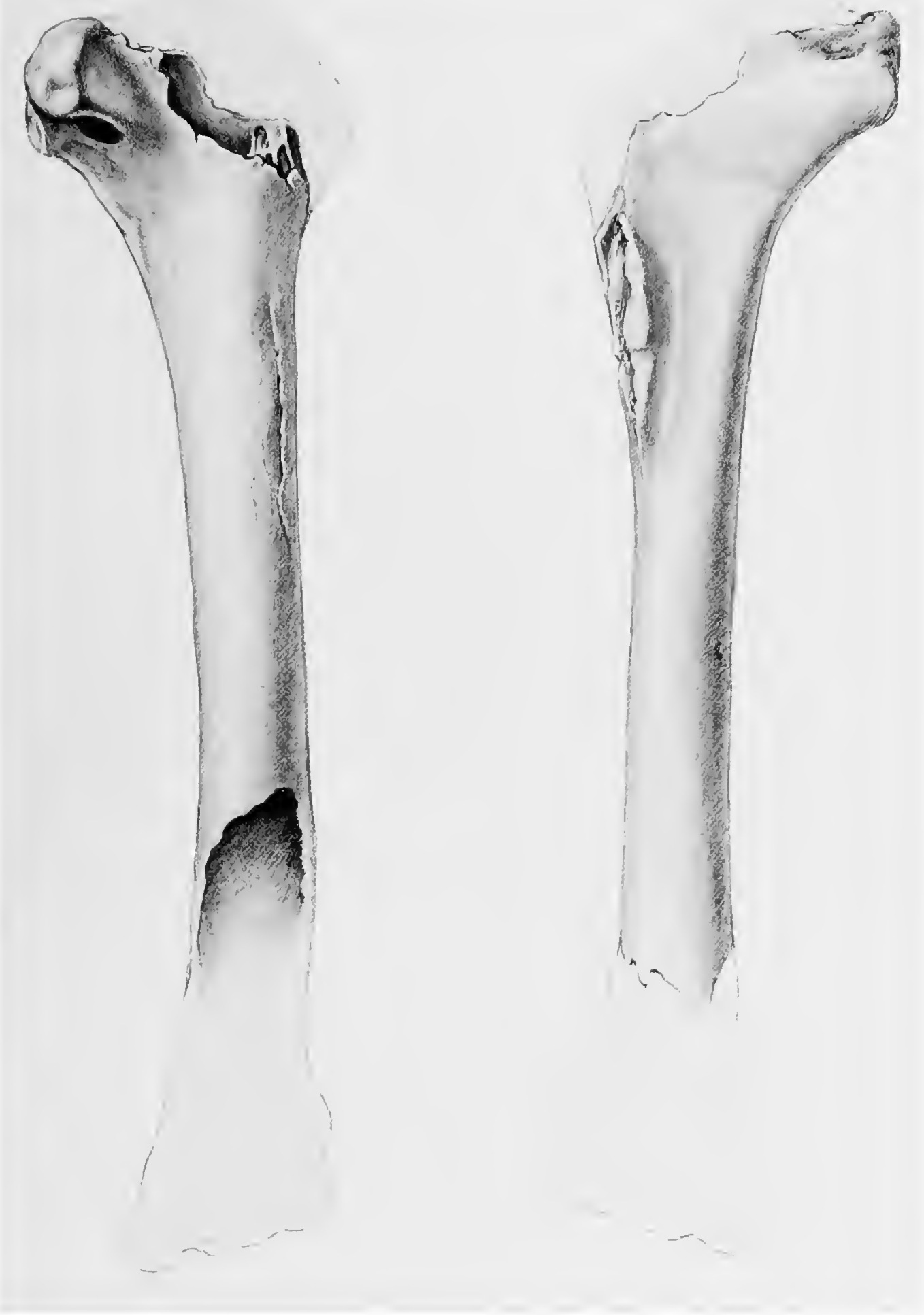

Plate 4.-Nannococcyx psix, new genus and species, holotype humerus (MCZ 7217). (Anconal view left, palmar view right; apploximately $\times 8$.) 


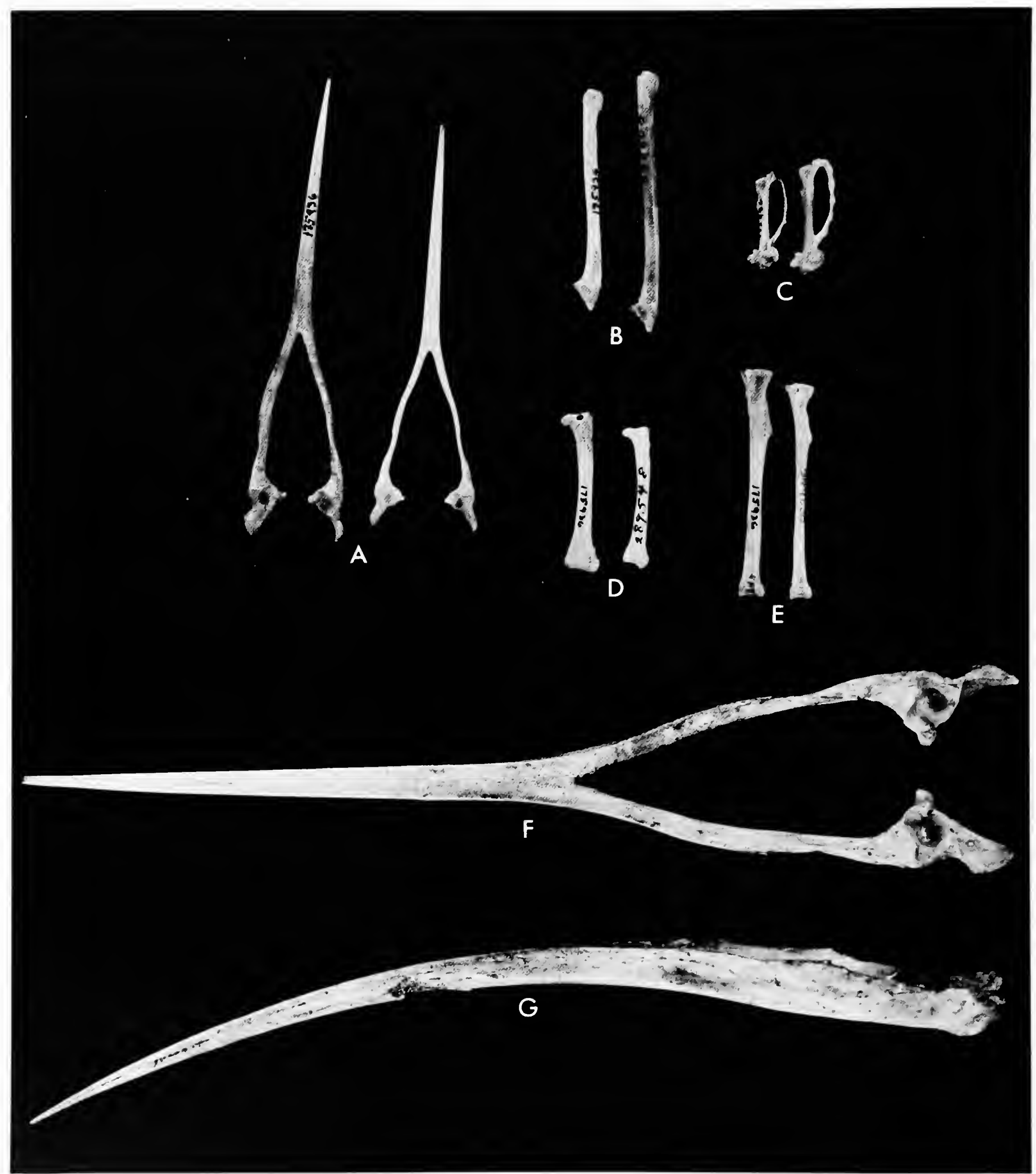

PLATF, 5.-Skcletal clements of Upupa antaios, new species (A-E, comparison of $U$. antaios, USNM 175936, holotype, on the left in each pair, with a large individual of $U$. epops, on the right in cach pair; natural sizc): A, mandibles; 1 , ulnac; C, carpomctacarpi; $D$, femora; $\mathrm{F}$, tibiotarsi; F, holotype mandible, dorsal view, twice natural size; c, same, lateral vicw. 

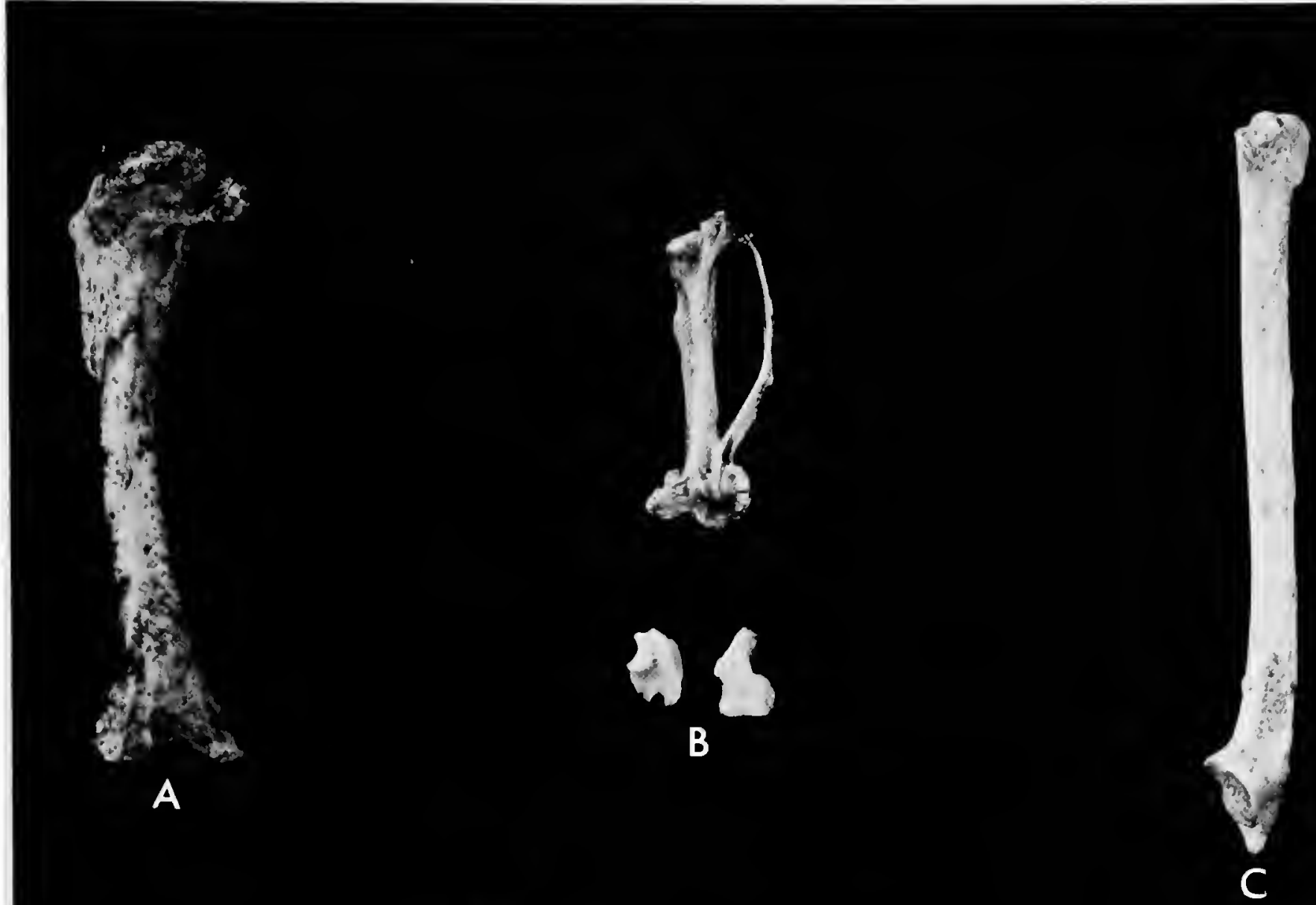

A
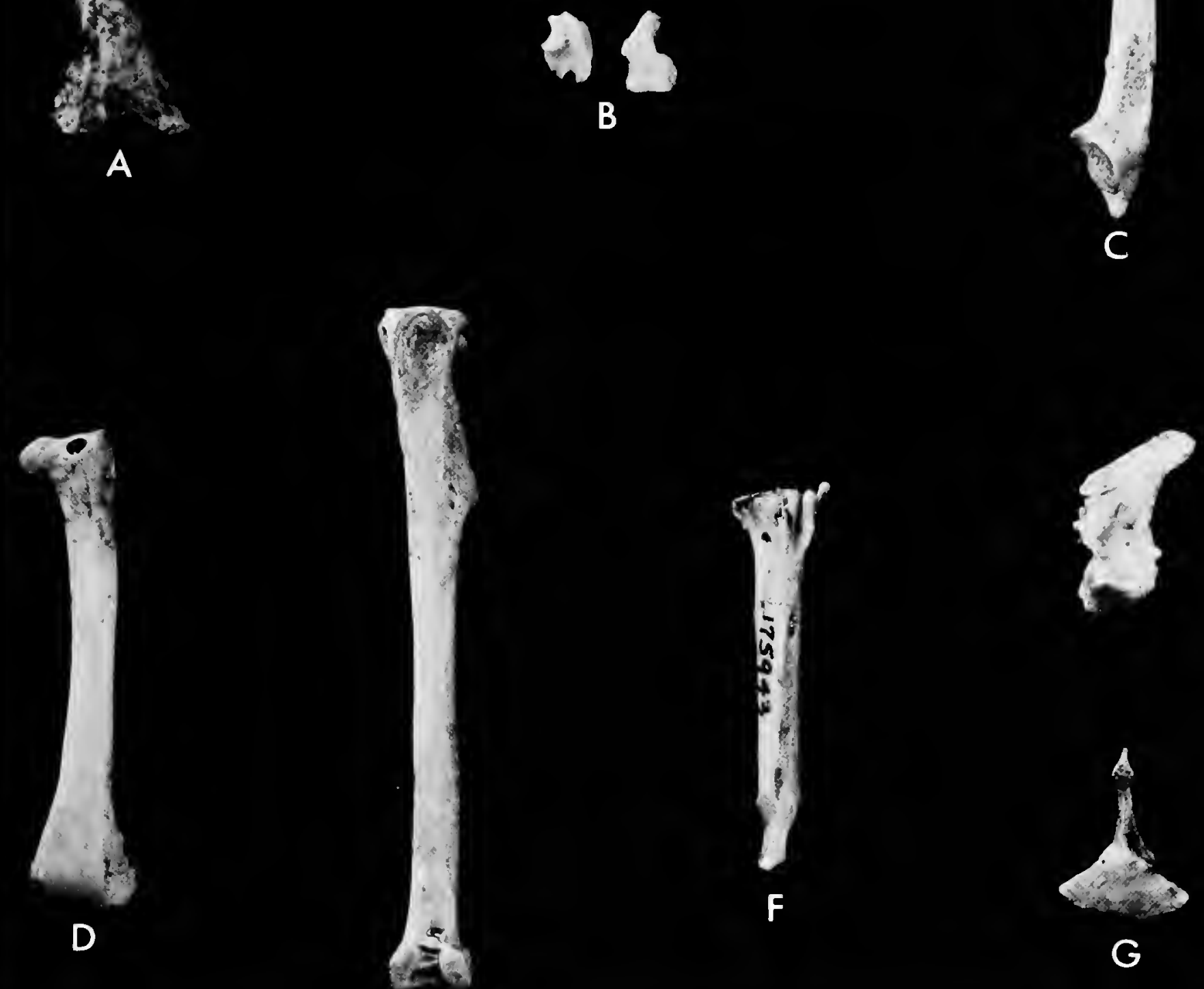

D

E

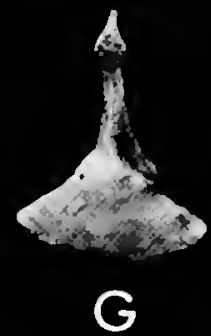

Plate 6.-Skeletal elements of Upupa antaios, new species, at twice natural size (all but a and F are from the holotype, USNM 175936): A, left humerus, anconal view (BMNH S/1963.25.18Ashmole No. 240); B, left carpometacarpus, radiale, and ulnare, internal view; c, left ulna, internal view; D, left femur, anterior view; F, left tibiotarsus, anterior view; F, right tarsometatarsus, posterior view (USNM 175943); c, pygostyle, left lateral view (above) and ventral view (below).

it U.S. GOVERNMENT PRINTING OFFICE: $1975-586.377 / 8$ 





\section{Publication in Smithsonian Contributions to Paleobiology}

Manuscripts for serial publications are accepted by the Smithsonian Institution Press, subject to substantive review, only through departments of the various Smithsonian museums. Non-Smithsonian authors should address inquiries to the appropriate department. If submission is invited, the following format requirements of the Press will govern the preparation of copy.

Copy must be typewritten, double-spaced, on one side of standard white bond paper, with $11 / 2$ " top and left margin, submitted in ribbon copy with a carbon or duplicate, and accompanied by the original artwork. Duplicate copies of all material, including illustrations, should be retained by the author. There may be several paragraphs to a page, but each page should begin with a new paragraph. Number consecutively all pages, including title page, abstract, text, literature cited, legends, and tables. The minimum length is 30 pages, including typescript and illustrations.

The title should be complete and clear for easy indexing by abstracting services. Taxonomic titles will carry a final line indicating the higher categories to which the taxon is referable: "(Ammonoidea: Goniatitidae)." Include an abstract as an introductory part of the text. Identify the author on the first page of text with an unnumbered footnote that includes his professional mailing address. A table of contents is optional. An index, if required, may be supplied by the author when he returns page proof.

Two headings are used: (1) text heads (boldface in print) for major sections and chapters and (2) paragraph sideheads (caps and small caps in print) for subdivisions. Further headings may be worked out with the editor.

In taxonomic keys, number only the first item of each couplet; if there is only one couplet, omit the number. For easy reference, number also the taxa and their corresponding headings throughout the text; do not incorporate page references in the key.

In synonymy, use the short form (taxon, author, date:page) with a full reference at the end of the paper under "Literature Cited." Begin each taxon at the left margin with subsequent lines indented about three spaces. Within an entry, use a period-dash (.-) to separate each reference. Enclose with square brackets any annotation in, or at the end of, the entry. For references within the text, use the author-date system: "(Jones, 1910)" and "Jones (1910)." If the reference is expanded, abbreviate the data: "Jones (1910:122, pl. 20: fig. 1)."

Simple tabulations in the text (e.g., columns of data) may carry headings or not, but they should not contain rules. Formal tables must be submitted as pages separate from the text, and each table, no matter how large, should be pasted up as a single sheet of copy.

Use the metric system instead of, or in addition to, the English system.

Illustrations (line drawings, maps, photographs, shaded drawings) can be intermixed throughout the printed text. They will be termed Figures and should be numbered consecutively; however, if a group of figures is treated as a single figure, the components should be indicated by lowercase italic letters on the illustration, in the legend, and in text references: "Figure 9b." If illustrations (usually tone photographs) are printed separately from the text as full pages on a different stock of paper, they will be termed Plates, and individual components should be lettered (Plate $9 b$ ) but may be numbered (Plate 9: figure 2). Never combine the numbering system of text illustrations with that of plate illustrations. Submit all legends on pages separate from the text and not attached to the artwork. An instruction booklet for the preparation of illustrations is available from the Press on request.

In the bibliography (usually called "Literature Cited"), spell out book, journal, and article titles, using initial caps with all words except minor terms such as "and, of, the." For capitalization of titles in foreign languages, follow the national practice of each language. Underscore (for italics) book and journal titles. Use the colon-parentheses system for volume, number, and page citations: "10(2):5-9." Spell out such words as "figures," "plates," "pages."

For free copies of his own paper, a Smithsonian author should indicate his requirements on "Form 36" (submitted to the Press with the manuscript). A non-Smithsonian author will receive 50 free copies; order forms for quantities above this amount with instructions for payment will be supplied when page proof is forwarded. 
$y=2$

(10)

(7) knges

E. 2.

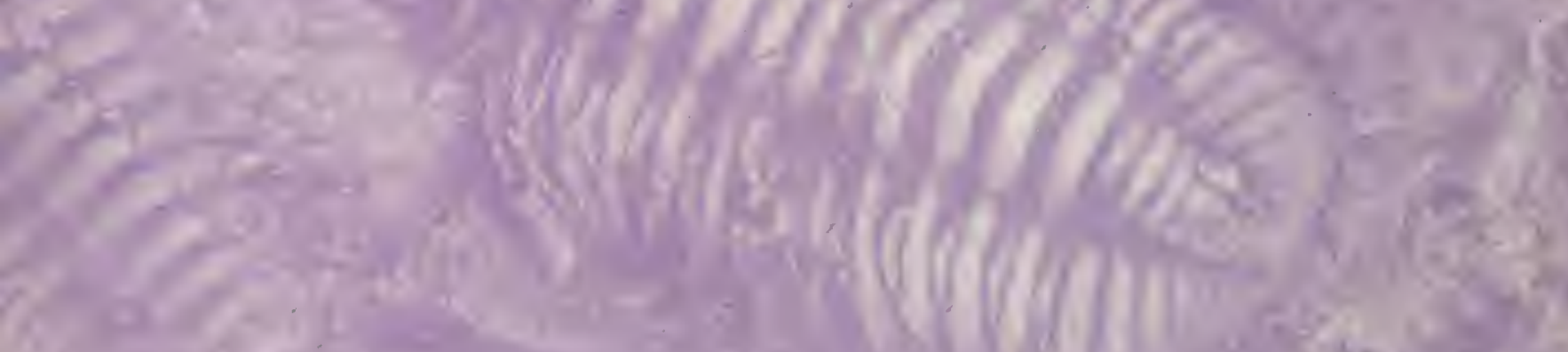
if wits

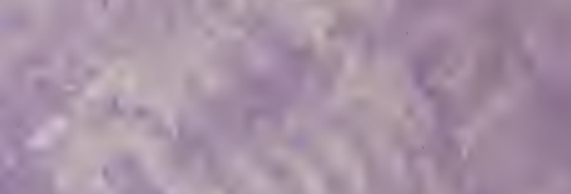

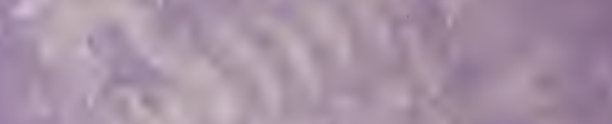

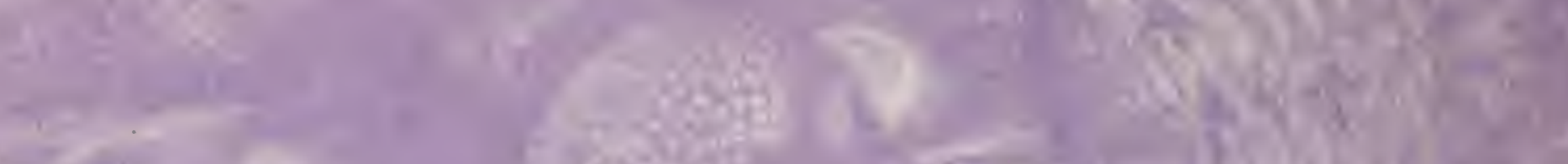

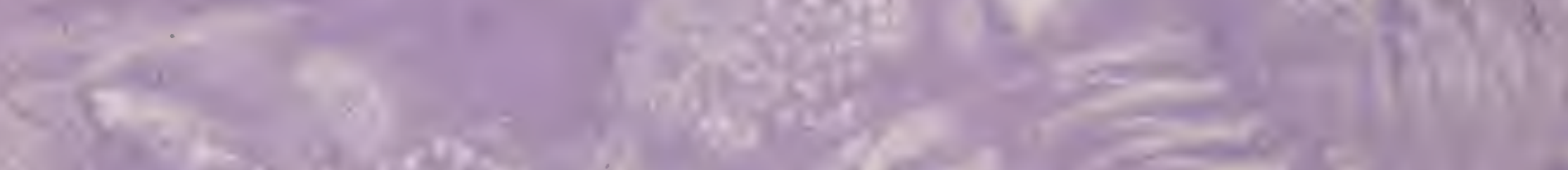

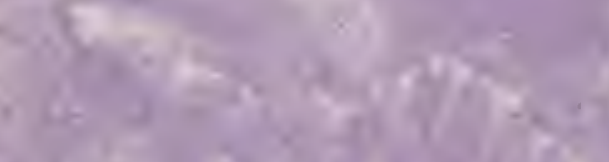

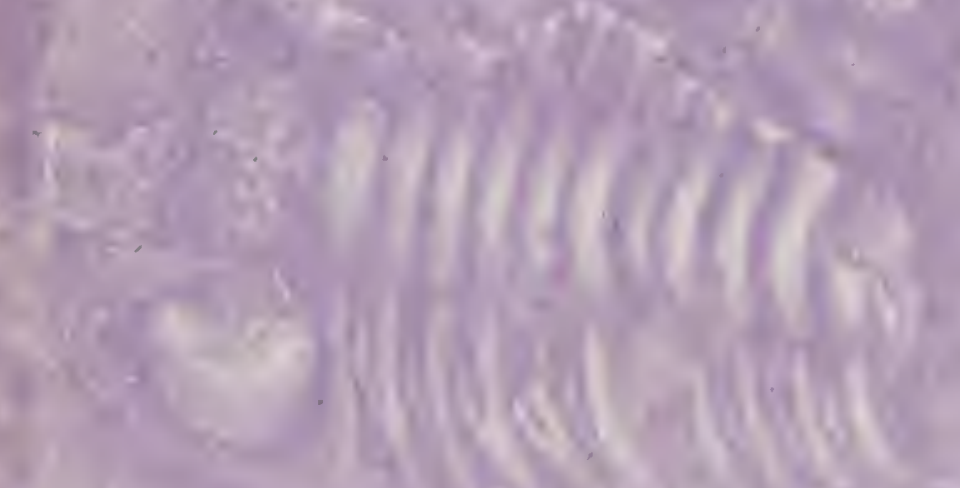

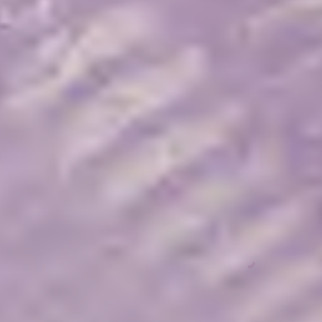

$\sum_{2 \pi}$ $2 x^{2}=x^{2}=3$

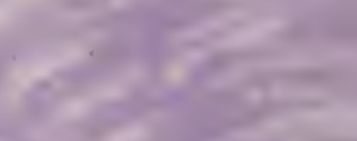

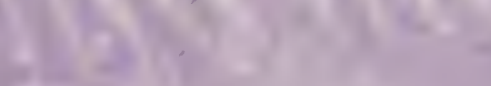

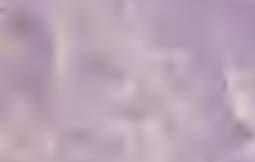

$\left(x-\frac{10}{10}\right.$

6

$187)^{2}$

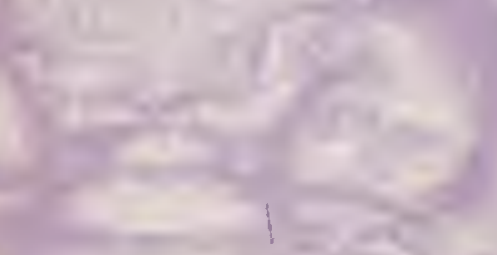

$-5=3$

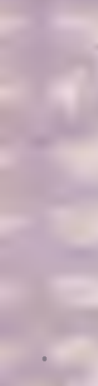

